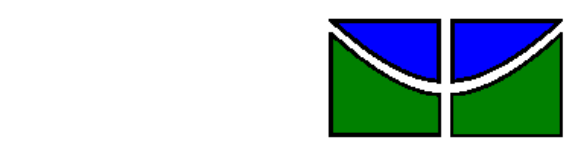

Universidade de Brasília

Faculdade de Economia, Administração e Contabilidade

Departamento de Administração

Curso de Graduação em Administração a distância

MARIA CLAUDIA OLIVEIRA LIMA

\title{
IMPACTO DO TREINAMENTO NO TRABALHO E SUPORTE ORGANIZACIONAL: um estudo de caso no Tribunal Regional Federal da 1르 Região
}

Brasília - DF 
MARIA CLAUDIA OLIVEIRA LIMA

\section{IMPACTO DO TREINAMENTO NO TRABALHO E SUPORTE ORGANIZACIONAL: um estudo de caso no Tribunal Regional Federal da 1ª Região}

Monografia apresentada a Universidade de Brasília (UnB) como requisito parcial para obtenção do grau de Bacharel em Administração.

Professora Orientadora: Mestre, Rose Mary Gonçalves

Brasília - DF 
Lima, Maria Claudia Oliveira.

Impacto do Treinamento no Trabalho e Suporte Organizacional: um estudo de caso no Tribunal Regional Federal da 1ㄹ Região / Maria Claudia Oliveira Lima. - Brasília, 2010.

$84 \mathrm{f}$. : il.

Monografia (bacharelado) - Universidade de Brasília, Departamento de Administração - EaD, 2010.

Orientador: Prof. Ms. Rose Mary Gonçalves, Departamento de Administração.

1. Avaliação de Treinamento. 2. Impacto do Treinamento no Trabalho. 3. Suporte Organizacional. I. Título 


\section{MARIA CLAUDIA OLIVEIRA LIMA}

\section{IMPACTO DO TREINAMENTO NO TRABALHO E SUPORTE ORGANIZACIONAL: um estudo de caso no Tribunal Regional Federal da 1ª Região}

A Comissão Examinadora, abaixo identificada, aprova o Trabalho de Conclusão do Curso de Administração da Universidade de Brasília da aluna

\section{Maria Claudia Oliveira Lima}

Mestre, Rose Mary Gonçalves

Professora-Orientadora

Doutora, Gisela Demo Fiuza, Professora-Examinadora
Titulação, nome completo Professor-Examinador 
Este trabalho é dedicado a minha família que sempre me apoiou em todos os momentos da minha vida. Em especial, decido este trabalho ao meu amado pai, Jaime, que não está conosco hoje, mas sei que, de algum lugar, encontra-se orgulhoso da sua filha. 


\section{AGRADECIMENTOS}

Agradeço a Deus que conspirou a meu favor me iluminando nos momentos mais difíceis da elaboração deste trabalho.

A minha amiga Verônica, companheira de curso e principal responsável pela minha formação em administração.

A minha querida mãe, Creusa, pela dedicação incondicional durante todos esses anos. Muito obrigada!

Ao amor da minha vida, Carlos, por todo apoio e incentivo, não me deixando desistir na reta final deste curso. Amo você!

À professora Rose Mary, minha orientadora, e às professoras supervisoras Juliana e Gisela pela atenção e auxílio em todas as etapas da elaboração desta monografia.

Por fim, agradeço às servidoras do TRF, Nádia e Simone, e aos participantes da pesquisa que colaboraram com este trabalho. 


\section{RESUMO}

O presente estudo teve por objetivo geral relacionar os construtos percepção de suporte organizacional e impacto do treinamento no trabalho na avaliação de dois cursos oferecidos pelo Tribunal Regional Federal da 1르 Região a seus servidores. Os objetivos específicos foram identificar se os servidores perceberam impacto no desempenho no cargo e avaliar a percepção de suporte organizacional. O tipo de pesquisa utilizado foi de natureza quantitativa. Quanto aos fins pode ser considerada descritiva e explicativa e, em relação aos meios, de campo. A amostra foi composta por dois grupos divididos da seguinte forma: Grupo A, 20 servidores que realizaram - curso técnicas de segurança para autoridades; e Grupo B, 37 servidores participantes do curso sistemas GPD e G-DOC. Foram utilizados dois instrumentos de pesquisa cientificamente validados, a saber: escala de Impacto do Treinamento no Trabalho (IMPACT) e escala de Percepção de Suporte Organizacional. Os dados foram analisados com o auxílio de dois aplicativos o Microsoft Excel (Office 2007) e - Statistical Package for the Social Sciences (SPSS) 18.0. Através desses programas, foram calculadas medidas descritivas (média, desvios padrão e freqüência) e correlações de Pearson entre as variáveis do estudo. Nos resultados relativos ao impacto no desempenho no cargo, os dois grupos apresentaram impacto positivo, sendo que para o Grupo $A$ o impacto foi maior. Em relação à percepção de suporte organizacional, no que se refere à dimensão relativa às exigências e a carga de trabalho, a opinião da maioria dos servidores da amostra indica que as práticas adotadas pela organização estão próximas das suas expectativas. Já nos demais fatores, os resultados apontam para uma avaliação apenas razoável em relação às políticas adotadas pela organização no que concerne à gestão de desempenho, ao suporte material e às práticas de ascensão, promoção e salários. Por fim, no que diz respeito à relação entre percepção de suporte organizacional e impacto do treinamento no trabalho, foi encontrada correlação negativa entre a dimensão de suporte relativa à carga de trabalho e o impacto do treinamento no trabalho no Grupo B da amostra. Nos demais fatores, não foram observadas correlações significativas.

Palavras-chave: Avaliação de treinamento. Impacto do treinamento no trabalho. Suporte organizacional. 


\section{LISTA DE ILUSTRAÇÕES}

Figura 1: Modelo de Avaliação Integrado e Somativo - MAIS

.26

Figura 2: Representação esquemática dos componentes do Modelo de Avaliação do

Impacto do Treinamento no Trabalho - IMPACT ……...................................27 


\section{LISTA DE TABELAS}

Tabela 1: Impacto em amplitude - Grupo A .................................................... 41

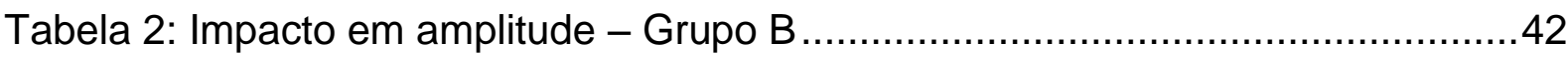

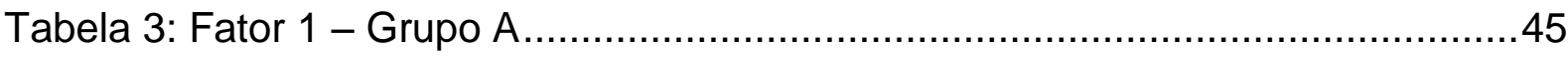

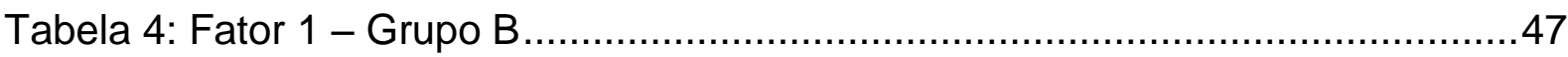

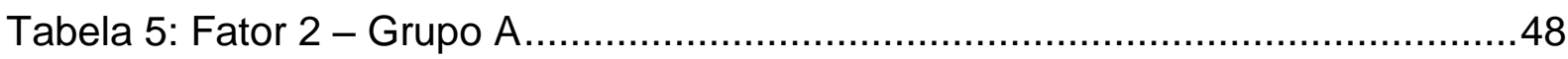

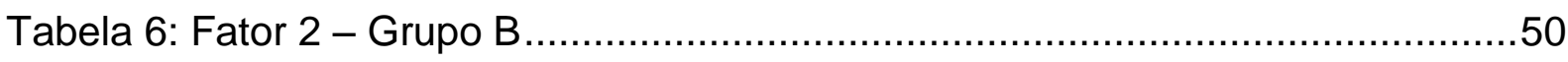

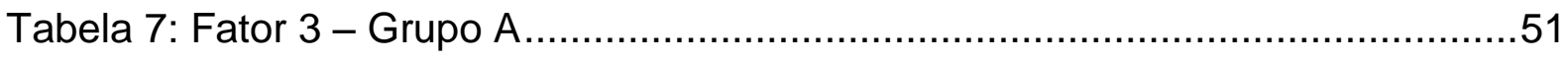

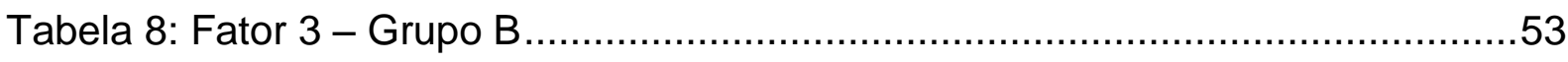

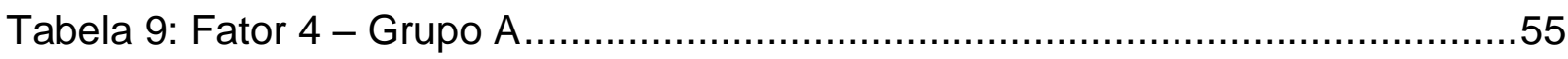

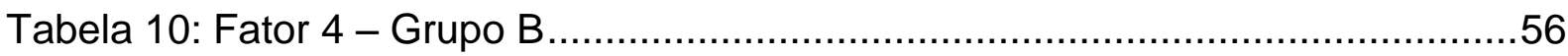

Tabela 11: Resumo dos resultados da avaliação de suporte - Grupo A.................58

Tabela 12: Resumo dos resultados da avaliação de suporte - Grupo B.................59

Tabela 13: Correlações entre os fatores de suporte e a medida de impacto ............61 


\section{LISTA DE QUADROS}

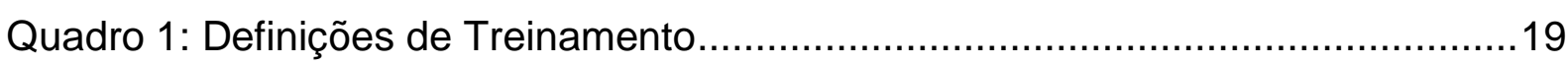

Quadro 2: Principais Resultados das Pesquisas Nacionais e Estrangeiras .............28

Quadro 3: Conceitos Relacionados a Suporte ........................................... 31

Quadro 4: Características da amostra - Grupo A ......................................... 35

Quadro 5: Características da amostra - Grupo B ........................................... 35

Quadro 6: Fatores, definições, quantidade de itens e índices de confiabilidade dos fatores da Escala de Percepção de Suporte Organizacional ...........................38 


\section{LISTA DE ABREVIATURAS E SIGLAS}

IMPACT - Modelo de Avaliação do Impacto do Treinamento no Trabalho

SPSS - Statistical Package for the Social Sciences

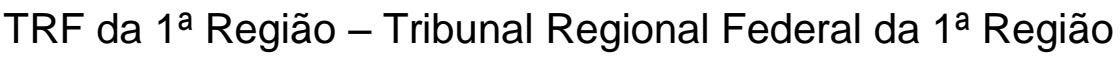




\section{SUMÁRIO}

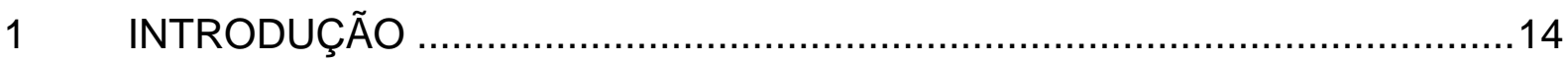

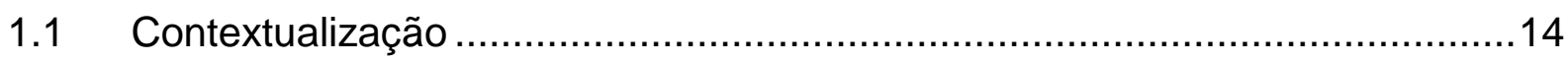

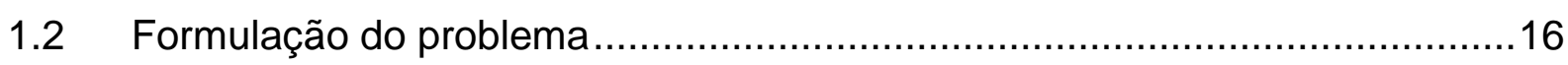

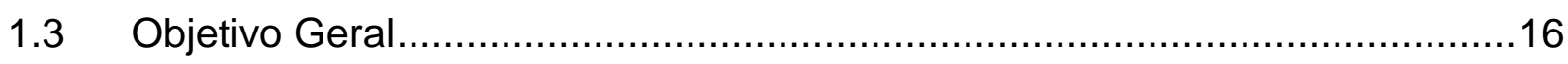

1.4 Objetivos Específicos ...................................................................16

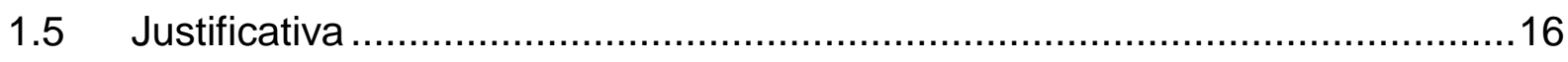

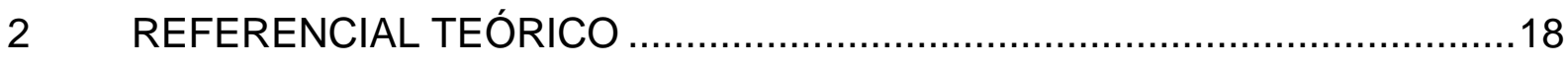

2.1 Treinamento, Desenvolvimento e Educação …………………………....18

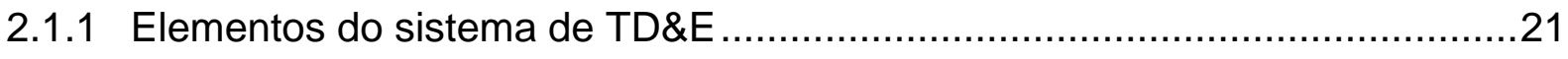

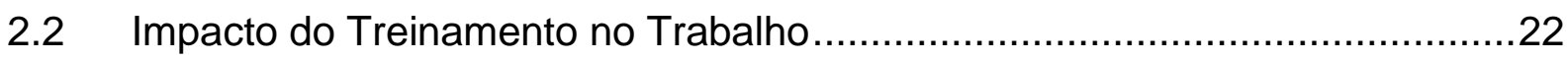

2.2.1 Importância da mensuração de impacto de TD\&E ......................................24

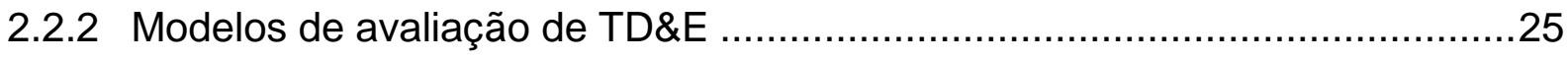

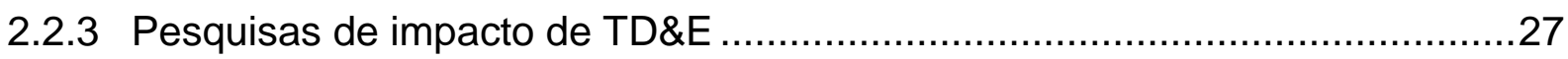

2.3 Suporte Organizacional: conceito e pesquisas ..........................................30

3 MÉTODOS E TÉCNICAS DE PESQUISA ...................................................3

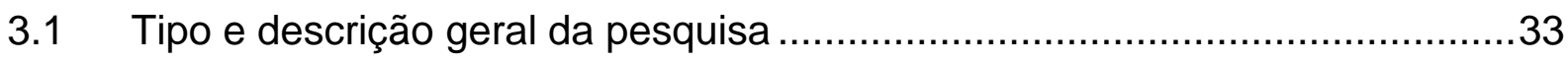

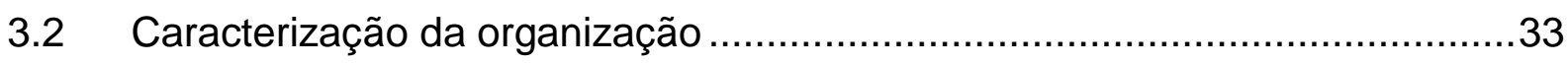

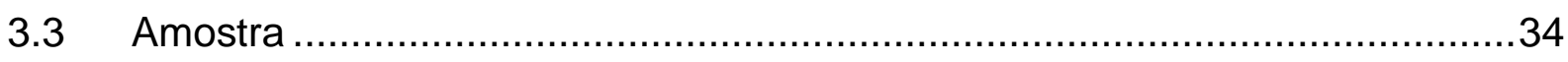

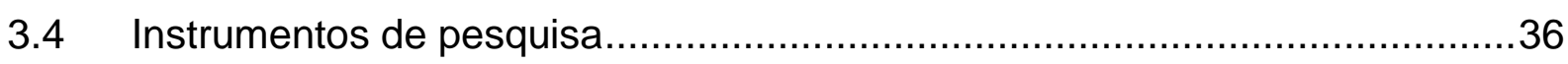

3.5 Procedimentos de coleta e de análise de dados ..........................................38

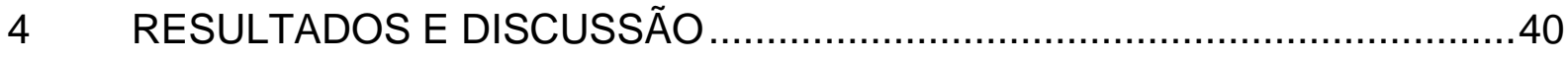

4.1 Resultados descritivos do impacto do treinamento no trabalho......................40

4.2 Avaliação de Percepção de Suporte Organizacional....................................44

4.2.1 Fator 1: Gestão de desempenho ……...................................................... 45

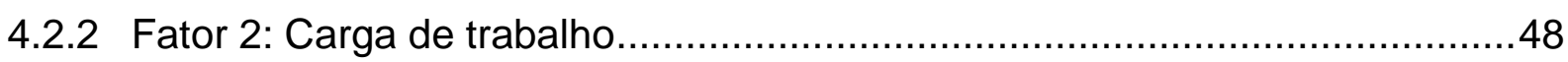

4.2.3 Fator 3: Suporte material ..................................................................... 
4.2.4 Fator 4: Práticas organizacionais de ascensão, promoção e salários .55

4.2.5 Resumo dos principais resultados da avaliação de suporte .58

4.3 Relações entre as variáveis em estudo ..............................................60

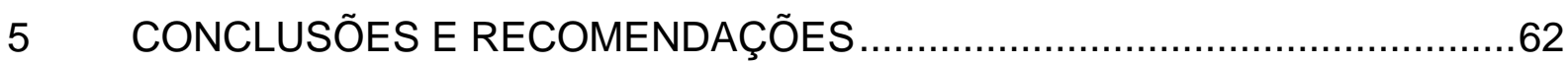

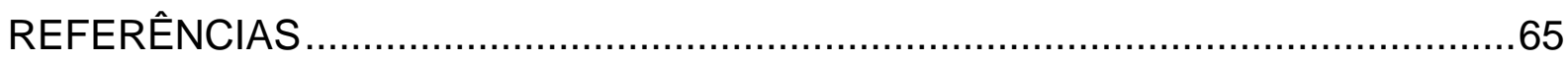

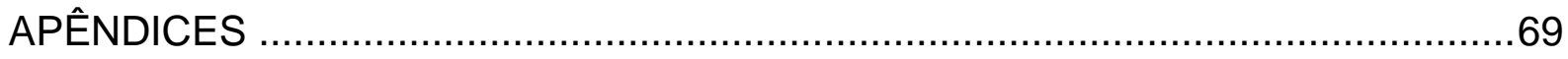

Apêndice A - Questionário Perfil do Participante da Pesquisa ............................70

Apêndice B - Resultados Descritivos da Avaliação de Suporte Organizacional Técnicas de Segurança para Autoridades...................................71

Apêndice C - Resultados Descritivos da Avaliação de Suporte Organizacional Sistemas GPD e G-DOC .................................................... 74

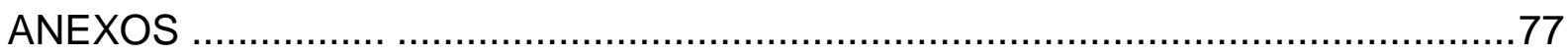

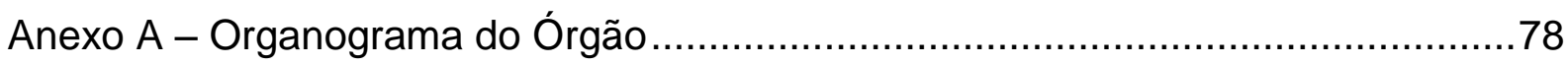

Anexo B - Orientação Geral aos Participantes da Pesquisa..................................79

Anexo C - Questionário de Impacto do Treinamento no Trabalho........................80

Anexo D - Questionário de Percepção de Suporte Organizacional ........................81 


\section{INTRODUÇÃO}

Este capítulo, no qual será realizada a introdução do assunto abordado na pesquisa, está dividido em cinco partes, a saber: contextualização do assunto, formulação do problema, objetivo geral, objetivos específicos e justificativa.

\subsection{Contextualização}

No cenário atual, com a globalização e o rápido avanço tecnológico que provocam constantes mudanças na área dos negócios, as organizações públicas e privadas precisam, constantemente, repensar e realinhar as suas práticas de gestão as suas estratégias visando garantir sua adaptabilidade, de forma a alcançar seus resultados nesse ambiente instável no qual estão inseridas.

Assim, para as organizações e seus funcionários enfrentarem esse mercado global, as constantes inovações tecnológicas e a reorganização contínua no ambiente de negócios é necessário que tenham um desempenho de qualidade. Dessa forma, os trabalhadores, que antes se especializavam em apenas uma tarefa repetitiva e limitada, precisam pensar e agir em níveis mais altos (MEISTER, 1999).

Diante dessa demanda por trabalhadores mais qualificados, as ações de treinamento, desenvolvimento e educação (TD\&E) ganharam destaque passando a ocupar um dos papéis centrais na área de gestão de pessoas nas organizações. Os impactos dessas ações segundo Bastos (2006, p. 23):

[...] são fundamentais tanto para os ajustes entre indivíduo-trabalho que se traduzem em diferenças de desempenho individuais e coletivos quanto para as relações entre organizações e seus contextos, garantindo-Ihes, ou não, produtividade e competitividade.

As ações de TD\&E visam preparar os indivíduos e assim torná-los mais competentes para o desempenho no trabalho, pois, é a partir dessas ações que as habilidades motoras, cognitivas e afetivas (destacando-se as habilidades relacionais, interativas 
e interpessoais) podem ser desenvolvidas, portanto, observa-se uma relação estreita entre ações de TD\&E e desempenho no trabalho (GONDIM et al., 2006).

Nesse sentido, Freitas et al. (2006, p. 489) afirmam que "mensurar o impacto de TD\&E significa avaliar em que medida os esforços despendidos nessas ações de TD\&E efetivamente geraram os efeitos desejados".

A avaliação seria um processo que envolve sempre algum tipo de coleta de dados e com base na análise das informações obtidas é possível emitir um juízo de valor a respeito de um treinamento, ou um conjunto de treinamentos (BORGES-ANDRADE, 2002).

$\mathrm{Na}$ literatura brasileira existem diversos modelos de avaliação de treinamento como o Modelo de Avaliação Integrado e Somativo (MAIS) de Borges-Andrade (1982 apud BORGES-ANDRADE, 2006a) e o Modelo Integrado de Avaliação do Impacto do Treinamento no Trabalho (IMPACT) desenvolvido por Abbad (1999). No entanto, apesar da existência de diversos métodos, percebe-se que, no dia-a-dia das organizações, há pouca preocupação em colocá-los em prática (GONDIM et al., 2006).

Os eventos instrucionais em organizações e trabalho (O\&T) são situações sistematicamente planejadas com o objetivo de proporcionar ao aprendiz condições externas adequadas à aquisição, retenção, transferência de novas aprendizagens para o trabalho. No entanto, para que tal processo ocorra de maneira satisfatória, além das situações de aprendizagem criadas pelas ações de TD\&E, será necessário que os conhecimentos, habilidades e atitudes (CHAs) do participante, vistos como desempenhos no trabalho, recebam apoio da organização para que ocorram e sejam aplicados nos ambientes de trabalho (ABBAD et al., 2006).

Diante disso, o suporte organizacional à aplicação dos novos CHAs no trabalho é condição necessária, embora não suficiente, à aplicação de novas aprendizagens, isso porque a ação de treinamento, apenas, não é capaz de garantir a aplicação das novas aprendizagens no trabalho (ABBAD et al., 2006).

O presente estudo destina-se a analisar possíveis relações entre suporte organizacional e impacto do treinamento no trabalho na avaliação de dois cursos oferecidos pelo Tribunal Regional Federal da 1를 Região - TRF da 1를 Região - a seus servidores. 


\subsection{Formulação do problema}

Diante do contexto apresentado, pergunta-se: Há relação entre a percepção de suporte organizacional e o impacto no desempenho no cargo dos treinados do curso segurança para autoridades e dos treinandos do curso sistemas GPD e G-DOC servidores do Tribunal Regional Federal da $1^{\underline{a}}$ Região?

\subsection{Objetivo Geral}

- Relacionar a percepção de suporte organizacional e o impacto do curso técnicas de segurança para autoridades e do curso sistemas GPD e G-DOC.

\subsection{Objetivos Específicos}

- Avaliar o impacto no desempenho no cargo dos treinandos;

- Avaliar a percepção de suporte organizacional.

\subsection{Justificativa}

Nos últimos anos as organizações aumentaram significativamente o investimento em ações voltadas para o treinamento, desenvolvimento e educação das pessoas no trabalho (TD\&E).

Embora o número de ações de TD\&E tenha aumentado significativamente, a real efetividade dessas práticas, até então, é pouco conhecida por parte das organizações, que ainda não se preocupam em desenvolver e aplicar mecanismos que permitam avaliar se os objetivos propostos pelas ações foram ou não alcançados e, consequentemente, os motivos do sucesso ou fracasso de determinada prática. 
O estudo proposto, através da avaliação de dois cursos oferecidos pelo TRF da $1^{\text {a }}$ Região a seus servidores, busca avaliar o impacto do treinamento no trabalho e a percepção de suporte organizacional e, a partir desses resultados, relacionar essas variáveis no intuito de identificar possíveis relações entre elas.

A relevância da pesquisa para o meio acadêmico, para as organizações e para a sociedade é apresentada a seguir.

Para a academia, a referida pesquisa poderá contribuir para aprimorar e desenvolver conhecimento sobre esse assunto.

A contribuição para a organização, objeto de estudo, reside no fato de poder trazer informações do ponto de vista dos participantes a respeito do curso ministrado, de possíveis entraves à transferência do aprendido bem como de prováveis impactos do curso no desempenho no cargo desses servidores. Com base nesses resultados o órgão terá a oportunidade de avaliar o curso e, caso necessário, aperfeiçoá-lo.

Para outras organizações, a pesquisa poderá servir como um alerta, pois não basta somente investir em ações de TD\&E, é fundamental que haja mecanismos que permitam avaliar tais práticas.

Em relação à sociedade, a formação efetiva de servidores públicos pode colaborar para um serviço público célere e eficiente, portanto, a sociedade é parte interessada em verificar se ações que visam preparar os servidores públicos para o bom desempenho no cargo estão obtendo resultados satisfatórios ou não. 


\title{
2 REFERENCIAL TEÓRICO
}

Neste capítulo será apresentada a fundamentação teórica do presente trabalho. A primeira parte traz os conceitos e os elementos do sistema de TD\&E. A segunda, o conceito de impacto do treinamento no trabalho, a importância da sua mensuração, modelos de avaliação de treinamento e as pesquisas nessa área. Por fim, a terceira parte engloba o conceito e pesquisas relativos a suporte organizacional.

\subsection{Treinamento, Desenvolvimento e Educação}

A área de TD\&E, não fugindo a regra das ciências sócio-comportamentais, encontrase envolta em uma série de problemas conceituais. Pelo menos quatro conceitos amplamente utilizados na área são normalmente diferenciados nas tentativas empreendidas por alguns autores de imprimir-Ihes maior precisão conceitual, são eles: instrução, treinamento, desenvolvimento e educação (BASTOS, 1991). A seguir serão apresentadas algumas definições desses conceitos na literatura.

Instrução é o processo que requer definição de objetivos específicos e métodos de ensino antes do início do processo de aprendizagem. Portanto, instrução seria parte ou parcela da educação e, também, parte (a grande parte, segundo o autor) do treinamento, embora esses dois processos não sejam objeto de clara demarcação no ambiente do trabalho (ROMISZOWISKI, 1978 apud BASTOS, 1991).

Vargas e Abbad (2006, p. 139), ampliam o escopo do conceito de instrução proposto por Romiszowiski definindo-a como:

\begin{abstract}
uma forma mais simples de estruturação de eventos de aprendizagem que envolve definição de objetivos e aplicação de procedimentos instrucionais. É utilizada para transmissão de conhecimentos, habilidades e atitudes simples por intermédio de eventos de curta duração como aulas e similares. Os materiais podem assumir a forma de cartilhas, manuais, roteiros, etc., podem, em alguns casos, serem auto-instrucionais.
\end{abstract}

Pontual (1978 apud BASTOS, 1991, p. 88), já havia ampliado o conceito de instrução proposto por Romiszowiski, com base em definições estabelecidas na 
década de 50 pelo Congresso Internacional de Ciências Administrativas: "a instrução é o vocábulo usado para indicar os processos formais e institucionalizados através dos quais a educação é ministrada até a adoção de uma profissão". Bastos (1991) destaque que essa definição de instrução não tem o mesmo significado daquela proposta por Romiszowski, embora em ambas esteja presente a noção de algo intencionalmente planejado e ministrado.

Em relação ao conceito de treinamento, embora existam na literatura várias definições, observa-se que elas guardam grande coerência entre si (VARGAS; ABBAD, 2006). O Quadro 1 sumariza algumas dessas definições.

\section{DEFINIÇÕES DE TREINAMENTO}

\section{Autor}

Hinrichs (1976)

\section{Definição}

- "Treinamento pode ser definido como quaisquer procedimentos, de iniciativa organizacional, cujo objetivo é ampliar a aprendizagem entre os membros da organização."

- "Treinamento é aprendizagem para propiciar melhoria de desempenho no trabalho atual."

- "Treinamento é o esforço planejado pela organização para facilitar a aprendizagem de comportamentos relacionados com o trabalho por parte de seus empregados."

UK Department of Employment (1971, apud Latham 1988)

Goldstein (1991)
- "Treinamento é o desenvolvimento sistemático de padrões de comportamento, atitudes, conhecimento-habilidade, requeridos por um indivíduo, de forma a desempenhar adequadamente uma dada tarefa ou trabalho".

- "Treinamento é uma aquisição sistemática de atitudes, conceitos, conhecimentos, regras ou habilidades que resultem na melhoria do desempenho no trabalho".

Quadro 1: Definições de Treinamento

Fonte: Vargas; Abbad (2006, p. 140).

Bastos (1991), faz uma análise dos conceitos apresentados no Quadro 1. Segundo o autor, enquanto Wexley enfatiza a ação planejada da organização, Goldstein e Latham destacam o processo de aquisição/modificação de comportamentos dirigido para melhorar o desempenho no trabalho. Hinrichs (1976 apud BASTOS, 1991, p. 89) combina essas duas dimensões básicas oferecendo um exame bem mais detalhado do conceito destacando alguns aspectos complementares à sua definição:

a aprendizagem desejada deve contribuir para o atingimento dos objetivos organizacionais (ampliar a sua efetividade);

por aprendizagem deve-se entender o processo de mudança de comportamentos pela experiência (no caso, atividade de treinamento); 
a noção de treinamento deve ser entendida como um processo sistemático, intencionalmente conduzido pela organização;

comportamento deve ser visto como um rótulo geral incluindo, também, cognições e sentimentos, Como qualquer comportamento aprendido pode ser pensado como uma habilidade (skill), treinamento pode ser entendido como o processo de ampliar/desenvolver habilidades; no caso, aquelas que melhorem o nível de proficiência de uma determinada tarefa, sendo, normalmente, agrupadas em três categorias: motoras, cognitivas e interpessoais.

A definição proposta por Hinrichs fornece parâmetros importantes para pensar o conceito de treinamento e assim diferenciá-lo dos demais conceitos. No entanto, apesar de revelar-se ampliado ao incluir todas as possíveis modalidades de habilidades e quaisquer procedimentos de iniciativa da organização, a inclusão do critério de intencionalidade em produzir melhora do desempenho e o controle desse processo pela organização, acaba restringindo sua amplitude (BASTOS, 1991).

A expressão desenvolvimento de recursos humanos, segundo Nadler (1984 apud VARGAS; ABBAD, 2006), possui uma única e identificada função: refere-se à promoção de aprendizagem para empregados (ou não), visando ajudar a organização a alcançar os seus objetivos.

Para Nadler (1984 apud VARGAS; ABBAD, 2006, p. 142) desenvolvimento seria "aprendizagem voltada para o crescimento individual, sem relação com um trabalho específico".

Vargas (1996, p. 127), em uma conceituação mais ampla, agrupa os dois conceitos - treinamento e desenvolvimento. Para a autora:

treinamento e desenvolvimento são a aquisição sistemática de conhecimentos capazes de provocar, a curto ou longo prazo, uma mudança na maneira de ser e de pensar do indivíduo, através da internalização de novos conceitos, valores ou normas e da aprendizagem de novas habilidades.

Segundo Borges-Andrade (2002, p. 32), “[...], treinamento e desenvolvimento (T\&D) parecem estar intimamente relacionados e seus conceitos podem estar perdendo as claras fronteiras que os separavam há menos de duas décadas". O autor explica que noções que pareciam mais restritas ao conceito de Treinamento como sistematização, tecnologia e intencionalidade, podem ser sorvidas pelo conceito de Desenvolvimento, quando esse é posto em prática como estratégia organizacional. 
Em relação a todos os conceitos analisados anteriormente, educação pode ser considerado uma das formas mais amplas de aprendizagem, com um escopo que extrapola o contexto específico do ambiente de trabalho (VARGAS; ABBAD, 2006).

Segundo Peters (1967 apud VARGAS; ABBAD, 2006), são várias as maneiras com que as pessoas podem educar-se, tais como: lendo livros, explorando seu meio ambiente, viajando, conversando e, até mesmo, assistindo aulas.

Idéia similar a de Peters é apresentada por Pontual (1978 apud BASTOS, 1991, p. 88), baseado nas definições estabelecidas na década de 50 pelo Congresso Internacional de Ciências Administrativas: "a educação refere-se a todos os processos pelos quais as pessoas adquirem compreensão do mundo, bem como capacidade para lidar com seus problemas".

Nadler (1984 apud VARGAS; ABBAD, 2006) define educação como aprendizagem que visa preparar o indivíduo para um trabalho diferente, porém identificado, em um futuro próximo.

Segundo Vargas e Abbad (2006) essa definição de Nadler é importante porque trata, mais especificamente, do conceito de educação aplicado ao contexto das organizações de trabalho.

\subsubsection{Elementos do sistema de TD\&E}

TD\&E pode ser visto como um sistema composto por três subsistemas: (a) avaliação de necessidades; (b) planejamento do treinamento e sua execução e (c) avaliação do treinamento (BORGES-ANDRADE, 2002).

A avaliação de necessidades corresponde ao levantamento sistemático de conhecimentos, habilidades e atitudes nos níveis organizacional, das tarefas e individual. O segundo componente, planejamento e execução do treinamento, possui como característica básica a aplicação de técnicas estratégicas com o objetivo de proporcionar a aquisição sistemática de conhecimentos, habilidades e atitudes. Por fim, a avaliação do treinamento tem como função o levantamento controlado e sistemático de informações sobre o sistema como um todo (BORGESANDRADE, 1982 apud PILATI, 2006). 
Esses elementos mantêm um constante fluxo de informações e produtos entre si, sendo que o principal responsável pelo provimento de informações que garantem a retroavaliação das ações de TD\&E é a avaliação de treinamento, pois, a partir de seus resultados é possível o aperfeiçoamento constante do sistema (BORGESANDRADE, 2002).

Segundo Pilati (2006), essa definição proposta por Borges-Andrade (2002) insere o processo de treinamento dentro do contexto organizacional. Dessa forma, os outros componentes da organização influenciam e são influenciados pelas ações instrucionais.

O foco do presente estudo será o subsistema avaliação de treinamento. BorgesAndrade (2006b) ressalta que a avaliação de treinamento precisa ir além de medir e julgar o valor de eventos e programas de TD\&E. A avaliação precisa ser um meio de construirmos conhecimento a respeito de teorias instrucionais, ou de outra natureza, propostas e em uso. O autor ainda afirma que o momento da avaliação é uma ocasião para a realização de pesquisas aplicadas, pois é necessário produzir conhecimentos e gerar tecnologias de TD\&E que possibilitem o aumento da nossa competência técnica nacional, e é através da realização e divulgação de pesquisas que isso é possível.

\subsection{Impacto do Treinamento no Trabalho}

As ações de TD\&E nas organizações caracterizam-se pela intencionalidade de produzir um conjunto de efeitos, ou seja, promover o desenvolvimento de competências, isto é, formas de agir, de acordo com certos critérios e situações. Assim, mensurar impacto de TD\&E significa avaliar se o evento empreendido gerou melhorias nos desempenhos individuais, dos grupos e das organizações. Para mensurar qualquer aspecto, é importante que se conheça primeiramente o significado do fenômeno a ser avaliado (FREITAS et al., 2006).

O que seria, então, impacto de TD\&E?

O conceito de impacto de TD\&E, segundo Abbad (1999), pode ser compreendido à luz dos conceitos de transferência de treinamento e de desempenho no trabalho. 
Essa afirmação é compartilhada por Freitas et al. (2006), que afirmam que o impacto de TD\&E é medido em termos de transferência de TD\&E e da influência que os eventos instrucionais exercem sobre o desempenho pós-treinamento do participante.

Nesse sentido, transferência de treinamento seria a aplicação correta no trabalho de conhecimentos, habilidades e atitudes (CHAs) adquiridos nesses eventos instrucionais (FREITAS et al., 2006).

Latham (1989 apud FREITAS et al., 2006, p. 490), por sua vez, destaca ainda que "a transferência de TD\&E pode ser definida como o grau em que os participantes aplicam, em seus trabalhos, os CHAs adquiridos em TD\&E" (grifo nosso).

Em relação a desempenho, de acordo com Abbad (1999), o termo é usado para expressar conjuntos de comportamentos relacionados a tarefas, papéis, normas, expectativas, metas e padrões de eficiência e eficácia determinados em ambientes organizacionais.

Seguindo essa mesma linha de raciocínio, Freitas et al. (2006, p. 491) afirmam que:

O desempenho no trabalho pode ser visto como o conjunto de ações humanas voltadas para a realização de metas, passíveis de julgamento em termos de adequação, eficiência, eficácia e, portanto, muito sensíveis a normas e padrões culturais.

Dessa forma, verifica-se que o vínculo entre desempenho e impacto de TD\&E se consolida na medida em que as ações de TD\&E são sistematicamente planejadas visando promover o aperfeiçoamento dos desempenhos dos indivíduos no presente ou no futuro (FREITAS et al., 2006).

Diante disso, o impacto de TD\&E somente pode ser observado quando a pessoa treinada aplica os $\mathrm{CHAs}$ adquiridos e quando essa aplicação proporciona melhorias significativas na sua vida pessoal ou profissional, isso quer dizer que o impacto é o resultado positivo da transferência de aprendizagem e que pode haver transferência sem impacto significativo (FREITAS et al., 2006).

O conceito de impacto de TD\&E no desempenho do indivíduo conforme Freitas et al. (2006, p 491) seria, portanto, "a ocorrência de melhorias significativas no desempenho específico ou no desempenho geral da pessoa treinada, como resultados da aplicação, no trabalho, dos CHAs aprendidos em TD\&E". 
Para Abbad (1999, p. 104), impacto do treinamento no trabalho pode ser definido como "a auto-avaliação feita pelo próprio participante acerca dos efeitos produzidos pelo treinamento em seus níveis de desempenho, motivação, autoconfiança e abertura a mudanças nos processos de trabalho".

Para este trabalho adotou-se a definição de impacto do treinamento no trabalho de Abbad (1999), por se adequar melhor ao propósito dessa pesquisa.

\subsubsection{Importância da mensuração de impacto de TD\&E}

As organizações investem em ações instrucionais visando desenvolver habilidades motoras ou intelectuais, prover informações e produzir estratégias cognitivas e atitudes que poderão tornar os indivíduos mais competentes para desempenhar vários papéis, tanto no presente quanto no futuro (BORGES-ANDRADE, 2006a).

Dessa forma, a mensuração do impacto de TD\&E significa avaliar até que ponto os esforços despendidos nessas ações empreendidas efetivamente geraram os efeitos almejados, ou seja, proporcionaram melhorias nos desempenhos dos indivíduos, dos grupos e das organizações (FREITAS et al., 2006).

Essa avaliação pode ser uma oportunidade importante para tornar o processo de administração mais participativo e isso acontece quando os participantes opinam. Ela também pode tornar o processo de TD\&E mais transparente e isso ocorre quando os resultados de avaliação são divulgados aos participantes (BORGESANDRADE, 2006b).

O maior erro é cometido quando não há qualquer avaliação de TD\&E. Nesse caso, fica clara a falta de responsabilidade social e de compromisso com os treinandos, com o trabalho e com a organização que patrocinou o evento (BORGES-ANDRADE, 2006b).

De acordo com Borges-Andrade (2002) houve um crescimento da demanda por avaliação nas organizações que tradicionalmente fizeram altos investimentos em treinamento bem como naquelas que mais recentemente perceberam os valores estratégicos do conhecimento e do esforço na contínua qualificação de seu pessoal. 
Essa necessidade de se mensurar resultados de programas instrucionais provocou 0 surgimento de vários modelos de avaliação (PANTOJA; LIMA; BORGES-ANDRADE, 2001), tema abordado na próxima seção.

\subsubsection{Modelos de avaliação de TD\&E}

O modelo clássico de Kirpatrick (1976), posteriormente modificado por Hamblin (1978), tem como principal preocupação avaliar os resultados de um evento instrucional (CARVALHO; ABBAD, 2006). Segundo esse modelo, uma avaliação de treinamento deveria seguir cinco níveis: (I) reação, que levanta a opinião e a satisfação dos participantes sobre os diversos aspectos do treinamento; (II) aprendizagem, que verifica se os treinandos adquiriram as competências (CHAs) propostas nos objetivos instrucionais; (III) comportamento no cargo, que investiga se essas competências são utilizadas pelos participantes; (IV) organização, que se refere às mudanças que podem ter ocorrido na organização em decorrência do treinamento; e (V) valor final, que tem como foco a produção e ou o serviço prestado pela organização, o que geralmente envolve a comparação de custos do treinamento com os seus benefícios (HAMBLIM, 1978).

O presente estudo tem como objeto o nível comportamento no cargo.

Borges-Andrade (2006a) afirma que não é suficiente para o profissional de TD\&E identificar as razões para o sucesso ou o fracasso de um evento quando são coletados somente dados relativos a resultados.

É importante que outras características ou variáveis, que não somente as relativas puramente aos resultados sejam levadas em conta na avaliação dos eventos de treinamento (BORGES-ANDRADE, 1982 apud BORGES-ANDRADE, 2006a).

Nesse sentido, Borges-Andrade (1982 apud CARVALHO; ABBAD, 2006) propôs um modelo que inclui variáveis do ambiente como fatores importantes que influenciam todo o processo do treinamento, desde o levantamento de necessidades até os resultados a longo prazo.

O Modelo de Avaliação Integrado e Somativo (MAIS) elaborado por Borges-Andrade (1982 apud BORGES-ANDRADE, 2006a) é composto por cinco componentes: 
insumos, procedimentos, processos, resultados e ambiente. O último componente, ambiente, subdivide-se em quatro subcomponentes: avaliação de necessidades, disseminação, apoio e resultados a longo prazo. Carvalho e Abbad (2006, p. 3) destacaram a importância desse modelo afirmando que ele "[...] tem servido de base para muitas intervenções atuais, aplicadas e de pesquisa, em diversos contextos organizacionais". A figura 1 apresenta o modelo MAIS.

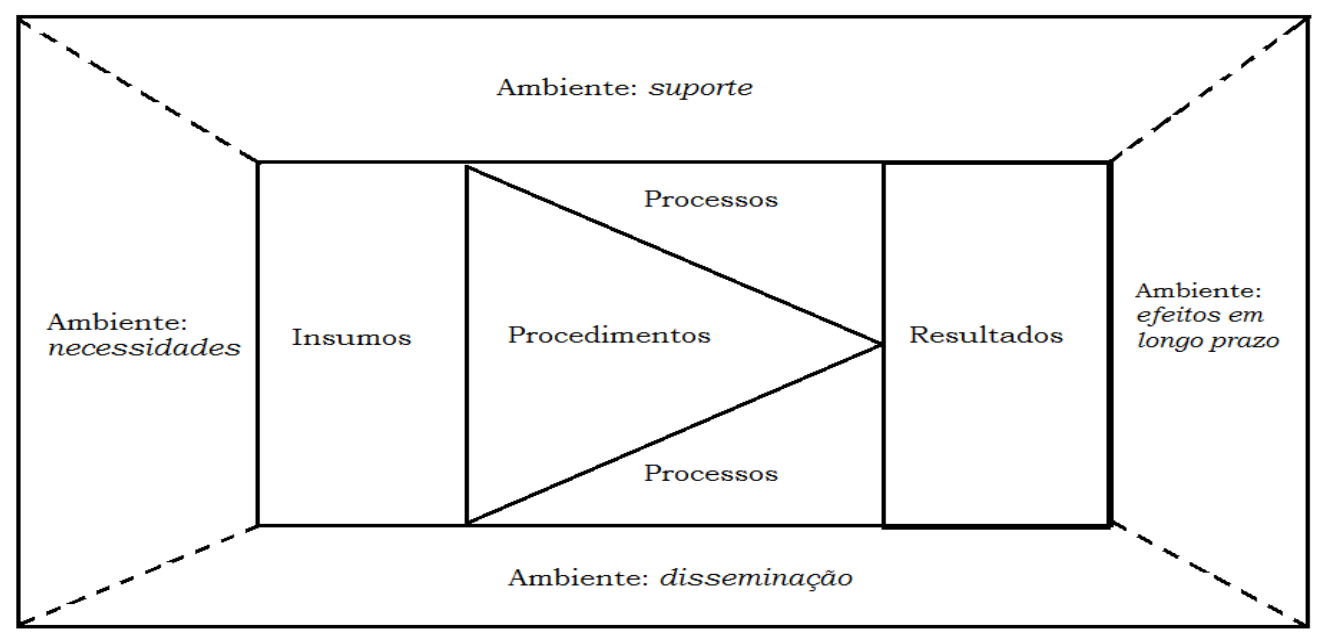

Figura 1: Modelo de Avaliação Integrado e Somativo - MAIS Fonte: Borges-Andrade (2006a, p. 344).

Abbad (1999), após receber influência desses e de outros modelos de avaliação, organizou os achados da literatura em avaliação de treinamento e sugeriu um modelo de predição do impacto do treinamento no trabalho, Modelo Integrado de Avaliação do Impacto do Treinamento no Trabalho - IMPACT. Esse modelo é composto por sete componentes: suporte organizacional, características do treinamento, características da clientela, reações, aprendizagem, suporte à transferência e impacto do treinamento no trabalho, sendo os seis primeiros componentes considerados preditores do impacto do treinamento no trabalho. A figura 2 mostra graficamente o modelo IMPACT. 


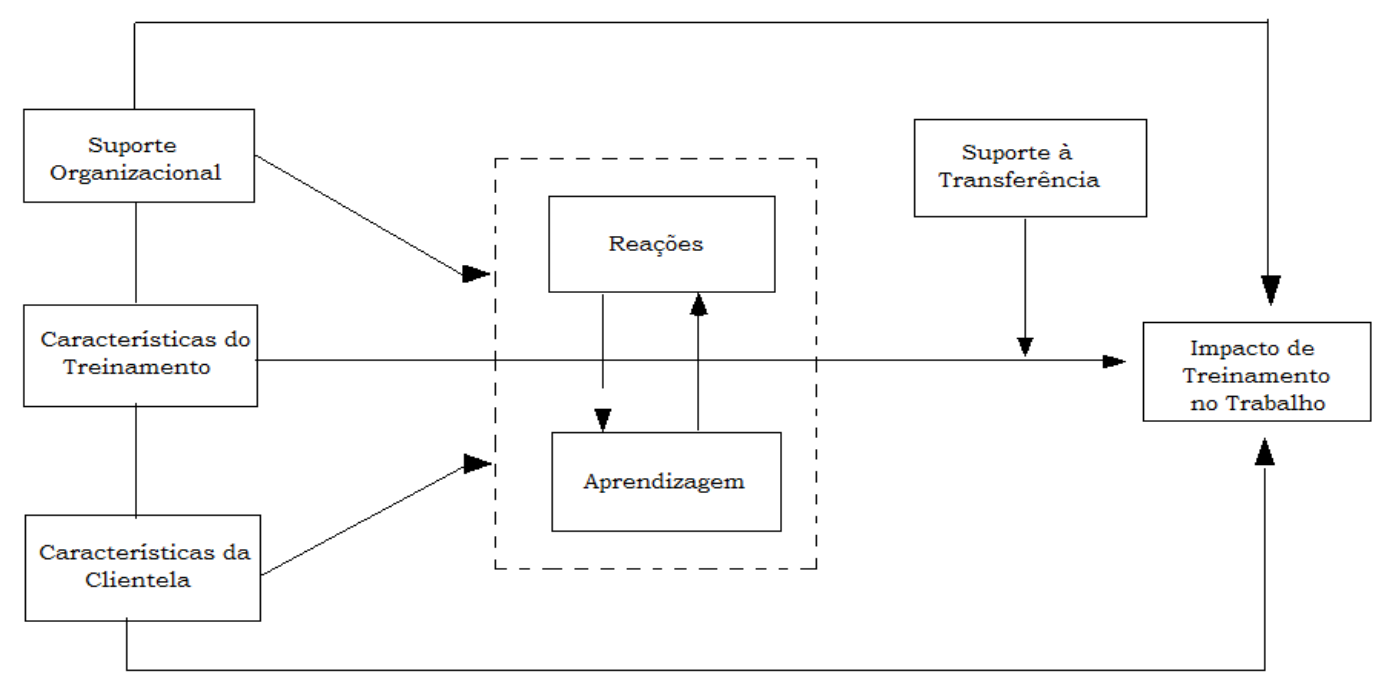

Figura 2: Representação esquemática dos componentes do Modelo de Avaliação do Impacto do Treinamento no Trabalho - IMPACT

Fonte: Abbad (1999, p. 99).

O instrumento de pesquisa utilizado neste trabalho será o IMPACT, esse instrumento mede o impacto do treinamento no trabalho em amplitude.

No que diz respeito a formas de se medir o impacto de treinamento no trabalho, segundo Sallorenzo (2000), são basicamente três: auto-avaliação em amplitude, auto-avaliação em profundidade e hetero-avaliação em amplitude. A auto-avaliação em amplitude, também chamada de impacto de treinamento no desempenho, avalia se $o$ treinamento teve impacto, também, em tarefas não relacionadas diretamente ao conteúdo aprendido no curso. A auto-avaliação em profundidade, denominada também de frequência de utilização em profundidade, avalia o impacto em tarefas estritamente relacionadas ao conteúdo do curso. Já na hetero-avaliação em amplitude, o impacto do treinamento no trabalho dos treinados é avaliado por supervisores ou colegas destes.

\subsubsection{Pesquisas de impacto de TD\&E}

Em revisão de literatura sobre avaliação de treinamento realizada por Abbad, Pilati e Pantoja (2003), foram analisadas publicações nacionais e estrangeiras no período de 1998 a 2001. 
Os principais resultados desse estudo foram apresentados de acordo com três categorias de variáveis antecedentes constantes de grande parte dos modelos teóricos de avaliação, são elas: a) características individuais; b) características do treinamento e c) suporte e clima (ABBAD; PILATI; PANTOJA, 2003). O Quadro 2, sumariza os principais resultados nacionais e estrangeiros na área de avaliação de treinamento.

\begin{tabular}{|l|l|l|}
\hline $\begin{array}{l}\text { Variáveis } \\
\text { Preditoras }\end{array}$ & \multicolumn{1}{|c|}{ Pesquisas Nacionais } & \multicolumn{1}{|c|}{ Pesquisas Estrangeiras } \\
\hline $\begin{array}{l}\text { Características } \\
\text { individuais }\end{array}$ & $\begin{array}{l}\text { Gênero, idade, tempo transcorrido } \\
\text { desde o término do nível superior, } \\
\text { escolaridade, cargo, motivação } \\
\text { para aprender, comprometimento, } \\
\text { intenção em aplicar o aprendido e } \\
\text { auto-eficácia. }\end{array}$ & $\begin{array}{l}\text { Motivação para aprender, } \\
\text { conscienciosidade, ansiedade, nível de } \\
\text { agressividade, emoções, tipo de } \\
\text { orientação para objetivos, estratégia de } \\
\text { aprendizagem (cognitivas e afetivas), } \\
\text { estratégias de aplicação das } \\
\text { habilidades, capacidade de imaginação } \\
\text { (imagery), auto-eficácia, locus de } \\
\text { controle e idade. }\end{array}$ \\
\hline $\begin{array}{l}\text { Características do } \\
\text { treinamento }\end{array}$ & $\begin{array}{l}\text { Similaridade entre situação de } \\
\text { treinamento e realidade de } \\
\text { trabalho, características do plano } \\
\text { instrucional (clareza e precisão } \\
\text { dos objetivos), natureza do } \\
\text { objetivo principal e uso de } \\
\text { exercícios práticos. }\end{array}$ & $\begin{array}{l}\text { Estabelecimento de objetivos } \\
\text { (específicos e difíceis) em treinamento, } \\
\text { estabelecimento de objetivos } \\
\text { combinado com feedback, } \\
\text { procedimentos multimídia, abordagem } \\
\text { humanista, estímulo ao } \\
\text { desenvolvimento de conhecimento } \\
\text { estratégico, estratégia instrucional } \\
\text { múltipla (aquisição de conhecimentos e } \\
\text { aplicação da habilidade), modelação } \\
\text { comportamental. }\end{array}$ \\
\hline Suporte e clima & $\begin{array}{l}\text { Suporte à transferência } \\
\text { (gerencial/social e material), } \\
\text { suporte organizacional (gestão do } \\
\text { desempenho e valorização do } \\
\text { servidor), expectativas de suporte } \\
\text { após o evento instrucional } \\
\text { (contexto pré-treinamento), reação } \\
\text { e contexto funcional. }\end{array}$ & $\begin{array}{l}\text { Clima para transferência como preditor } \\
\text { robusto do impacto do treinamento no } \\
\text { trabalho. }\end{array}$ \\
\hline
\end{tabular}

Quadro 2: Principais Resultados das Pesquisas Nacionais e Estrangeiras Fonte: Abbad; Pilati; Pantoja (2002, p. 213).

Nas pesquisas nacionais, em relação à categoria Características Individuais, foram observadas importantes relações positivas entre nível instrucional, motivação para aprender, comprometimento organizacional, intenção de aplicar o aprendido e auto-eficácia e o impacto do treinamento no trabalho. Já a relação entre o impacto e as variáveis idade, aprendizagem, tempo desde o término do último nível de escolarização e comprometimento com a carreira, foram identificadas como negativas. De maneira geral, nessa categoria, a contribuição das 
variáveis na explicação do impacto é pequena quando comparada àquela exercida por variáveis relacionadas a Suporte e Clima (ABBAD; PILATI; PANTOJA, 2003).

$\mathrm{Na}$ literatura nacional observou-se que é pequena a quantidade de estudos que buscam relacionar variáveis individuais e impacto do treinamento no trabalho, por outro lado, na literatura estrangeira verificou-se que esse conjunto de variáveis mantém uma relação importante com os resultados de treinamento (ABBAD; PILATI; PANTOJA, 2003).

Nos resultados das pesquisas nacionais relativos à categoria Características do Treinamento destacaram-se na explicação do impacto as seguintes variáveis: similaridade da situação de treinamento à realidade de trabalho, características do plano instrucional - por exemplo, clareza e precisão dos objetivos de ensino, natureza do objetivo principal, uso de exercícios práticos (ABBAD; PILATI; PANTOJA, 2003).

Os pesquisadores brasileiros têm dado pouca ênfase ao estudo de Características do Treinamento, pois são poucos os estudos que relacionam variáveis desse tipo com o impacto do treinamento no trabalho (ABBAD; PILATI; PANTOJA, 2003).

Nos estudos estrangeiros, apesar do ritmo acelerado com que proliferam treinamentos baseados em tecnologias sofisticadas e aumentaram as experiências de treinamento a distância, ainda há pouca pesquisa sobre esse tópico (ABBAD; PILATI; PANTOJA, 2003).

As pesquisas relativas à categoria Suporte e Clima mostraram como as mais fortes preditoras de impacto do treinamento no trabalho as seguintes variáveis: suporte à transferência (gerencial/social e material) suporte organizacional (subescalas e gestão do desempenho, valorização do servidor), expectativas de suporte após o evento instrucional (contexto pré-treinamento), reação, contexto funcional (ABBAD; PILATI; PANTOJA, 2003).

Em pesquisa realizada por Pantoja et al. (2005), foram investigadas as variáveis valores individuais e percepções de suporte organizacional à transferência de treinamento como preditores do impacto do treinamento no trabalho. Os resultados dessa pesquisa apontaram suporte psicossocial e 0 tipo motivacional conservadorismo/coletivismo como importantes preditores do impacto do 
treinamento no trabalho. A interação entre valores individuais e suporte organizacional à transferência foi marginalmente significativa.

\subsection{Suporte Organizacional: conceito e pesquisas}

Segundo Abbad et al. (2006), grande parte das causas de fracasso de programas de treinamento não está necessariamente relacionada a falhas nos sistemas instrucionais, mas ao ambiente externo a eles.

Nesse sentido, a avaliação de suporte em TD\&E torna-se um instrumento de fundamental importância para que haja maximização dos resultados de programas instrucionais, bem como de outros processos organizacionais relacionados a suporte (ABBAD et al., 2006).

Na linguagem cotidiana o termo suporte é usado para expressar apoio, sustentação, base, pilar, amparo e proteção. No que diz respeito à linguagem técnica, suporte é empregado de modo similar no sentido de condições organizacionais favoráveis de trabalho e, em alguns casos, compromisso da organização para com o indivíduo (ABBAD et al., 2006).

$\mathrm{Na}$ literatura, existem vários conceitos correlatos relativos ao ambiente que são utilizados para investigação de suporte no âmbito da avaliação de programas de TD\&E (ABBAD et al., 2006). O Quadro 3 apresenta uma síntese de alguns desses principais conceitos.

\begin{tabular}{|lll|}
\hline \multicolumn{1}{|l|}{ CONCEITOS RELACIONADOS A SUPORTE } & \\
\hline \multicolumn{1}{|c|}{ Conceito } & \multicolumn{1}{c|}{ Definição } & \multicolumn{1}{c|}{ Autor(es) } \\
\hline Suporte organizacional & $\begin{array}{l}\text { Percepção dos indivíduos a respeito do quanto a } \\
\text { organização se preocupa com o bem-estar e valoriza as } \\
\text { contribuições dos indivíduos que nela trabalham. }\end{array}$ & $\begin{array}{l}\text { Abbad (1999); Abbad, } \\
\text { Pilati e Borges- } \\
\text { Andrade (1999) }\end{array}$ \\
\hline $\begin{array}{l}\text { Suporte Gerencial ao } \\
\text { treinamento }\end{array}$ & $\begin{array}{l}\text { Indicadores de apoio gerencial à transferência de } \\
\text { treinamento, presentes no ambiente organização antes, } \\
\text { durante e após o treinamento. }\end{array}$ & Broad (1982) \\
\hline Clima para transferência & $\begin{array}{l}\text { Percepção do indivíduo sobre o apoio que recebe de } \\
\text { ambiente organizacional para transferir novas } \\
\text { aprendizagens para o trabalho. Este conceito inclui }\end{array}$ & $\begin{array}{l}\text { Rouiller e Goldstein } \\
\text { (1993) }\end{array}$ \\
\hline
\end{tabular}




\begin{tabular}{|c|c|c|}
\hline \multicolumn{3}{|c|}{ CONCEITOS RELACIONADOS A SUPORTE } \\
\hline Conceito & Definição & Autor(es) \\
\hline & $\begin{array}{l}\text { fatores situacionais antecedentes e conseqüências } \\
\text { associada à transferência de treinamento. }\end{array}$ & \\
\hline Suporte à transferência & $\begin{array}{l}\text { Percepção do indivíduo sobre o apoio que recebe de } \\
\text { colegas e chefias para aplicar, no trabalho, novas } \\
\text { habilidades. }\end{array}$ & $\begin{array}{l}\text { Abbad (1999); Abbad } \\
\text { e Sallorenzo (2001) }\end{array}$ \\
\hline $\begin{array}{l}\text { Cuiltura de } \\
\text { aprendizagem contínua }\end{array}$ & $\begin{array}{l}\text { Padrão compartilhado de significados e expectativas } \\
\text { acerca de quanto a organização maximiza os processos de } \\
\text { inovação e a competitividade, promovendo a aquisição } \\
\text { constante de habilidades, conhecimentos e } \\
\text { comportamentos oriundos dos mais distintos meios, a fim } \\
\text { de modificar o ambiente de trabalho em algum aspecto. }\end{array}$ & $\begin{array}{l}\text { Tracey, Tannenbaum } \\
\text { e Kavanagh (2001) }\end{array}$ \\
\hline Suporte à aprendizagem & $\begin{array}{l}\text { Percepção do indivíduo sobre o apoio de pares e chefias à } \\
\text { aprendizagem e à aplicação no trabalho de CHAs } \\
\text { adquiridos em situaçães formais (programas de TD\&E) e } \\
\text { informais de aprendizagem. }\end{array}$ & Coelho Jr. (2004) \\
\hline $\begin{array}{l}\text { Suporte à aprendizagem } \\
\text { contínua }\end{array}$ & $\begin{array}{l}\text { Percepção do indivíduo sobre a presença de condições } \\
\text { favoráveis à aprendizagem no grupo de trabalho. }\end{array}$ & $\begin{array}{l}\text { Freitas (2005); } \\
\text { Pantoja (2004) }\end{array}$ \\
\hline
\end{tabular}

Quadro 3: Conceitos Relacionados a Suporte

Fonte: Abbad et al. (2006, p. 397)

Nesta pesquisa a variável estudada será o suporte organizacional. A seguir são apresentados alguns de seus conceitos.

Segundo Abbad et al. (2006, p. 396):

Suporte organizacional [...] é um conceito definido por pesquisadores da área de comportamento organizacional, com base em abordagens teóricas oriundas da sociologia e da psicologia, com o objetivo de investigar 0 relacionamento entre percepções dos indivíduos sobre suporte, comprometimento, cidadania e desempenho.

A expressão suporte organizacional, de acordo com Abbad, Freitas e Pilati (2006, p. 243):

refere-se a crenças ou percepções globais, desenvolvidas pelos trabalhadores sobre o quanto a organização valoriza suas contribuições e cuida do seu bem-estar (avaliação ecológica). Trata-se, portanto, de crenças do trabalhador sobre o comprometimento da organização para com eles.

No estudo brasileiro realizado por Oliveira-Castro, Pilati e Borges-Andrade (1999), suporte organizacional é um construto multidimensional, formado pelas opiniões dos empregados ou funcionários relativas às práticas de gestão de desempenho, às 
exigências e à carga de trabalho, ao suporte material e às práticas de promoção, ascensão e salários da organização.

Percepções desfavoráveis de suporte organizacional, de acordo com Abbad, Freitas e Pilati (2006), podem provocar problemas de desempenho não devidos à falta de CHAs no trabalho, mas à falta de condições favoráveis ao desempenho competente e/ou de motivação em decorrência de restrições situacionais no ambiente de trabalho.

No que diz respeito às pesquisas, Lima, Borges-Andrade e Vieira (1989) foram os pioneiros no Brasil na investigação do relacionamento entre condições ambientais e impacto. Nesse estudo foi analisado o impacto de cursos de curta duração em instituições de pesquisa agrícola, em seus resultados, encontraram predominância das condições de trabalho e de vida na organização, na explicação do impacto dos cursos no desempenho.

Em sua maioria, às pesquisas nacionais realizadas em diferentes contextos na última como as de Sallorenzo (2000), Lacerda e Abbad (2003), Carvalho e Abbad (2006), associaram suporte à transferência de treinamento ao impacto do treinamento no trabalho.

Em relação à variável suporte organizacional, ainda são muito escassos os estudos relacionando as percepções de suporte organizacional e os resultados de treinamento. Entre os pesquisadores não existe consenso sobre quais deveriam ser as variáveis organizacionais de interesse e nem sobre o nível de análise em que deveriam ser estudadas (ABBAD; SALLORENZO, 2001). Estudo recente com essa variável realizado por Paschoal, Torres e Porto (2010), relacionou o impacto do suporte organizacional e do suporte social sobre o bem-estar no trabalho, os seus resultados indicaram que tanto o suporte organizacional como o suporte social têm impacto direto no bem-estar.

Oliveira-Castro, Pilati e Borges-Andrade (1999), tendo como um dos objetivos suprir a carência de medidas de suporte organizacional, desenvolveram e validaram um questionário brasileiro de suporte organizacional utilizado no presente trabalho e detalhado na seção sobre instrumentos de pesquisa. 


\section{MÉTODOS E TÉCNICAS DE PESQUISA}

Este capítulo descreve o tipo de pesquisa desenvolvido, as características da organização e os cursos em estudo, as características da amostra, os instrumentos de pesquisa utilizados e os procedimentos de coleta e análise dos dados.

\subsection{Tipo e descrição geral da pesquisa}

A classificação da pesquisa teve como base a taxionomia apresentada por Vergara (2009), que a qualifica em relação a dois aspectos: quanto aos fins e quanto aos meios.

Quanto aos fins, a pesquisa é considerada descritiva e explicativa, na medida em que descreveu o impacto no desempenho na auto-avaliação de dois cursos e a percepção de suporte organizacional dos respondentes e analisou possíveis relações entre essas duas variáveis.

Quanto aos meios, esta pesquisa é avaliada como de campo uma vez que realizou uma investigação empírica no local onde ocorreu o fenômeno (VERGARA, 2009).

Em relação à natureza ou tratamento dos dados, a pesquisa é classificada como quantitativa. O método quantitativo é apropriado "para medir opiniões, atitudes e preferência como comportamentos" (ZANELLA, 2006, p. 89).

\subsection{Caracterização da organização}

O Tribunal Regional Federal 1ㄹ Região - TRF 1ㄹ Região, de acordo com o art. 106 da Constituição Federal, juntamente com os juízes federais, é órgão da justiça federal, com sede na Capital Federal e jurisdição no Distrito Federal e nos Estados do Acre, Amapá, Amazonas, da Bahia, de Goiás, do Maranhão, de Mato Grosso, Minas Gerais, do Pará, Piauí, de Rondônia, Roraima e Tocantins, compõe-se de 
vinte e sete (27) juízes vitalícios, nomeados pelo presidente da República. O Tribunal funciona em Plenário, Corte Especial, seções especializadas e turmas especializadas. Atualmente, o órgão possui, aproximadamente, 1200 servidores. No Anexo 1 deste trabalho, encontra-se a estrutura organizacional do órgão.

Em novembro de 2007, o órgão criou a sua Universidade Corporativa - UniCorp com o objetivo de impulsionar a criação de uma cultura de aprendizagem contínua, em que o corpo funcional compartilhará informações e práticas de trabalho e resolverá questões intrínsecas a cada unidade com maior qualidade e rapidez. Inicialmente, foram disponibilizados alguns cursos no primeiro semestre de 2008 , após mudança de gestão ocorrida em abril desse mesmo ano, as suas atividades foram paralisadas. A nova gestão, que assumiu em abriu de 2010, possui vários projetos que visam à capacitação de seu corpo funcional.

\subsection{Amostra}

A amostra correspondeu a dois grupos que participaram de dois cursos no órgão. Para facilitar a análise dos dados, considerar-se-á como Grupo A os treinandos do curso técnicas de segurança para autoridades; e como Grupo B, os treinandos do curso sistemas GPD e G-DOC.

O curso técnicas de segurança para autoridades foi planejado em módulos e preparado após pesquisa de necessidades de treinamento junto ao público alvo, os agentes de segurança. O objetivo geral era capacitar os servidores que atuam diretamente com autoridades. Em julho de 2010, foram realizados os módulos I e II com duração de 12 horas, distribuídas em 3 manhãs de aulas, compreendendo aulas teóricas e práticas. Participaram desses módulos 30 servidores requisitados, ou seja, servidores que não pertencem ao quadro funcional da organização. Foram entregues 28 questionários, pois dois servidores encontravam-se de férias. Retornaram 20 questionários respondidos o que corresponde a uma taxa de resposta de aproximadamente $67 \%$. A classificação dos participantes desse grupo, segundo características sócio-demográficas, é apresentada no quadro abaixo: 


\begin{tabular}{|c|c|c|l|}
\hline Gênero & Faixa Etária & \multicolumn{1}{|c|}{ Escolaridade } & \multicolumn{1}{c|}{ Tempo de Serviço } \\
\hline Masculino: 20 & - De 31 a 40 anos: 5 & - $1^{\text {a }}$ grau completo: 4 & - Até 2 anos: 15 \\
& - De 41 a 50 anos: 9 & - $2^{-0}$ grau completo: 12 & - De 6 a 10 anos: 1 \\
& - De 51 a 60 anos: 6 & - Superior imcompleto: 2 & - Mais de 15 anos: 4 \\
& & - Superior completo: 1 & \\
& & - Especialização: 1 & \\
\hline
\end{tabular}

Quadro 4: Características da amostra - Grupo A

O curso nos sistemas GPD e G-DOC teve como objetivo capacitar os servidores que trabalham com os dois sistemas que são usados no gerenciamento do processo digital, implantado no Tribunal no início desse ano. O curso foi ministrado em agosto de 2010 no local de trabalho dos servidores. A duração foi de 4 horas distribuídas em dois períodos. Os instrutores eram servidores do órgão e foram capacitados para este trabalho, passando por um aprendizado de didática. Realizaram o curso 52 servidores lotados em 8 turmas do órgão. Foram entregues 45 questionários, tendo em vista que uma das turmas se recusou a participar da pesquisa. Retornaram 39 respondidos, destes, 2 foram descartados devido a questões não respondidas, portanto, a taxa de resposta correspondeu a aproximadamente $71 \%$. Os respondentes participantes do Grupo B da amostra apresentaram as seguintes características:

\begin{tabular}{|l|l|l|l|}
\hline \multicolumn{1}{|c|}{ Gênero } & \multicolumn{1}{|c|}{ Faixa Etária } & \multicolumn{1}{|c|}{ Escolaridade } & \multicolumn{1}{c|}{ Tempo de Serviço } \\
\hline Masculino: 10 & - Até 20 anos: 1 & - 2o grau completo: 4 & - Até 2 anos: 2 \\
Feminino: 27 & - De 20 a 30 anos: 5 & - Superior incompleto: 5 & - De 2 a 5 anos: 4 \\
& - De 31 a 40 anos: 9 & - Superior completo: 16 & - De 6 a 10 anos: 7 \\
& - De 41 a 50 anos: 19 & - Especialização: 11 & - De 11 a 15 anos: 10 \\
& - De 51 a 60 anos: 3 & - Mestrado: 1 & - Mais de 15 anos: 14 \\
\hline
\end{tabular}

Quadro 5: Características da amostra - Grupo B 


\subsection{Instrumentos de pesquisa}

O instrumento de pesquisa utilizado é composto por duas escalas, a escala de Impacto do Treinamento no Trabalho - IMPACT, proposta por Abbad (1999); e a escala de Percepção de Suporte Organizacional, desenvolvida por Oliveira-Castro, Pilati e Borges-Andrade (1999). Também foi utilizado um questionário para obtenção do perfil sócio-demográfico da população.

A escala IMPACT é uma escala unifatorial composta por 12 itens, associados a uma escala de concordância do tipo Likert de sete pontos. Esses 12 itens englobam sete componentes: percepção de Suporte Organizacional, Características do Treinamento, Características da Clientela, Reação, Aprendizagem, Suporte à Transferência e Impacto de Treinamento no Trabalho.

O componente Suporte Organizacional agrega variáveis referentes às práticas organizacionais de gestão de desempenho e valorização do servidor. Características do Treinamento referem-se a variáveis como: área de conhecimento do curso, duração, natureza do objetivo principal do curso, origem institucional do instrutor, escolaridade e desempenho do instrutor e qualidade do material didático. O componente Características da Clientela contém informações demográficas, funcionais, motivacionais e atitudinais relativas aos participantes dos treinamentos. O quarto componente, Reação, refere-se às opiniões dos treinandos quanto à programação, ao apoio ao desenvolvimento do curso, à aplicabilidade e utilidade do treinamento, aos resultados, às expectativas de suporte organizacional e ao desempenho do instrutor. O componente Aprendizagem diz respeito ao grau de assimilação e retenção dos conteúdos ensinados nos cursos, medido por meio de escores obtidos em provas de conhecimentos. O sexto componente, Suporte à Transferência, avalia a opinião do treinando sobre o suporte ambiental ao uso eficaz, no trabalho, das novas habilidades adquiridas no treinamento. E, finalmente, o último componente Impacto do Treinamento no Trabalho refere-se à autoavaliação do treinando acerca dos efeitos produzidos pelo treinamento em seus níveis de desempenho, motivação, autoconfiança e abertura a mudanças nos processos de trabalho (ABBAD, 1999). 
Em análise fatorial confirmatória realizada pela autora, as cargas fatoriais dos itens variaram de 0,43 até valores superiores a 0,90. O índice de consistência interna (alpha de Cronbach) foi superior a 0,90.

A escala de Percepção de Suporte Organizacional é composta por 52 itens agrupados em 4 fatores: Fator 1: Gestão de Desempenho; Fator 2: Carga de Trabalho; Fator 3: Suporte Material; e Fator 4: Práticas Organizacionais de Ascensão, Promoção e Salários. O fator geral, denominado percepção de suporte organizacional apresentou elevado índice de consistência interna $(\alpha=0,95)$ e explicação de $28 \%$ da variância das respostas da amostra aos itens. No Quadro 1 consta a definição de cada fator bem como o número de itens e seus respectivos índices de confiabilidade.

\begin{tabular}{|c|c|c|c|}
\hline FATORES & DEFINIÇÕES & $\begin{array}{l}\text { N. de } \\
\text { ITENS }\end{array}$ & $\begin{array}{c}\text { ÍNDICES DE } \\
\text { CONFIABILIDADE }\end{array}$ \\
\hline $\begin{array}{l}\text { Gestão de } \\
\text { desempenho }\end{array}$ & $\begin{array}{l}\text { Refere-se à opinião dos trabalhadores sobre as } \\
\text { práticas organizacionais de gerenciamento do } \\
\text { desempenho do funcionário: estabelecimento de } \\
\text { metas, valorização de novas idéias, conhecimento } \\
\text { de dificuldades na execução eficaz das tarefas } \\
\text { organizacionais de gerenciamento do desempenho } \\
\text { dos funcionários, como estabelecimento de metas, } \\
\text { valorização de novas idéias, conhecimento de } \\
\text { dificuldades associadas à execução eficaz das } \\
\text { tarefas e esforço organizacional de atualização de } \\
\text { seus colaboradores ou empregados em face das } \\
\text { novas tecnologias e processos de trabalho. }\end{array}$ & 13 & 0,87 \\
\hline $\begin{array}{l}\text { Carga de } \\
\text { trabalho }\end{array}$ & $\begin{array}{l}\text { Refere-se às exigências e à sobrecarga de tarefas } \\
\text { atribuídas aos funcionários, devido às altas } \\
\text { demandas de produção. }\end{array}$ & 9 & 0,80 \\
\hline Suporte material & $\begin{array}{l}\text { Refere-se à opinião da amostra sobre a } \\
\text { disponibilidade, adequação, suficiência e qualidade } \\
\text { dos recursos materiais e financeiros fornecidos pela } \\
\text { organização para apoiar a execução eficaz das } \\
\text { tarefas. }\end{array}$ & 17 & 0,91 \\
\hline $\begin{array}{l}\text { Práticas } \\
\text { organizacionais }\end{array}$ & $\begin{array}{l}\text { Refere-se à opinião da amostra acerca das práticas } \\
\text { organizacionais de retribuição financeira, promoções }\end{array}$ & 11 & 0,83 \\
\hline
\end{tabular}




\begin{tabular}{|l|l|l|l|}
\hline \multicolumn{1}{|c|}{ FATORES } & DEFINIÇÕES & $\begin{array}{c}\text { N. de } \\
\text { ITENS }\end{array}$ & $\begin{array}{c}\text { ÍNDICES DE } \\
\text { CONFIABILIDADE }\end{array}$ \\
\hline $\begin{array}{l}\text { de ascensão, } \\
\text { promoção e } \\
\text { salários }\end{array}$ & e ascensão funcionais. & & \\
\hline
\end{tabular}

Quadro 6: Fatores, definições, quantidade de itens e índices de confiabilidade dos fatores da Escala de Percepção de Suporte Organizacional

Fonte: Oliveira-Castro; Pilati; Borges-Andrade (1999).

A primeira parte do questionário foi composta pelas instruções de preenchimento da pesquisa e explicação do seu objetivo. A segunda parte incluiu, respectivamente, as escalas de impacto do treinamento no trabalho e de percepção de suporte organizacional. Finalmente, a terceira parte correspondeu aos dados sóciodemográficos, como: gênero, faixa etária, tempo na organização e escolaridade.

\subsection{Procedimentos de coleta e de análise de dados}

Inicialmente, foi solicitada autorização à Secretaria de Recursos Humanos do órgão para a realização da pesquisa e solicitada relação dos servidores que participaram dos cursos em estudo com as suas respectivas lotações. Após envio de e-mail, pela secretaria, às respectivas lotações dos servidores informando a ida da pesquisadora, esta se dirigiu aos locais informados para entrega dos questionários, sendo a coleta dos dados realizada no período de 6 a 21 de outubro de 2010.

A organização recomendou que os questionários fossem entregues aos chefes dos setores no qual os participantes estavam subordinados. Para dar maior confiabilidade quanto ao caráter confidencial das respostas, cada questionário foi acondicionado em envelopes pardos. No ato da entrega foi explicado o objetivo do estudo e sua relevância, a importância de sua colaboração bem como a garantia do anonimato e sigilo das respostas. Foi informado, também, que a pesquisadora retornaria para recolher os questionários respondidos em dois dias.

Em relação à análise estatística dos dados, foram utilizados os softwares Microsoft Excel (Office 2007) e o Statistical Package for the Social Sciences (SPSS) 18.0. Através desses aplicativos, foram calculadas medidas descritivas, tais como a média 
para identificação da tendência central e o desvio padrão, para identificar a dispersão dos respondentes com relação ao ponto central; também foram explorados padrões de relação entre as variáveis do estudo através de correlações de Pearson. A fim de refinar os resultados, realizou-se o cálculo da freqüência das respostas de cada um dos itens dos questionários. 


\section{RESULTADOS E DISCUSSÃO}

Este capítulo destina-se à apresentação e discussão dos resultados desta pesquisa e está estruturado segundo seus objetivos: i. resultados descritivos do impacto do treinamento no trabalho; ii. avaliação da percepção de suporte organizacional; e iii. relações entre as variáveis em estudo.

\subsection{Resultados descritivos do impacto do treinamento no trabalho}

Nesta seção são exibidos os resultados descritivos do impacto em amplitude dos participantes após a realização dos eventos de treinamento, que corresponde a um dos objetivos específicos da presente pesquisa.

O modelo de avaliação proposto por Hamblim (1978), mencionado no referencial teórico, compõe-se de cinco níveis: reação, aprendizagem, comportamento no cargo, organização e valor final. Nesse estudo, realizou-se a avaliação em nível de comportamento no cargo.

No que se refere à forma de se mensurar o impacto do treinamento no trabalho, foi realizada a auto-avaliação em amplitude ou impacto de treinamento no desempenho, essa forma avalia se o evento instrucional teve impacto, também, em tarefas não relacionadas diretamente ao conteúdo aprendido no curso.

O impacto em amplitude foi colhido por meio do instrumento IMPACT que contem 12 itens, respondido por intermédia de uma escala do tipo Likert de 7 pontos de concordância, onde 7 corresponde a "concordo totalmente" com a afirmativa e 1, "discordo totalmente" da afirmativa. As respostas numéricas foram submetidas a análises estatísticas e são apresentadas nas Tabelas 1 e 2. A Tabela 1 corresponde às respostas do Grupo $A$ da amostra, composto por 20 treinandos do curso técnicas de segurança para autoridades e a Tabela 2, às respostas do Grupo B, composto por 37 treinandos do curso sistemas GPD e G-DOC.

Nas Tabelas são apresentadas as médias e os desvios padrão, os percentuais de discordância, de concordância e as opiniões neutras das amostras. Com o intuito de 
facilitar a descrição dos resultados, as freqüências de respostas de discordância (1, 2 e 3) e as de concordância (5, 6 e 7) foram somadas entre si.

Tabela 1: Impacto em amplitude - Grupo A

\begin{tabular}{|c|c|c|c|c|c|}
\hline Item do Questionário & Média & DP & $\% \mathbf{D}$ & $\% \mathbf{N} / \mathbf{N}$ & $\% \mathbf{C}$ \\
\hline $\begin{array}{l}\text { 1. Utilizo, com freqüência, em meu trabalho atual, o que foi ensinado } \\
\text { no treinamento. }\end{array}$ & 5,75 & 1,07 & 5 & 5 & 90 \\
\hline $\begin{array}{l}\text { 2. Aproveito as oportunidades que tenho para colocar em prática o } \\
\text { que me foi ensinado no treinamento. }\end{array}$ & 6,10 & 0,85 & & 5 & 95 \\
\hline $\begin{array}{l}\text { 3. As habilidades que aprendi no treinamento fizeram com que eu } \\
\text { cometesse menos erros, em meu trabalho, em atividades relacionadas } \\
\text { ao conteúdo do treinamento. }\end{array}$ & 5,80 & 1,36 & 5 & & 95 \\
\hline 4. Recordo-me bem dos conteúdos ensinados no treinamento. & 6,25 & 0,72 & & & 100 \\
\hline $\begin{array}{l}\text { 5. Quando aplico o que aprendi no treinamento, executo meu trabalho } \\
\text { com maior rapidez. }\end{array}$ & 5,90 & 1,48 & 10 & & 90 \\
\hline $\begin{array}{l}\text { 6. A qualidade do meu trabalho melhorou nas atividades diretamente } \\
\text { relacionadas ao conteúdo do treinamento. }\end{array}$ & 5,90 & 0,85 & & 10 & 90 \\
\hline $\begin{array}{l}\text { 7. A qualidade do meu trabalho melhorou mesmo naquelas atividades } \\
\text { que não pareciam estar relacionadas ao conteúdo do treinamento. }\end{array}$ & 5,80 & 0,83 & & 10 & 90 \\
\hline $\begin{array}{l}\text { 8. Minha participação no treinamento serviu para aumentar minha } \\
\text { motivação para o trabalho. }\end{array}$ & 6,10 & 0,85 & & 5 & 95 \\
\hline $\begin{array}{l}\text { 9. Minha participação nesse treinamento aumentou minha } \\
\text { autoconfiança. (Agora tenho mais confiança na minha capacidade de } \\
\text { executar meu trabalho com sucesso). }\end{array}$ & 6,55 & 0,51 & & & 100 \\
\hline $\begin{array}{l}\text { 10. Após minha participação no treinamento, tenho sugerido, com } \\
\text { mais freqüência, mudanças nas rotinas de trabalho. }\end{array}$ & 5,65 & 0,99 & & 15 & 85 \\
\hline $\begin{array}{l}\text { 11. Esse treinamento que fiz tornou-me mais receptivo a mudanças no } \\
\text { trabalho. }\end{array}$ & 6,05 & 0,83 & & 5 & 95 \\
\hline $\begin{array}{l}\text { 12. O treinamento que fiz beneficiou meus colegas de trabalho, que } \\
\text { aprenderam comigo algumas novas habilidades. }\end{array}$ & 6,00 & 0,86 & & 5 & 95 \\
\hline Total & 5,99 & 0,25 & 2 & 5 & 93 \\
\hline
\end{tabular}

Legenda: $\mathrm{DP}=$ desvio padrão. $\mathrm{C}=$ concordo. $\mathrm{N} / \mathrm{N}=$ não concordo, nem discordo. $\mathrm{D}=$ discordo.

Fonte: Dados da pesquisa.

Conforme pode ser observado na Tabela 1, as médias de todos os itens apresentaram bons resultados, variando de 6,55 a 5,65. Apenas em dois itens o desvio padrão situou-se acima de 1 (1,07 e 1,48), o que demonstra baixa dispersão na avaliação do impacto, confirmando a boa avaliação dos participantes a respeito do impacto do curso ministrado, onde $93 \%$ das respostas concentraram-se nos escores de concordância.

Dos doze itens da escala, onze obtiveram concentração de 90\% das respostas, ou mais, nos escores de concordância. Destaque para dois itens que concentraram $100 \%$ das respostas nos escores de concordância, o item 9, onde o participante expressa que após participar do treinamento, a sua autoconfiança aumentou, tendo mais confiança na sua capacidade de executar o trabalho com sucesso, com média 6,55 e desvio padrão 0,51; e o item 4, onde o participante afirma que se 
recorda bem dos conteúdos ensinados no treinamento, com média igual a 6,25 e desvio padrão de 0,72 .

O item 10, que corresponde à afirmação de que após sua participação no treinamento, tem sugerido, com mais freqüência, mudanças nas rotinas de trabalho obteve a menor média, 5,65 e desvio padrão de 0,99.

É importante destacar os resultados do item 7. A qualidade do meu trabalho melhorou mesmo naquelas atividades que não pareciam estar relacionadas ao conteúdo do treinamento, com média igual a 5,80 e desvio padrão de 0,83 , onde 90\% dos participantes concordaram com a afirmativa. Isso significa que, para a grande maioria dos treinandos, o treinamento gerou melhorias em outras atividades, não se restringindo, apenas, aquelas relacionadas estritamente ao conteúdo do curso.

Tabela 2: Impacto em amplitude - Grupo B

\begin{tabular}{|c|c|c|c|c|c|}
\hline Item do Questionário & Média & DP & $\% \mathbf{D}$ & $\% \mathbf{N} / \mathbf{N}$ & $\% \mathrm{C}$ \\
\hline $\begin{array}{l}\text { 1. Utilizo, com freqüência, em meu trabalho atual, o que foi ensinado } \\
\text { no treinamento. }\end{array}$ & 4,73 & 1,95 & 15,3 & 5,4 & 43,2 \\
\hline $\begin{array}{l}\text { 2. Aproveito as oportunidades que tenho para colocar em prática o que } \\
\text { me foi ensinado no treinamento. }\end{array}$ & 5,19 & 2,03 & 27 & & 67,5 \\
\hline $\begin{array}{l}\text { 3. As habilidades que aprendi no treinamento fizeram com que eu } \\
\text { cometesse menos erros, em meu trabalho, em atividades relacionadas } \\
\text { ao conteúdo do treinamento. }\end{array}$ & 5 & 1,81 & 21,6 & 10,8 & 51,3 \\
\hline 4. Recordo-me bem dos conteúdos ensinados no treinamento. & 4,97 & 1,40 & 18,9 & 16,2 & 37,8 \\
\hline $\begin{array}{l}\text { 5. Quando aplico o que aprendi no treinamento, executo meu trabalho } \\
\text { com maior rapidez. }\end{array}$ & 5,16 & 1,82 & 21,6 & 10,8 & 62,1 \\
\hline $\begin{array}{l}\text { 6. A qualidade do meu trabalho melhorou nas atividades diretamente } \\
\text { relacionadas ao conteúdo do treinamento. }\end{array}$ & 5,11 & 1,71 & 18,9 & 13,5 & 54 \\
\hline $\begin{array}{l}\text { 7. A qualidade do meu trabalho melhorou mesmo naquelas atividades } \\
\text { que não pareciam estar relacionadas ao conteúdo do treinamento. }\end{array}$ & 3,84 & 1,94 & 40,5 & 16,2 & 24,3 \\
\hline $\begin{array}{l}\text { 8. Minha participação no treinamento serviu para aumentar minha } \\
\text { motivação para o trabalho. }\end{array}$ & 4,49 & 2,04 & 29,7 & 16,2 & 40,5 \\
\hline $\begin{array}{l}\text { 9. Minha participação nesse treinamento aumentou minha } \\
\text { autoconfiança. (Agora tenho mais confiança na minha capacidade de } \\
\text { executar meu trabalho com sucesso). }\end{array}$ & 4,59 & 1,92 & 27 & 21,6 & 43,2 \\
\hline $\begin{array}{l}\text { 10. Após minha participação no treinamento, tenho sugerido, com mais } \\
\text { freqüência, mudanças nas rotinas de trabalho. }\end{array}$ & 3,62 & 1,69 & 45,9 & 24,3 & 18,9 \\
\hline $\begin{array}{l}\text { 11. Esse treinamento que fiz tornou-me mais receptivo a mudanças no } \\
\text { trabalho. }\end{array}$ & 4,54 & 1,73 & 21,6 & 29,7 & 35,1 \\
\hline $\begin{array}{l}\text { 12. O treinamento que fiz beneficiou meus colegas de trabalho, que } \\
\text { aprenderam comigo algumas novas habilidades. }\end{array}$ & 4,59 & 1,76 & 24,3 & 21,6 & 37,8 \\
\hline Total & 4,65 & 0,50 & 27 & 15 & 58 \\
\hline
\end{tabular}

A observação das médias do Grupo B mostrou que apenas dois itens obtiveram médias inferiores a 4 (itens 7 e 10). O escore médio dos itens situou-se em 4,65, 
abaixo do observado no Grupo A, indicando que os participantes deste curso perceberam um impacto menor do que o observado naquele.

Os itens que apresentaram melhores resultados em relação ao conjunto de questões foram: 2. Aproveito as oportunidades que tenho para colocar em prática o que me foi ensinado no treinamento, com uma média de 5,19 e desvio padrão igual a 2,03; e o item 5. Quando aplico o que aprendi no treinamento, executo meu trabalho com maior rapidez, com média igual a 5,16 e desvio padrão de 1,82.

Assim como na avaliação do Grupo A, o item de pior média foi o 10. Após minha participação no treinamento, tenho sugerido, com mais freqüência, mudanças nas rotinas de trabalho, com média igual a 3,62 e desvio padrão de 1,69.

Diferentemente dos resultados verificados na avaliação do Grupo A, no Grupo B o desvio padrão de cada questão apresentou índices altos se situando entre 1,69 e 2,03, o que demonstra grande dispersão nas respostas dos participantes dessa amostra.

O fato que pode ter contribuído para essa diferença dos resultados entre as avaliações dos dois grupos pode estar relacionado com a natureza de cada evento instrucional. Enquanto o curso técnicas de segurança para autoridades tem relação direta com as atividades desempenhadas pelos participantes em seu cargo, agentes de segurança; o curso de sistemas informatizados é restrito a dois sistemas que correspondem a uma das atividades executadas pelos servidores, dentre várias desempenhadas no cargo. Além disso, os treinandos nos sistemas informatizados detinham certo conhecimento sobre esses sistemas, tendo em vista que foi implantado antes do evento instrucional.

De acordo com Freitas et al. (2006), o impacto é o resultado positivo da transferência de aprendizagem, e só pode ser observado quando a pessoa treinada aplica os CHAs adquiridos e quando essa aplicação proporciona melhorias na sua vida pessoal ou profissional.

Conforme apresentado nessa seção, a avaliação de impacto do treinamento no trabalho para os grupos A e B da amostra apresentaram médias gerais iguais a 5,99 e 4,65, respectivamente, e desvios padrão, em relação às médias de cada item, inferiores a $1,0 \quad(0,25$ e 0,50$)$. Nesse sentido, verificou-se que os treinandos 
perceberem impacto positivo no desempenho no cargo após participarem dos eventos de treinamento, sendo maior no Grupo A da amostra.

\subsection{Avaliação de Percepção de Suporte Organizacional}

Esta seção trará os resultados descritivos relativos à avaliação de percepção suporte organizacional, que se refere a um dos objetivos específicos deste estudo.

O questionário utilizado para coletar os dados relativos a suporte, conforme descrito no capítulo sobre métodos e técnicas de pesquisa, foi a escala de Percepção de Suporte Organizacional elaborada por Oliveira-Castro, Pilati e Borges-Andrade (1999). Através desse instrumento, os empregados ou funcionários expressam suas opiniões sobre o comprometimento da organização para com eles no âmbito de quatro fatores, a saber: Fator 1: Gestão de Desempenho; Fator 2: Carga de Trabalho; Fator 3: Suporte Material; e Fator 4: Práticas Organizacionais de Ascensão, Promoção e Salários. O Fator Único, soma das questões dos quatro fatores que compõem a escala, possui 52 itens, dentre eles, os itens 2, 10, 13, 16, 19 e 41 somente fazem parte deste fator, ou seja, não integrando nenhum dos fatores relacionados acima. Os itens 15, 23, 43, 46 e 51 integram mais de um fator. Por fim, os itens 1, 3, 8, 9, 21, 25, 29, 30, 32, 42, 43 e 46 possuem carga fatorial negativa, para a criação do escore fatorial, tais questões tiveram seu sentido invertido.

Os respondentes avaliaram cada item do questionário com base numa escala do tipo Likert de 5 pontos, onde 5 corresponde a "concordo totalmente" com a afirmativa e 1, "discordo totalmente" da afirmativa.

As respostas das amostras foram submetidas a análises estatísticas descritivas onde foram calculadas as médias, os desvios padrão e as freqüências de cada item. As questões, em cada fator, estão organizadas em ordem decrescente de importância, ou seja, dos itens mais importantes do fator para os menos importantes. Essa seção está dividida em cinco subseções sendo que, as quatro primeiras correspondem à descrição dos resultados de cada um dos fatores da escala de 
suporte organizacional e a quinta, traz o resumo dos principais resultados encontrados.

\subsubsection{Fator 1: Gestão de desempenho}

Nesta subseção são apresentados os resultados relativos ao primeiro fator, gestão de desempenho, composta por treze itens relativos às opiniões dos trabalhadores sobre as práticas organizacionais de gerenciamento do desempenho do funcionário: estabelecimento de metas, valorização de novas idéias, conhecimento de dificuldades na execução eficaz das tarefas organizacionais de gerenciamento do desempenho dos funcionários, como estabelecimento de metas, valorização de novas idéias, conhecimento de dificuldades associadas à execução eficaz das tarefas e esforço organizacional de atualização de seus colaboradores ou empregados em face das novas tecnologias e processos de trabalho.

O item 29 desse fator possui carga fatorial negativa e teve seu sentido invertido para a criação do escore fatorial.

A Tabela 3 mostra as médias, desvios padrão e os percentuais de concentração de respostas nos escores 1, 2, 3, 4 e 5 do Grupo A da amostra.

Tabela 3: Fator 1 - Grupo A

\begin{tabular}{|c|c|c|c|c|c|c|c|}
\hline \multirow{2}{*}{ Item do Questionário } & \multirow{2}{*}{ Média } & \multirow{2}{*}{ DP } & \multicolumn{5}{|c|}{ \% Respostas } \\
\hline & & & 1 & 2 & 3 & 4 & 5 \\
\hline $\begin{array}{l}\text { 6. Esta organização valoriza novas idéias e propostas } \\
\text { criativas de trabalho feitas pelos funcionários. }\end{array}$ & 3,10 & 1,29 & 15 & 20 & 15 & 40 & 10 \\
\hline $\begin{array}{l}\text { 49. Aqui, o funcionário pode opinar decisivamente na } \\
\text { resolução de problemas de trabalho. }\end{array}$ & 2,35 & 1,14 & 30 & 25 & 25 & 20 & \\
\hline $\begin{array}{l}\text { 40. Esta organização consulta os funcionários antes de } \\
\text { promover mudanças nos produtos e na organização. }\end{array}$ & 2,90 & 1,17 & 15 & 15 & 45 & 15 & 10 \\
\hline $\begin{array}{l}\text { 7. Esta organização, ao julgar o desempenho do } \\
\text { funcionário, leva em conta o esforço que ele despendeu } \\
\text { para atingir os resultados esperados. }\end{array}$ & 3,40 & 1,27 & 15 & 5 & 20 & 45 & 15 \\
\hline $\begin{array}{l}\text { 20. Esta organização procura conhecer as dificuldades } \\
\text { encontradas pelo funcionário no desempenho de suas } \\
\text { atividades. }\end{array}$ & 2,95 & 1,43 & 25 & 10 & 25 & 25 & 15 \\
\hline $\begin{array}{l}\text { 26. Nesta organização, o funcionário recebe todas as } \\
\text { orientações e informações necessárias à execução eficaz } \\
\text { das suas atividades. }\end{array}$ & 3,45 & 1,23 & & 35 & 10 & 30 & 25 \\
\hline $\begin{array}{l}\text { 31. Esta organização mantém coerência entre diretrizes, } \\
\text { discursos e ações que realiza. }\end{array}$ & 3,10 & 1,17 & 10 & 20 & 30 & 30 & 10 \\
\hline $\begin{array}{l}\text { 15. Esta organização preocupa-se em dinamizar e } \\
\text { modernizar constantemente os processos de trabalho. }\end{array}$ & 3,25 & 1,21 & 5 & 30 & 15 & 35 & 15 \\
\hline 51. Esta organização toma as providências necessárias & 3,55 & 1,00 & 5 & 5 & 35 & 40 & 15 \\
\hline
\end{tabular}




\begin{tabular}{|c|c|c|c|c|c|c|c|}
\hline \multirow{2}{*}{ Item do Questionário } & \multirow{2}{*}{ Média } & \multirow{2}{*}{ DP } & \multicolumn{5}{|c|}{ \% Respostas } \\
\hline & & & 1 & 2 & 3 & 4 & 5 \\
\hline $\begin{array}{l}\text { para sanar dificuldades ou remover obstáculos ao } \\
\text { desempenho eficaz. }\end{array}$ & & & & & & & \\
\hline $\begin{array}{l}\text { 29. Esta organização desvaloriza os esforços feitos pelos } \\
\text { funcionários, interrompendo freqüentemente projetos de } \\
\text { trabalho em andamento. }\end{array}$ & 3,50 & 0,89 & 20 & 15 & 60 & 5 & \\
\hline $\begin{array}{l}\text { 23. Esta organização preocupa-se em manter seus } \\
\text { funcionários atualizados quanto às novidades } \\
\text { tecnológicas que afetam seu desempenho funcional. }\end{array}$ & 3,05 & 1,50 & 25 & 10 & 20 & 25 & 20 \\
\hline $\begin{array}{l}\text { 4. Aqui, o funcionário sabe exatamente o que deve fazer } \\
\text { e quais são as metas de desempenho esperadas. }\end{array}$ & 4,40 & 0,75 & & 5 & & 45 & 50 \\
\hline $\begin{array}{l}\text { 18. Esta organização preocupa-se em proporcionar o } \\
\text { desenvolvimento das capacidades do funcionário, } \\
\text { oferecendo-lhe tarefas desafiadoras. }\end{array}$ & 2,80 & 1,32 & 25 & 15 & 20 & 35 & 5 \\
\hline Total & 3,22 & 0,49 & 13 & 17 & 24 & 30 & 16 \\
\hline
\end{tabular}

Fonte: Dados da pesquisa

Os resultados do Grupo A da amostra mostram que dos treze itens que compõem o fator relativo à percepção de gestão de desempenho apenas um obteve média acima de 4; a média dos demais itens variou de 3,55 a 2,35; oito itens alcançaram médias acima de $3(3,55$ a 3,05), dentre eles, somente três encontram-se entre os 6 mais importantes. Somente dois itens tiveram desvio padrão abaixo de 1,00 $(0,75$ e 0,89), os demais itens tiveram desvios padrão situando-se entre 1,00 e 1,50. O valor obtido pelo cálculo do escore médio dos itens do fator ficou em 3,22 (DP 0,49).

O item que apresentou melhor resultado foi o 4. Aqui, o funcionário sabe exatamente o que deve fazer e quais são as metas de desempenho esperadas, foi a questão mais bem avaliada e a única a obter média acima de $4(4,40)$. O desvio padrão desse item correspondeu ao menor observado $(0,75)$, tal questão concentrou $95 \%$ das respostas nos escores de concordância (4 e 5). No entanto, de acordo com a ordem de importância dos itens, ele aparece, apenas, na penúltima colocação. Outro item que obteve uma boa avaliação foi o 51. Esta organização toma as providências necessárias para sanar dificuldades ou remover obstáculos ao desempenho eficaz, com média igual a 3,55 (DP 1,00). A concentração dos escores de concordância ficou em 55\%, no entanto, 35\% das respostas foram neutras.

Em contrapartida, os itens 49. Aqui, o funcionário pode opinar decisivamente na resolução de problemas de trabalho e 18. Esta organização preocupa-se em proporcionar o desenvolvimento das capacidades do funcionário, oferecendoIhe tarefas desafiadoras. Apresentaram as piores avaliações, com médias iguais a 2,35 e 2,80, respectivamente. Os desvios padrão desses itens situaram-se em 1,14 
e 1,32, respectivamente, ambos apresentaram maior freqüência das respostas nos escores de discordância, o que corrobora tendência para as médias obtidas.

A Tabela 4 traz os resultados descritivos do Grupo B da amostra.

Tabela 4: Fator 1 - Grupo B

\begin{tabular}{|c|c|c|c|c|c|c|c|}
\hline \multirow{2}{*}{ Item do Questionário } & \multirow{2}{*}{ Média } & \multirow{2}{*}{ DP } & \multicolumn{5}{|c|}{ \% Respostas } \\
\hline & & & 1 & 2 & 3 & 4 & 5 \\
\hline $\begin{array}{l}\text { 6. Esta organização valoriza novas idéias e propostas } \\
\text { criativas de trabalho feitas pelos funcionários. }\end{array}$ & 3,03 & 1,30 & 13,5 & 24,3 & 24,3 & 21,6 & 16,2 \\
\hline $\begin{array}{l}\text { 49. Aqui, o funcionário pode opinar decisivamente na } \\
\text { resolução de problemas de trabalho. }\end{array}$ & 2,49 & 1,12 & 13,5 & 24,3 & 24,3 & 21,6 & 16,2 \\
\hline $\begin{array}{l}\text { 40. Esta organização consulta os funcionários antes de } \\
\text { promover mudanças nos produtos e na organização. }\end{array}$ & 2,35 & 1,25 & 35,1 & 18,9 & 27 & 13,5 & 5,4 \\
\hline $\begin{array}{l}\text { 7. Esta organização, ao julgar o desempenho do } \\
\text { funcionário, leva em conta o esforço que ele despendeu } \\
\text { para atingir os resultados esperados. }\end{array}$ & 3,00 & 1,25 & 16,2 & 18,9 & 21,6 & 35,1 & 8,1 \\
\hline $\begin{array}{l}\text { 20. Esta organização procura conhecer as dificuldades } \\
\text { encontradas pelo funcionário no desempenho de suas } \\
\text { atividades. }\end{array}$ & 2,92 & 1,26 & 18,9 & 16,2 & 27 & 29,7 & 8,1 \\
\hline $\begin{array}{l}\text { 26. Nesta organização, o funcionário recebe todas as } \\
\text { orientações e informações necessárias à execução eficaz } \\
\text { das suas atividades. }\end{array}$ & 2,76 & 1,30 & 21,6 & 24,3 & 18,9 & 27 & 8,1 \\
\hline $\begin{array}{l}\text { 31. Esta organização mantém coerência entre diretrizes, } \\
\text { discursos e ações que realiza. }\end{array}$ & 3,11 & 1,07 & 10,8 & 13,5 & 35,1 & 35,1 & 5,4 \\
\hline $\begin{array}{l}\text { 15. Esta organização preocupa-se em dinamizar e } \\
\text { modernizar constantemente os processos de trabalho. }\end{array}$ & 2,92 & 1,32 & 16,2 & 27 & 18,9 & 24,3 & 13,5 \\
\hline $\begin{array}{l}\text { 51. .Esta organização toma as providências necessárias } \\
\text { para sanar dificuldades ou remover obstáculos ao } \\
\text { desempenho eficaz. }\end{array}$ & 3,03 & 1,04 & 8,1 & 21,6 & 35,1 & 29,7 & 5,4 \\
\hline $\begin{array}{l}\text { 29. Esta organização desvaloriza os esforços feitos pelos } \\
\text { funcionários, interrompendo freqüentemente projetos de } \\
\text { trabalho em andamento. }\end{array}$ & 3,11 & 1,20 & 18,9 & 10,8 & 40,5 & 21,6 & 8,1 \\
\hline $\begin{array}{l}\text { 23. Esta organização preocupa-se em manter seus } \\
\text { funcionários atualizados quanto às novidades tecnológicas } \\
\text { que afetam seu desempenho funcional. }\end{array}$ & 2,92 & 1,23 & 13,5 & 27 & 24,3 & 24,3 & 10,8 \\
\hline $\begin{array}{l}\text { 4. Aqui, o funcionário sabe exatamente o que deve fazer e } \\
\text { quais são as metas de desempenho esperadas. }\end{array}$ & 3,57 & 1,34 & 8,1 & 18,9 & 13,5 & 27 & 32,4 \\
\hline $\begin{array}{l}\text { 18. Esta organização preocupa-se em proporcionar o } \\
\text { desenvolvimento das capacidades do funcionário, } \\
\text { oferecendo-lhe tarefas desafiadoras. }\end{array}$ & 2,62 & 1,11 & 18,9 & 27 & 29,7 & 21,6 & 2,7 \\
\hline Total & 2,91 & 0,31 & 16 & 22 & 27 & 24 & 11 \\
\hline
\end{tabular}

Fonte: Dados da pesquisa

Em relação ao Grupo B da amostra, a média dos 13 itens situou-se entre 3,57 e 2,35; dos cinco itens com média acima de 3 , apenas dois encontram-se entre os seis mais importantes; foi alta a concentração das respostas no item neutro, $27 \%$ do total das respostas. O valor obtido pelo cálculo do escore médio dos itens desse fator ficou abaixo de 3 (2,91). Assim como na avaliação do Grupo A, essa amostra apresentou grande dispersão nas respostas dos participantes situando-se entre 1,07 e 1,34. No que se refere ao desvio padrão das médias dos itens, este apresentou 
valor baixo $(0,31)$, o que significa que não houve grande variação entre as médias das questões desse fator.

O item que apresentou melhor resultado em relação ao conjunto de questões desse fator, assim como na avaliação do Grupo A, foi o 4. Aqui, o funcionário sabe exatamente o que deve fazer e quais são as metas de desempenho esperadas, com média igual a 3,57 e desvio padrão de 1,34.

No que se refere às piores médias, destacam-se o item 40. Esta organização consulta os funcionários antes de promover mudanças nos produtos e na organização, com média igual a 2,35 ( $D P=1,25)$. Esse item, terceiro mais importante, concentrou mais de $60 \%$ das respostas nos escores de discordância (1 e 2). E o item 49. Aqui, o funcionário pode opinar decisivamente na resolução de problemas de trabalho, com média 2,49 e desvio padrão de 1,12. Verifica-se que esse item também aparece com uma das piores avaliações no Grupo A da amostra, indicando que, na opinião da maioria dos servidores dos dois grupos, o órgão não costuma valorizar a opinião de seus colaboradores.

\subsubsection{Fator 2: Carga de trabalho}

Esta subseção traz os resultados relativos ao segundo fator da escala, carga de trabalho, composto por 9 itens. Nesse fator os trabalhadores avaliam o suporte no que se refere às exigências e à sobrecarga de tarefas atribuídas aos funcionários, devido às altas demandas de produção.

A seguir, na Tabela 5, são apresentadas as médias, desvios padrão e os percentuais de concentração de respostas nos escores 1, 2, 3, 4 e 5 do Grupo A da amostra.

Tabela 5: Fator 2 - Grupo A

\begin{tabular}{|c|c|c|c|c|c|c|c|}
\hline \multirow{2}{*}{ Item do Questionário } & \multirow{2}{*}{ Média } & \multirow{2}{*}{ DP } & \multicolumn{5}{|c|}{ \% Respostas } \\
\hline & & & 1 & 2 & 3 & 4 & 5 \\
\hline $\begin{array}{l}\text { 33. Aqui, a carga de trabalho é excessiva, levando o } \\
\text { funcionário ao esgotamento físico e mental. }\end{array}$ & 2,25 & 1,71 & 60 & 5 & 5 & 10 & 20 \\
\hline $\begin{array}{l}\text { 37. Nesta organização, os funcionários são obrigados a fazer } \\
\text { horas-extras constantemente, sobrando pouco tempo para } \\
\text { estarem em casa com seus familiares. }\end{array}$ & 1,70 & 1,38 & 75 & 5 & 5 & 5 & 10 \\
\hline $\begin{array}{l}\text { 45. Esta organização suga a energia do funcionário, } \\
\text { obrigando-o a trabalhar um número excessivo de horas, sem }\end{array}$ & 2,05 & 1,61 & 65 & 5 & 5 & 10 & 15 \\
\hline
\end{tabular}




\begin{tabular}{|c|c|c|c|c|c|c|c|}
\hline \multirow{2}{*}{ Item do Questionário } & \multirow{2}{*}{ Média } & \multirow{2}{*}{ DP } & \multicolumn{5}{|c|}{ \% Respostas } \\
\hline & & & 1 & 2 & 3 & 4 & 5 \\
\hline pagar horas-extras ou aumentar o número de funcionários. & & & & & & & \\
\hline $\begin{array}{l}\text { 34. Esta organização sobrecarrega de trabalho os seus } \\
\text { melhores funcionários. }\end{array}$ & 2,50 & 1,54 & 40 & 20 & & 30 & 10 \\
\hline $\begin{array}{l}\text { 43. Esta organização só se interessa pela produção, deixando } \\
\text { de oferecer condições saudáveis de trabalho. }\end{array}$ & 1,85 & 1,27 & 55 & 25 & 10 & & 10 \\
\hline $\begin{array}{l}\text { 50. Esta organização determina prazos irrealistas para a } \\
\text { entrega de trabalhos, sem se preocupar se estão disponíveis } \\
\text { os recursos financeiros, materiais e humanos necessários a } \\
\text { sua execução. }\end{array}$ & 2,00 & 1,12 & 45 & 20 & 30 & & 5 \\
\hline $\begin{array}{l}\text { 38. Esta organização coloca os funcionários em locais que } \\
\text { não se ajustam às suas características pessoais e capacidades } \\
\text { profissionais. }\end{array}$ & 1,90 & 1,25 & 60 & 5 & 25 & 5 & 5 \\
\hline $\begin{array}{l}\text { 24. Esta organização chama a atenção dos funcionários por } \\
\text { pequenas falhas ou erros, ressaltando mais os aspectos } \\
\text { negativos do que os positivos do seu desempenho }\end{array}$ & 2,90 & 1,21 & 20 & 10 & 35 & 30 & 5 \\
\hline $\begin{array}{l}\text { 14. Esta organização desconsidera os interesses pessoais do } \\
\text { funcionário, ao tomar decisões administrativas (como } \\
\text { transferências, por exemplo) relativas a ele. }\end{array}$ & 2,90 & 1,07 & 10 & 25 & 35 & 25 & 5 \\
\hline Total & 2,23 & 0,45 & 48 & 13 & 17 & 13 & 9 \\
\hline
\end{tabular}

Fonte: Dados da pesquisa

A partir dos dados acima, verifica-se que nenhum dos 9 itens que compõem o fator relativo à percepção de carga de trabalho obteve média superior a 3; as médias variaram de 2,90 a 1,70 ; os primeiros sete itens tiveram $60 \%$ ou mais das respostas concentradas nos escores 1 e 2. Os valores dos desvios padrão se situaram entre 1,07 a 1,71. O valor obtido pelo cálculo do escore médio dos itens do fator ficou em 2,23 (DP 0,45).

É importante destacar uma peculiaridade desse fator, todos os itens que o compõem são analisados da seguinte forma: quanto maior for a concentração dos itens nas afirmativas de discordância, mais bem avaliados eles serão. Vejamos os dois primeiros itens: 33. Aqui, a carga de trabalho é excessiva, levando o funcionário ao esgotamento físico e mental, com média 2,25 e concentração de $65 \%$ das respostas nos escores 1 e 2; e o 37. Nesta organização, os funcionários são obrigados a fazer horas-extras constantemente, sobrando pouco tempo para estarem em casa com seus familiares, com média igual a 1,70 e concentração de $80 \%$ nos escores de discordância. A partir desses dados, infere-se que, de acordo com a percepção da maioria dos respondentes, essa organização não sobrecarrega de trabalho os seus funcionários.

Os resultados relativos ao Grupo B da amostra são apresentados na Tabela 6 abaixo. 
Tabela 6: Fator 2 - Grupo B

\begin{tabular}{|c|c|c|c|c|c|c|c|}
\hline \multirow{2}{*}{ Item do Questionário } & \multirow{2}{*}{ Média } & \multirow{2}{*}{ DP } & \multicolumn{5}{|c|}{$\%$ Respostas } \\
\hline & & & 1 & 2 & 3 & 4 & 5 \\
\hline $\begin{array}{l}\text { 33. Aqui, a carga de trabalho é excessiva, levando o } \\
\text { funcionário ao esgotamento físico e mental. }\end{array}$ & 3,16 & 1,34 & 16,2 & 13,5 & 27 & 24,3 & 18,9 \\
\hline $\begin{array}{l}\text { 37. Nesta organização, os funcionários são obrigados a fazer } \\
\text { horas-extras constantemente, sobrando pouco tempo para } \\
\text { estarem em casa com seus familiares. }\end{array}$ & 1,81 & 1,20 & 62,2 & 8,1 & 21,6 & 2,7 & 5,4 \\
\hline $\begin{array}{l}\text { 45. Esta organização suga a energia do funcionário, } \\
\text { obrigando-o a trabalhar um número excessivo de horas, sem } \\
\text { pagar horas-extras ou aumentar o número de funcionários. }\end{array}$ & 2,76 & 1,48 & 27 & 21,6 & 18,9 & 13,5 & 18,9 \\
\hline $\begin{array}{l}\text { 34. Esta organização sobrecarrega de trabalho os seus } \\
\text { melhores funcionários. }\end{array}$ & 3,59 & 1,40 & 16,2 & 2,7 & 18,9 & 29,7 & 32,4 \\
\hline $\begin{array}{l}\text { 43. Esta organização só se interessa pela produção, deixando } \\
\text { de oferecer condições saudáveis de trabalho. }\end{array}$ & 2,51 & 1,28 & 29,7 & 21,6 & 21,6 & 21,6 & 5,4 \\
\hline $\begin{array}{l}\text { 50. Esta organização determina prazos irrealistas para a } \\
\text { entrega de trabalhos, sem se preocupar se estão disponíveis } \\
\text { os recursos financeiros, materiais e humanos necessários a } \\
\text { sua execução. }\end{array}$ & 2,78 & 1,40 & 24,3 & 16,2 & 35,1 & 5,4 & 18,9 \\
\hline $\begin{array}{l}\text { 38. Esta organização coloca os funcionários em locais que } \\
\text { não se ajustam às suas características pessoais e capacidades } \\
\text { profissionais. }\end{array}$ & 2,76 & 1,40 & 24,3 & 24,3 & 16,2 & 21,6 & 13,5 \\
\hline $\begin{array}{l}\text { 24. Esta organização chama a atenção dos funcionários por } \\
\text { pequenas falhas ou erros, ressaltando mais os aspectos } \\
\text { negativos do que os positivos do seu desempenho }\end{array}$ & 2,84 & 1,24 & 18,9 & 16,2 & 37,8 & 16,2 & 10,8 \\
\hline $\begin{array}{l}\text { 14. Esta organização desconsidera os interesses pessoais do } \\
\text { funcionário, ao tomar decisões administrativas (como } \\
\text { transferências, por exemplo) relativas a ele. }\end{array}$ & 2,84 & 1,01 & 10,8 & 18,9 & 54,1 & 8,1 & 8,1 \\
\hline Total & 2,78 & 0,48 & 25 & 16 & 28 & 16 & 15 \\
\hline
\end{tabular}

Fonte: Dados da pesquisa

Os resultados do Grupo B mostram que as médias variaram de 3,59 a 1,81; dois itens alcançaram médias acima de 3 (3,59 e 3,16); um item obteve mais de $70 \%$ das respostas concentradas nos escores 1 e 2 ; quase $30 \%$ do total das respostas concentraram-se na afirmativa neutra, onde o participante afirma "não concordar, nem discordar" da afirmativa avaliada. Os valores dos desvios padrão se situaram entre 1,01 a 1,48. O valor obtido pelo cálculo do escore médio dos itens do fator ficou em 2,78 (DP 0,48).

Os dois itens com maiores médias foram: 34. Esta organização sobrecarrega de trabalho os seus melhores funcionários com média igual a 3,59 (DP 1,40), onde mais de $60 \%$ das respostas concentraram-se nos escores de concordância; e o item 33. Aqui, a carga de trabalho é excessiva, levando o funcionário ao esgotamento físico e mental, primeiro colocado no quesito importância, com média 3,16 (DP 1,34), com pouco mais de $40 \%$ das respostas nos escores de concordância. Através desses dados e, de acordo com a peculiaridade do fator carga de trabalho descrita anteriormente, observa-se que uma parte considerável 
dos participantes desse grupo possui uma percepção negativa, a respeito da organização, no que se refere à distribuição das tarefas entre seus colaboradores e em relação à quantidade de trabalho. Os resultados desses itens expressam a atual situação do judiciário brasileiro que por acumular grande quantidade de trabalho acaba sobrecarregando seus funcionários.

Verifica-se que as opiniões dos dois grupos divergem em relação aos dois itens citados acima, a especificidade das funções de cada amostra pode explicar a diferença encontrada, isso porque o Grupo B desempenha tarefas diretamente relacionadas com a atividade fim do órgão (serviço jurisdicional), que no contexto atual acumula trabalho, já os integrantes do Grupo B desempenham atividades, apenas, de apoio a esse serviço.

\subsubsection{Fator 3: Suporte material}

Os resultados do terceiro fator, suporte material, são descritos nesta subseção. Esse fator é composto por 17 itens que colhem à opinião da amostra sobre a disponibilidade, adequação, suficiência e qualidade dos recursos materiais e financeiros fornecidos pela organização para apoiar a execução eficaz das tarefas.

Os itens 1, 30, 32, 35, 42 e 43 desse fator possuem carga fatorial negativa e tiveram seus sentidos invertidos para a criação do escore fatorial.

A Tabela 7 mostra as médias, desvios-padrão e os percentuais de concentração de respostas nos escores 1, 2, 3, 4 e 5 do Grupo A.

Tabela 7: Fator 3 - Grupo A

\begin{tabular}{|c|c|c|c|c|c|c|c|}
\hline \multirow{2}{*}{ Item do Questionário } & \multirow{2}{*}{ Média } & \multirow{2}{*}{ DP } & \multicolumn{5}{|c|}{ \% Respostas } \\
\hline & & & $\mathbf{1}$ & 2 & 3 & 4 & 5 \\
\hline $\begin{array}{l}\text { 28. Esta organização oferece equipamentos, máquinas, } \\
\text { materiais e equipamentos compatíveis com o nível de } \\
\text { exigência esperado dos resultados. }\end{array}$ & 3,80 & 1,06 & & 15 & 20 & 35 & 30 \\
\hline $\begin{array}{l}\text { 27. Esta organização efetua regularmente a manutenção de } \\
\text { máquinas e equipamentos de trabalho, garantindo que } \\
\text { estejam em plenas condições de uso. }\end{array}$ & 4,25 & 1,02 & & 10 & 10 & 25 & 55 \\
\hline $\begin{array}{l}\text { 52. Esta organização esforça-se para adquirir equipamentos } \\
\text { modernos de trabalho que agilizam a execução das tarefas. }\end{array}$ & 3,05 & 1,43 & 25 & 5 & 25 & 30 & 15 \\
\hline $\begin{array}{l}\text { 30. Aqui as ferramentas de trabalho (computadores, } \\
\text { máquinas, etc.) são de má qualidade. }\end{array}$ & 3,75 & 1,33 & 35 & 35 & 10 & 10 & 10 \\
\hline $\begin{array}{l}\text { 5. Esta organização oferece locais de trabalho com móveis, } \\
\text { equipamentos e materiais em quantidade suficiente. }\end{array}$ & 2,40 & 1,19 & 30 & 20 & 35 & 10 & 5 \\
\hline $\begin{array}{l}\text { 23. Esta organização preocupa-se em manter seus } \\
\text { funcionários atualizados quanto as novidades tecnológicas } \\
\text { que afetam seu funcionário. }\end{array}$ & 3,05 & 1,50 & 25 & 10 & 20 & 25 & 20 \\
\hline
\end{tabular}




\begin{tabular}{|c|c|c|c|c|c|c|c|}
\hline \multirow{2}{*}{ Item do Questionário } & \multirow{2}{*}{ Média } & \multirow{2}{*}{ DP } & \multicolumn{5}{|c|}{ \% Respostas } \\
\hline & & & 1 & 2 & 3 & 4 & 5 \\
\hline $\begin{array}{l}\text { 12. Esta organização procura melhorar constantemente as } \\
\text { condições físicas dos locais de trabalho. }\end{array}$ & 2,60 & 1,23 & 20 & 30 & 30 & 10 & 10 \\
\hline $\begin{array}{l}\text { 42. Aqui, apesar das reclamações dos funcionários, os locais } \\
\text { de trabalho estão sempre sujos. }\end{array}$ & 4,00 & 1,30 & 50 & 20 & 20 & & 10 \\
\hline $\begin{array}{l}\text { 32. Aqui, os ambientes de trabalho são inadequados ao } \\
\text { desempenho eficaz das atividades (salas mal iluminadas, } \\
\text { com pouca ventilação. Pequenas demais, com móveis } \\
\text { incompatíveis com a execução correta das tarefas, etc.) }\end{array}$ & 2,85 & 1,60 & 25 & 10 & 20 & 15 & 30 \\
\hline $\begin{array}{l}\text { 22. Esta organização oferece todo o suporte financeiro extra } \\
\text { necessário a execução das tarefas, tais como chamadas } \\
\text { telefônicas de longa distancia, viagens, contratação de } \\
\text { pessoal temporário para auxiliar no trabalho e outros. }\end{array}$ & 2,35 & 1,53 & 45 & 15 & 15 & 10 & 15 \\
\hline $\begin{array}{l}\text { 39. Nesta organização, os recursos financeiros necessários a } \\
\text { realização das tarefas são liberados sempre a tempo de } \\
\text { terminar um trabalho dentro do prazo. }\end{array}$ & 3,15 & 1,09 & 10 & 15 & 30 & 40 & 5 \\
\hline $\begin{array}{l}\text { 1. Esta organização raramente fornece todos os recursos } \\
\text { materiais necessários ao bom desempenho das tarefas. }\end{array}$ & 2,85 & 1,14 & 5 & 35 & 5 & 50 & 5 \\
\hline $\begin{array}{l}35 \text { Esta organização e lenta demais na aquisição e na } \\
\text { implementação do uso de equipamentos de segurança no } \\
\text { trabalho. }\end{array}$ & 3,40 & 0,99 & 10 & 40 & 35 & 10 & 5 \\
\hline $\begin{array}{l}\text { 51. Esta organização toma as providências necessárias para } \\
\text { sanar dificuldades ou remover obstáculos ao desempenho } \\
\text { eficaz. }\end{array}$ & 3,55 & 1,00 & 5 & 5 & 35 & 40 & 15 \\
\hline $\begin{array}{l}\text { 15. Esta organização preocupa-se em dinamizar e modernizar } \\
\text { constantemente os processos de trabalho. }\end{array}$ & 3,25 & 1,21 & 5 & 30 & 15 & 35 & 15 \\
\hline $\begin{array}{l}\text { 47. Esta organização investe na capacitação e aprimoramento } \\
\text { profissional dos seus funcionários, oferecendo-lhes } \\
\text { constantemente treinamentos específicos segundo a área de } \\
\text { atuação de cada um. }\end{array}$ & 4,15 & 0,81 & & 5 & 10 & 50 & 35 \\
\hline $\begin{array}{l}\text { 43. Esta organização só se interessa pela produção deixando } \\
\text { de oferecer condições saudáveis de trabalho. }\end{array}$ & 4,15 & 1,27 & 55 & 25 & 10 & & 10 \\
\hline Total & 3,33 & 0,62 & 14 & 14 & 20 & 28 & 24 \\
\hline
\end{tabular}

Fonte: Dados da pesquisa

Os resultados do Grupo A mostram que as médias situaram-se entre 4,25 e 2,35; dos 17 itens, quatro obtiveram médias acima de 4 (4,25 a 4,00), destes, apenas um encontra-se entre os seis mais importantes; oito alcançaram médias entre 3,80 e 3,05; e cinco ficaram com média abaixo de $3(2,85$ a 2,35). O escore médio dos itens desse fator situou-se em 3,33. Os valores dos desvios padrão ficaram entre 0,99 e 1,60. Em relação ao desvio padrão das médias dos itens, este apresentou o valor de 0,62 .

Dos 17 itens do fator, 3 concentraram mais de 60\% das respostas nos escores de concordância (itens 28, 27 e 47), dois deles correspondem ao primeiro e segundo mais importantes do fator de suporte material; 4 itens obtiveram $60 \%$ ou mais das respostas concentradas nos escores de discordância (itens 30, 22, 42 e 43), dentre eles, 3 correspondem a questões que quanto maior o número de escores tiverem concentrados na afirmativa de discordância, mais bem avaliada estará a percepção de suporte na organização. 
De acordo com o conjunto de questões que compõem esse fator, os itens com melhores resultados foram: 27. Esta organização efetua regularmente a manutenção de máquinas e equipamentos de trabalho, garantindo que estejam em plenas condições de uso, com média igual a 4,25 e desvio padrão de 1,02. Esse item concentrou $80 \%$ das respostas nos escores 4 e 5 . E o item 47. Esta organização investe na capacitação e aprimoramento profissional dos seus funcionários, oferecendo-Ihes constantemente treinamentos específicos segundo a área de atuação de cada um, com média de 4,15 (DP 0,81).

O item 5. Esta organização oferece locais de trabalho com móveis, equipamentos e materiais em quantidade suficiente, obteve a pior média, 2,40 e o desvio padrão situou-se em 1,19.

A Tabela 8 traz os resultados descritivos do Grupo B da amostra.

Tabela 8: Fator 3 - Grupo B

\begin{tabular}{|c|c|c|c|c|c|c|c|}
\hline \multirow{2}{*}{ Item do Questionário } & \multirow{2}{*}{ Média } & \multirow{2}{*}{$\mathbf{D P}$} & \multicolumn{5}{|c|}{ \% Respostas } \\
\hline & & & $\mathbf{1}$ & 2 & 3 & 4 & 5 \\
\hline $\begin{array}{l}\text { 28. Esta organização oferece equipamentos, máquinas, } \\
\text { materiais e equipamentos compatíveis com o nível de } \\
\text { exigência esperado dos resultados. }\end{array}$ & 3,38 & 1,34 & 8,1 & 27 & 8,1 & 32,4 & 24,3 \\
\hline $\begin{array}{l}\text { 27. Esta organização efetua regularmente a manutenção de } \\
\text { máquinas e equipamentos de trabalho, garantindo que } \\
\text { estejam em plenas condições de uso. }\end{array}$ & 3,38 & 1,26 & 8,1 & 18,9 & 21,6 & 29,7 & 21,6 \\
\hline $\begin{array}{l}\text { 52. Esta organização esforça-se para adquirir equipamentos } \\
\text { modernos de trabalho que agilizam a execução das tarefas. }\end{array}$ & 3,16 & 1,12 & 8,1 & 18,9 & 32,4 & 29,7 & 10,8 \\
\hline $\begin{array}{l}\text { 30. Aqui as ferramentas de trabalho (computadores, } \\
\text { máquinas, etc.) são de má qualidade. }\end{array}$ & 3,81 & 1,29 & 36,1 & 27,8 & 16,7 & 13,9 & 5,6 \\
\hline $\begin{array}{l}\text { 5. Esta organização oferece locais de trabalho com móveis, } \\
\text { equipamentos e materiais em quantidade suficiente. }\end{array}$ & 3,95 & 1,15 & 5,4 & 8,1 & 10,8 & 37,8 & 37,8 \\
\hline $\begin{array}{l}\text { 23. Esta organização preocupa-se em manter seus } \\
\text { funcionários atualizados quanto as novidades tecnológicas } \\
\text { que afetam seu funcionário. }\end{array}$ & 2,92 & 1,23 & 13,5 & 27 & 24,3 & 24,3 & 10,8 \\
\hline $\begin{array}{l}\text { 12. Esta organização procura melhorar constantemente as } \\
\text { condições físicas dos locais de trabalho. }\end{array}$ & 3,22 & 1,06 & 2,7 & 27 & 27 & 32,4 & 10,8 \\
\hline $\begin{array}{l}\text { 42. Aqui, apesar das reclamações dos funcionários, os } \\
\text { locais de trabalho estão sempre sujos. }\end{array}$ & 4,05 & 1,05 & 43,2 & 29,7 & 18,9 & 5,4 & 2,7 \\
\hline $\begin{array}{l}\text { 32. Aqui, os ambientes de trabalho são inadequados ao } \\
\text { desempenho eficaz das atividades (salas mal iluminadas, } \\
\text { com pouca ventilação. Pequenas demais, com móveis } \\
\text { incompatíveis com a execução correta das tarefas, etc.) }\end{array}$ & 3,35 & 1,53 & 35,1 & 16,2 & 13,5 & 18,9 & 16,2 \\
\hline $\begin{array}{l}\text { 22. Esta organização oferece todo o suporte financeiro } \\
\text { extra necessário a execução das tarefas, tais como } \\
\text { chamadas telefônicas de longa distancia, viagens, } \\
\text { contratação de pessoal temporário para auxiliar no trabalho } \\
\text { e outros. }\end{array}$ & 3,11 & 1,15 & 8,1 & 21,6 & 35,1 & 21,6 & 13,5 \\
\hline $\begin{array}{l}\text { 39. Nesta organização, os recursos financeiros necessários } \\
\text { a realização das tarefas são liberados sempre a tempo de } \\
\text { terminar um trabalho dentro do prazo. }\end{array}$ & 3,14 & 0,68 & 2,7 & 5,4 & 67,6 & 18,9 & 5,4 \\
\hline $\begin{array}{l}\text { 1. Esta organização raramente fornece todos os recursos } \\
\text { materiais necessários ao bom desempenho das tarefas. }\end{array}$ & 3,46 & 1,43 & 25 & 30,6 & 16,7 & 13,9 & 13,9 \\
\hline 35 Esta organização e lenta demais na aquisição e na & 3,00 & 1,13 & 13,5 & 13,5 & 40,5 & 24,3 & 8,1 \\
\hline
\end{tabular}




\begin{tabular}{|c|c|c|c|c|c|c|c|}
\hline \multirow{2}{*}{ Item do Questionário } & \multirow{2}{*}{ Média } & \multirow{2}{*}{ DP } & \multicolumn{5}{|c|}{ \% Respostas } \\
\hline & & & 1 & 2 & 3 & 4 & 5 \\
\hline \multicolumn{8}{|l|}{$\begin{array}{l}\text { implementação do uso de equipamentos de segurança no } \\
\text { trabalho. }\end{array}$} \\
\hline $\begin{array}{l}\text { 51. Esta organização toma as providências necessárias para } \\
\text { sanar dificuldades ou remover obstáculos ao desempenho } \\
\text { eficaz. }\end{array}$ & 3,03 & 1,04 & 8,1 & 21,6 & 35,1 & 29,7 & 5,4 \\
\hline $\begin{array}{l}\text { 15. Esta organização preocupa-se em dinamizar e } \\
\text { modernizar constantemente os processos de trabalho. } \\
\text { 47. Esta organização investe na capacitação e }\end{array}$ & 2,92 & 1,32 & 16,2 & 27 & 18,9 & 24,3 & 13,5 \\
\hline $\begin{array}{l}\text { aprimoramento profissional dos seus funcionários, } \\
\text { oferecendo-lhes constantemente treinamentos específicos } \\
\text { segundo a área de atuação de cada um. }\end{array}$ & 2,86 & 1,27 & 18,9 & 18,9 & 29,7 & 21,6 & 10,8 \\
\hline $\begin{array}{l}\text { 43. Esta organização só se interessa pela produção } \\
\text { deixando de oferecer condições saudáveis de trabalho. }\end{array}$ & 3,49 & 1,28 & 29,7 & 21,6 & 21,6 & 21,6 & 5,4 \\
\hline Total & 3,31 & 0,36 & 9 & 20 & 26 & 25 & 20 \\
\hline
\end{tabular}

Fonte: Dados da pesquisa

Para o Grupo B da amostra, os dados descritos na tabela acima mostram que as médias situaram-se entre 4,05 e 2,35; dos 17 itens, apenas um item obteve média acima de 4; treze alcançaram médias entre 3,95 e 3,00; três ficaram com média abaixo de 3 (2,92 a 2,86); a concentração dos itens na afirmativa neutra foi de $26 \%$ do total das respostas. Os valores dos desvios padrão das questões ficaram entre 0,68 e 1,53. O escore médio dos itens desse fator situou-se em 3,31. Em relação ao desvio padrão das médias das questões, esse apresentou o valor de 0,36.

Dos 17 itens do fator, apenas um obteve mais de $60 \%$ das respostas concentradas nos escores de concordância, 5. Esta organização oferece locais de trabalho com móveis, equipamentos e materiais em quantidade suficiente, com média igual a 3,95 e desvio padrão de 1,15. Em relação aos escores de discordância, um item também concentrou mais de $60 \%$ das respostas nesses escores, 42. Aqui, apesar das reclamações dos funcionários, os locais de trabalho estão sempre sujos, com média 4,05 e desvio padrão de 1,05. Em ambos os casos, os itens relativos a suporte material foram avaliados positivamente pela maioria dos respondentes.

Como pode ser observado, diferentemente do Grupo A, a questão 5, foi bem avaliada pela amostra B. A explicação para essa divergência de opinião pode estar no local de trabalho de cada grupo, enquanto os servidores do Grupo B trabalham em locais fixos no órgão, possuindo móveis e equipamentos próprios e individuais de trabalho, os servidores do Grupo A, devido ao cargo ocupado, agentes de segurança, desempenham atividades externas, por isso, não dispõem de um local 
específico e fixo de trabalho, apenas possuem um ambiente coletivo para aqueles momentos em que não estão em atividade.

\subsubsection{Fator 4: Práticas organizacionais de ascensão, promoção e salários}

Nesta subseção serão descritos os resultados do quarto e último fator da escala de suporte, refere-se à opinião da amostra acerca das práticas organizacionais de retribuição financeira, promoções e ascensão funcionais sendo composto por 11 itens, sendo que os itens $3,8,9,21,25$ e 46 possuem carga fatorial negativa e tiveram seus sentidos invertidos para a criação do escore fatorial.

$\mathrm{Na}$ Tabela 9 podem ser vistas as médias, os desvios padrão e as freqüências relativas a cada escore do Grupo A da amostra.

Tabela 9: Fator 4 - Grupo A

\section{Item do Questionário}

\section{Média}

DP

1

46. As oportunidades de promoção e ascensão funcionais oferecidas por esta organização são compatíveis com as aspirações pessoais e profissionais dos funcionários.

17. Aqui, as oportunidades de promoção e ascensão funcionais são muito raras.

9. Aqui, os salários pagos aos funcionários são compatíveis com os melhores salários pagos no mercado para os mesmos tipos de ocupação ou cargos.

11. Esta organização oferece um final de carreira com salários muito baixos.

25. Nesta organização, há muitas maneiras pelas quais um funcionário pode ser promovido para cargos de melhor nível salarial (por exemplo, por meio de provas de conhecimento, por avaliação de merecimento, por conclusão de cursos, etc). 21. A organização esforça-se para manter os salários em patamares que permitam ao funcionário sentir menos o impacto da inflação.

3. A remuneração oferecida por esta organização permite que o funcionário desfrute a vida com dignidade.

8. Aqui, o funcionário exemplar tem maiores chances do que os outros de receber recompensas (como promoções, elogios certificados de merecimento e/ou similares).

44. Nesta organização, falta um plano de incentivos á escolarização mediante reclassificação salarial do funcionário que conclui, com êxito, cursos que excedam a escolaridade exigida para o cargo que ocupa.

48. As recompensas financeiras pagas ao funcionário a título de promoção têm valor baixo demais.

$\begin{array}{lcccccc}2,95 & 0,89 & 5 & 15 & 55 & 20 & 5 \\ 3,45 & 1,05 & & 20 & 35 & 25 & 20 \\ 2,55 & 1,54 & 20 & 5 & 20 & 20 & 35 \\ 2,80 & 1,06 & 5 & 40 & 35 & 10 & 10 \\ 3,40 & 1,19 & 25 & 15 & 40 & 15 & 5 \\ 2,90 & 1,29 & 10 & 30 & 15 & 30 & 15 \\ 2,20 & 1,24 & 5 & 15 & 10 & 35 & 35 \\ 3,35 & 1,23 & 20 & 30 & 20 & 25 & 5 \\ & & & & & & \\ 2,60 & 1,19 & 30 & 5 & 40 & 25 & \\ 2,95 & 1,36 & 20 & 15 & 30 & 20 & 15\end{array}$




\begin{tabular}{|c|c|c|c|c|c|c|c|}
\hline \multirow{2}{*}{ Item do Questionário } & \multirow{2}{*}{ Média } & \multirow{2}{*}{ DP } & \multicolumn{5}{|c|}{$\%$ Respostas } \\
\hline & & & 1 & 2 & 3 & 4 & 5 \\
\hline $\begin{array}{l}\text { 36. Esta organização deixa de oferecer cargos ou funções } \\
\text { importantes para o pessoal interno contratando pessoal } \\
\text { externo para assumi-los. }\end{array}$ & 2,60 & 0,94 & 20 & 10 & 60 & 10 & \\
\hline Total & 2,89 & 0,40 & 16 & 21 & 33 & 18 & 12 \\
\hline
\end{tabular}

Fonte: Dados da pesquisa

Os dados apresentados na tabela acima da amostra mostram que as médias dos itens situaram-se entre 3,45 e 2,20; dos 11 itens, três obtiveram médias acima de 3 $(3,45$ a 3,35) e oito alcançaram médias abaixo de 3 (2,95 a 2,20); a concentração dos itens na afirmativa neutra foi de $33 \%$ do total das respostas. O escore médio dos itens desse fator situou-se em 2,89. Os valores dos desvios padrão ficaram entre 0,89 e 1,54. Já o desvio padrão das médias dos itens, ficou em 0,40.

O item 3. A remuneração oferecida por esta organização permite que o funcionário desfrute a vida com dignidade, foi o único a concentrar mais de $60 \%$ das respostas nos escores de concordância. Já os itens 46. As oportunidades de promoção e ascensão funcionais oferecidas por esta organização são compatíveis com as aspirações pessoais e profissionais dos funcionários, com média igual a 2,95 e desvio padrão de 0,89; e o item 36. Esta organização deixa de oferecer cargos ou funções importantes para o pessoal interno contratando pessoal externo para assumi-los, com média 2,60 (DP 0,94), obtiveram mais de $50 \%$ das respostas concentradas no escore neutro. O que pode explicar essa concentração muito alta nesse escore é justamente a característica da amostra relativa à situação funcional do participante, verifica-se que $100 \%$ dos treinandos do Grupo A são servidores externos, ou seja, não pertencem ao quadro funcional da instituição e, portanto, não concorrem a promoção e ascensão profissional dentro da organização.

Os resultados relativos ao Grupo B da amostra são apresentados na Tabela 10.

Tabela 10: Fator 4 - Grupo B

\begin{tabular}{|c|c|c|c|c|c|c|c|}
\hline \multirow{2}{*}{ Item do Questionário } & \multirow{2}{*}{ Média } & \multirow{2}{*}{ DP } & \multicolumn{5}{|c|}{ \% Respostas } \\
\hline & & & 1 & 2 & 3 & 4 & 5 \\
\hline $\begin{array}{l}\text { 46. As oportunidades de promoção e ascensão funcionais } \\
\text { oferecidas por esta organização são compatíveis com as } \\
\text { aspirações pessoais e profissionais dos funcionários. }\end{array}$ & 3,62 & 1,04 & 24,3 & 29,7 & 29,7 & 16,2 & \\
\hline $\begin{array}{l}\text { 17. Aqui, as oportunidades de promoção e ascensão } \\
\text { funcionais são muito raras. }\end{array}$ & 3,49 & 1,28 & 8,1 & 16,2 & 21,6 & 27 & 27 \\
\hline 9. Aqui, os salários pagos aos funcionários são compatíveis & 3,03 & 1,34 & 16,2 & 24,3 & 21,6 & 21,6 & 16,2 \\
\hline
\end{tabular}




\begin{tabular}{|c|c|c|c|c|c|c|c|}
\hline \begin{tabular}{l}
\multicolumn{1}{c}{ Item do Questionário } \\
com os melhores salários pagos no mercado para os \\
mesmos tipos de ocupação ou cargos.
\end{tabular} & Média & DP & \multicolumn{5}{|c|}{ "\% Respostas } \\
\hline $\begin{array}{l}\text { 11. Esta organização oferece um final de carreira com } \\
\text { salários muito baixos. }\end{array}$ & 2,97 & 1,20 & 13,9 & 19,4 & 27,8 & 30,6 & \multirow[t]{2}{*}{8,3} \\
\hline $\begin{array}{l}\text { 25. Nesta organização, há muitas maneiras pelas quais um } \\
\text { funcionário pode ser promovido para cargos de melhor } \\
\text { nível salarial (por exemplo, por meio de provas de } \\
\text { conhecimento, por avaliação de merecimento, por } \\
\text { conclusão de cursos, etc). }\end{array}$ & 3,97 & 1,17 & 51,4 & 8,1 & 27 & 13,5 & \\
\hline $\begin{array}{l}\text { 21. A organização esforça-se para manter os salários em } \\
\text { patamares que permitam ao funcionário sentir menos o } \\
\text { impacto da inflação. }\end{array}$ & 3,54 & 1,17 & 29,7 & 16,2 & 35,1 & 16,2 & 2,7 \\
\hline $\begin{array}{l}\text { 3. A remuneração oferecida por esta organização permite } \\
\text { que o funcionário desfrute a vida com dignidade. }\end{array}$ & 2,14 & 1,18 & 5,4 & 8,1 & 18,9 & 29,7 & 37,8 \\
\hline $\begin{array}{l}\text { 8. Aqui, o funcionário exemplar tem maiores chances do } \\
\text { que os outros de receber recompensas (como promoções, } \\
\text { elogios certificados de merecimento e/ou similares). }\end{array}$ & 3,27 & 1,41 & 27 & 18,9 & 21,6 & 18,9 & 13,5 \\
\hline $\begin{array}{l}\text { 44. Nesta organização, falta um plano de incentivos á } \\
\text { escolarização mediante reclassificação salarial do } \\
\text { funcionário que conclui, com êxito, cursos que excedam a } \\
\text { escolaridade exigida para o cargo que ocupa. }\end{array}$ & 2,97 & 1,48 & 21,6 & 21,6 & 16,2 & 18,9 & 21,6 \\
\hline $\begin{array}{l}\text { 48. As recompensas financeiras pagas ao funcionário a } \\
\text { título de promoção têm valor baixo demais. }\end{array}$ & 3,11 & 0,94 & 8,1 & 8,1 & 54,1 & 24,3 & 5,4 \\
\hline $\begin{array}{l}\text { 36. Esta organização deixa de oferecer cargos ou funções } \\
\text { importantes para o pessoal interno contratando pessoal } \\
\text { externo para assumi-los. }\end{array}$ & 3,46 & 1,24 & 8,1 & 16,2 & 18,9 & 35,1 & 21,6 \\
\hline Total & 3,23 & 0,48 & 12 & 18 & 26 & 22 & 22 \\
\hline
\end{tabular}

Fonte: Dados da pesquisa

Em relação ao Grupo B da amostra as médias variaram de 3,62 a 2,14; oito itens alcançaram médias acima de 3 (3,62 a 3,03), dentre eles, estão os três primeiros itens mais importantes desse fator; quase $30 \%$ do total das respostas concentraramse na afirmativa neutra. Os valores dos desvios padrão se situaram entre 0,94 e 1,48. O valor obtido pelo cálculo do escore médio dos itens do fator ficou em 3,23 (DP 0,48).

De acordo com o conjunto de questões que compõem esse fator, os itens com melhores resultados foram: A melhor média, 3,97, foi alcançada pelo item 25 . Nesta organização, há muitas maneiras pelas quais um funcionário pode ser promovido para cargos de melhor nível salarial (por exemplo, por meio de provas de conhecimento, por avaliação de merecimento, por conclusão de cursos, etc), com média igual a $3,97(1,17)$, concentrando quase $60 \%$ das respostas nos escores de concordância; e o item 46. As oportunidades de promoção e ascensão funcionais oferecidas por esta organização são compatíveis com as aspirações pessoais e profissionais dos funcionários, com a segunda melhor média desse fator, 3,62 (DP 1,04). 
4.2.5 Resumo dos principais resultados da avaliação de suporte

Nesta subseção é exibido o resumo dos principais resultados das análises descritivas da avaliação da percepção de suporte organizacional.

O suporte organizacional, conforme descrito no referencial teórico, refere-se à opinião dos trabalhadores a cerca do comprometimento da organização para com eles e englobam as seguintes dimensões: práticas de desempenho, exigências e carga de trabalho, suporte material e práticas de promoção, ascensão e salários da organização.

As tabelas 11 e 12 apresentam as médias aritméticas gerais encontradas nos grupos A e B da amostra, respectivamente, para cada um dos fatores que compõem a escala de Percepção de Suporte Organizacional. As tabelas completas com os 52 itens do fator único encontram-se nos Apêndices B e C.

Tabela 11: Resumo dos resultados da avaliação de suporte - Grupo A

\begin{tabular}{|c|c|c|c|c|c|c|c|c|}
\hline \multirow{2}{*}{ Fator } & \multirow{2}{*}{ Média } & \multirow{2}{*}{ DP } & \multicolumn{6}{|c|}{ \% Respostas } \\
\hline & & & 1 & 2 & 3 & 4 & 5 & Total \\
\hline Fator 1: Gestão de desempenho & 3,22 & 0,49 & 13 & 17 & 24 & 30 & 16 & 100 \\
\hline Fator 2: Carga de trabalho & 2,23 & 0,45 & 48 & 13 & 17 & 13 & 9 & 100 \\
\hline Fator 3: Suporte Material & 3,33 & 0,62 & 14 & 14 & 20 & 28 & 24 & 100 \\
\hline $\begin{array}{l}\text { Fator 4: Práticas Organizacionais de } \\
\text { Ascensão, Promoção e Salários }\end{array}$ & 2,89 & 0,40 & 16 & 21 & 33 & 18 & 12 & 100 \\
\hline
\end{tabular}

Fonte: Dados da pesquisa

De acordo com os dados acima, as médias gerais dos fatores da escala de suporte do Grupo A variaram de 3,33 a 2,23. O desvio padrão relativo às médias de cada fator situaram-se entre 0,40 e 0,62, demonstrando que, dentro de cada fator, as médias dos itens não apresentaram grandes variações entre si.

É importante destacar os resultados do Fator 2 que avalia a percepção do empregado no que se refere à carga de trabalho da organização. Como pode ser observado, essa subescala concentrou mais de $60 \%$ do total das respostas nos escores de discordância, o que corrobora a média apresentada. No entanto, é importante lembrar que para os itens que compõem esse fator quanto maior a 
concentração das respostas nos escores 1 e 2, mais bem avaliado estará pelos respondentes.

O fator 3, relativo a opinião do trabalhador sobre o suporte material da organização, obteve a maior média, 3,33 (DP 0,62), pouco mais de $50 \%$ do total dos respondentes avaliaram positivamente o suporte da organização nessa dimensão.

No fator 4, referente a percepção do trabalhador sobre as práticas organizacionais de ascensão, promoção e salários, ocorreu grande concentração das respostas no escore neutro, $33 \%$.

A seguir, na Tabela 12 podem ser vistos o resumo dos resultados da amostra B.

Tabela 12: Resumo dos resultados da avaliação de suporte - Grupo B

\begin{tabular}{|c|c|c|c|c|c|c|c|c|}
\hline \multirow{2}{*}{ Fator } & \multirow{2}{*}{ Média } & \multirow{2}{*}{ DP } & \multicolumn{6}{|c|}{ \% Respostas } \\
\hline & & & 1 & 2 & 3 & 4 & 5 & Total \\
\hline Fator 1: Gestão de desempenho & 2,91 & 0,31 & 16 & 22 & 27 & 24 & 11 & 100 \\
\hline Fator 2: Carga de trabalho & 2,78 & 0,48 & 25 & 16 & 28 & 16 & 15 & 100 \\
\hline Fator 3: Suporte Material & 3,31 & 0,36 & 9 & 20 & 26 & 25 & 20 & 100 \\
\hline $\begin{array}{l}\text { Fator 4: Práticas Organizacionais de } \\
\text { Ascensão, Promoção e Salários }\end{array}$ & 3,23 & 0,48 & 12 & 18 & 26 & 22 & 22 & 100 \\
\hline
\end{tabular}

Em relação ao Grupo B, os resultados não foram muito diferentes dos observados no Grupo A. De acordo com os dados acima, verifica-se que as médias gerais variaram de 3,31 a 2,78 . O desvio padrão relativo às médias de cada fator situaramse entre 0,31 e 0,48 .

O Fator 2, carga de trabalho, não foi tão bem avaliado pelo Grupo B, em comparação com resultados obtidos na amostra $A$, a sua média geral foi igual a 2,78 (DP 0,48), com $41 \%$ das respostas concentradas nos escores de discordância e $28 \%$ no neutro.

Assim como no Grupo A, na amostra B a subescala relativa a suporte material apresentou média acima de 3 (3,31), com 45\% do total das respostas concentradas nos escores 4 e 5 . O fator 4, também apresentou resultados semelhantes a esse, a média ficou em 3,23 e o desvio padrão situou-se em 0,48. Em ambos os fatores verifica-se concentração de $26 \%$ do total das respostas no escore neutro. 
A partir dos resultados descritos acima, infere-se que a percepção dos dois grupos de empregados sobre as exigências e a carga de trabalho da organização indicando que as práticas adotadas pela organização, relativas a essa dimensão, estão próximos das expectativas da maioria desses servidores.

Por outro lado, os resultados das demais subescalas, tanto no Grupo A como no B, apontam para uma avaliação apenas razoável em relação às políticas adotadas pela organização no que concerne à gestão de desempenho, ao suporte material e às práticas de ascensão, promoção e salários.

Conforme apresentado na base teórica, Abbad, Freitas e Pilati (2006), afirmam que percepções desfavoráveis de suporte organizacional podem provocar problemas de desempenho não devidos à falta de CHAs no trabalho, mas à falta de condições favoráveis ao desempenho competente e/ou de motivação em decorrência de restrições situacionais no ambiente de trabalho.

Diante dos resultados encontrados, seria importante a organização dar uma atenção especial ao seu ambiente de trabalho com o intuito de identificar eventuais falhas que por ventura possam prejudicar o desempenho eficaz de seus funcionários, bem como investigar os seus principais motivos. Embora não seja possível para o TRF da 1ํㅡ Região generalizar os resultados encontrados, tendo em vista que a amostra foi pequena em relação ao total de seus servidores (aproximadamente 1200 servidores) e, além disso, correspondem à percepção de apenas duas categorias bastante específicas do órgão, agentes de segurança e servidores das turmas.

\subsection{Relações entre as variáveis em estudo}

Nesta seção são apresentados os resultados das análises correlacionais efetuadas entre as variáveis da pesquisa, objetivo geral desse estudo.

As correlações de Pearson foram realizadas entre as variáveis formadas pelas médias de cada um dos itens que compõem cada um dos quatro fatores da escala de Percepção de Suporte Organizacional e pela escala única de auto-avaliação de impacto em amplitude. 
Os resultados encontrados, relativos aos dois grupos da amostra, são apresentados na Tabela 13.

Tabela 13: Correlações entre os fatores de suporte e a medida de impacto

VARIÁVEL

Fator 1: Gestão de desempenho

Fator 2: Carga de trabalho

Fator 3: Suporte Material

Fator 4: Práticas Organizacionais de Ascensão, Promoção e Salários

${ }^{*} \mathrm{p}<0,05$

Fonte: Dados da pesquisa

\section{Impacto em Amplitude}

Grupo A

0,257

$-0,158$

0,137

$-0,219$
0,193

$-0,355^{*}$

0,297

Grupo B

$-0,215$

Pode-se observar na tabela 13, uma correlação negativa significativa $(p<0,05)$ de nível moderado, no Grupo $\mathrm{B}$ da amostra, entre o fator 2 relativo à carga de trabalho da escala de suporte e a variável de impacto do treinamento no trabalho em amplitude. Isso significa dizer que essas variáveis movem-se em direções opostos, existindo uma relação inversa entre elas, ou seja, quando uma aumenta a outra diminui e vice-versa.

A partir dos resultados das correlações apresentados na tabela acima, verifica-se que não foram encontradas correlações significativas entre o impacto do treinamento no trabalho e as demais subescalas de suporte organizacional.

Esta pesquisa não apresentou os mesmos resultados obtidos por Lima, BorgesAndrade e Vieira (1989), pioneiros na investigação do relacionamento entre condições ambientais e impacto. Em seus estudos encontraram predominância das condições de trabalho e de vida na organização na explicação do impacto dos cursos no desempenho. Assim como esses autores, Abbad, Pilati e Pantoja (2003), em revisão de literatura, também encontraram como as mais fortes preditoras do impacto do treinamento no trabalho as variáveis de suporte organizacional nas subescalas de gestão de desempenho e valorização do servidor. 


\section{CONCLUSÕES E RECOMENDAÇÕES}

O objetivo geral proposto por este estudo foi relacionar as variáveis percepção de suporte organizacional e impacto do treinamento no trabalho, através da autoavaliação de dois cursos oferecidos pelo TRF da 1ํㅡ Região a seus servidores e da análise da percepção de suporte organizacional desses treinandos.

O tipo de pesquisa utilizado foi de natureza quantitativa. Quanto aos fins pode ser considerada descritiva e explicativa e, em relação aos meios, de campo. A amostra foi composta por dois grupos, a saber: Grupo A, 20 servidores que realizaram 0 curso técnicas de segurança para autoridades; e Grupo B, 37 servidores participantes do curso sistemas GPD e G-DOC. Foram utilizados dois instrumentos de pesquisa cientificamente validados, a escala de Impacto do Treinamento no Trabalho (IMPACT) e a escala de Percepção de Suporte Organizacional. Os dados foram analisados com o auxílio de dois aplicativos o Microsoft Excel (Office 2007) e - Statistical Package for the Social Sciences (SPSS) 18.0. Através desses programas, foram calculadas medidas descritivas (média, desvios padrão e freqüência) e correlações de Pearson entre as variáveis do estudo.

Os resultados da auto-avaliação do impacto do treinamento no trabalho foram positivos para ambos os grupos, havendo impacto maior para o Grupo A, treinandos do curso técnicas de segurança para autoridades. A diferença entre os grupos pode estar relacionada às especificidades de cada evento instrucional, enquanto o curso do Grupo A tinha relação direta com as atividades desempenhadas pelos treinandos, com o do Grupo B, os cursos restringiram-se a dois programas que fazem parte das suas atividade, além disso, esses treinandos já possuíam certo conhecimento desses sistemas.

Em relação à percepção de suporte organizacional, os resultados foram apresentados segundo os quatro fatores que compõem a escala de Percepção de Suporte Organizacional utilizada: fator 1: gestão de desempenho; fator 2: carga de trabalho; fator 3: suporte material; e fator 4: práticas organizacionais de ascensão, promoção e salários. O fator mais bem avaliado para os dois grupos correspondeu à carga de trabalho da organização, indicando que as práticas adotadas pela 
organização, relativas a essa dimensão, estão próximos das expectativas da maioria desses funcionários.

As demais subescalas, para ambos os treinandos, indicaram uma avaliação apenas razoável em relação às políticas adotadas pela organização relativas à gestão de desempenho, ao suporte material e às práticas de ascensão, promoção e salários.

No que se refere ao objetivo geral, relacionar a percepção de suporte organizacional e o impacto dos cursos, foi encontrada correlação negativa moderada entre a subescala relativa à carga de trabalho e a variável impacto do treinamento no trabalho, na amostra do Grupo B. Em relação aos demais fatores, não foram encontradas correlações significativas, divergindo dos estudos realizados por Lima, Borges-Andrade e Vieira (1989) e Abbad, Pilati e Pantoja (2003).

A primeira limitação deste trabalho refere-se ao tamanho da amostra que correspondeu, apenas, a aproximadamente 5\% dos servidores do órgão. Essa limitação compromete a possibilidade de que os resultados relativos à percepção de suporte organizacional sejam generalizados tanto dentro da própria organização, como para outros contextos e organizações.

A segunda limitação relaciona-se à escala de suporte organizacional, por ter os enunciados de cada item bastante longos, somado ao número de itens (52), pode produzir nos respondentes certa impaciência e fazer com eles avaliem cada questão de maneira displicente. Além disso, em sua validação, dentre os 166 trabalhadores que participaram desse processo, apenas 31 eram de órgãos públicos, os demais se dividiam em 22 de empresas públicas e 60 de empresas privadas. Talvez os itens que compõem essa escala não consigam captar a opinião dessa categoria específica de forma a conseguir avaliar o suporte organizacional de maneira mais precisa. A grande concentração de respostas no escore neutro observada nessa escala pode ser um indicio que confirma essas duas possibilidades.

A terceira limitação se refere a um possível viés introduzido pela entrega dos questionários aos participantes da pesquisa pelos seus superiores. Esse procedimento pode provocar algum tipo de constrangimento nos respondentes, apesar do compromisso de sigilo assumido pela pesquisadora.

Os resultados desse estudo podem contribuir para a organização pesquisada ter conhecimento sobre o impacto no desempenho dos cursos avaliados, bem como, 
para ter alguma idéia da opinião dos seus funcionários a respeitos das praticas que adota nas dimensões de gestão de desempenho, carga de trabalho, suporte material e valorização do trabalhador.

Para a academia, este trabalho serviu para confirmar a necessidade de que se façam mais pesquisas relacionando as variáveis de impacto do treinamento no trabalho e percepção de suporte organizacional. 


\section{REFERÊNCIAS}

ABBAD, Gardênia. (1999). Um modelo integrado de impacto de treinamento no trabalho - IMPACT. Tese de Doutorado. Universidade de Brasília.

ABBAD, Gardênia; PILATI, Ronaldo; PANTOJA, Maria J. Avaliação de treinamento: análise da literatura e agenda de pesquisa. Revista de Administração, São Paulo, v. 38, n. 3, p. 205-218, jul./ago./set. 2003.

ABBAD, Gardênia da Silva; FREITAS, Isa Aparecida de; PILATI, Ronaldo. Contexto de trabalho, desempenho competente e necessidades em TD\&E. In: BORGESANDRADE, Jairo E.; ABBAD, Gardênia da Silva; MOURÃO, Luciana.

(Organizadores). Treinamento, desenvolvimento e educação em organizações e trabalho: fundamentos para a gestão de pessoas. Porto Alegre: Artmed, 2006. p. 231-254.

ABBAD, Gardênia; SALLORENZO, Lucia Henriques. Desenvolvimento e validação de escalas de suporte à transferência de treinamento. Revista de Administração, São Paulo, v. 36, n. 2, p. 33-45, abr./jun. 2001.

ABBAD, Gardênia da Silva. et al. Medidas de suporte em avaliação de TD\&E. In: BORGES-ANDRADE, Jairo E.; ABBAD, Gardênia da Silva; MOURÃO, Luciana. (Organizadores). Treinamento, desenvolvimento e educação em organizações e trabalho: fundamentos para a gestão de pessoas. Porto Alegre: Artmed, 2006. p. 395-421.

BASTOS, Antônio V. B. O suporte oferecido pela pesquisa na área de treinamento. Revista de Administração, São Paulo, v. 26, n. 4, p. 87-102, out./dez. 1991.

BASTOS, Antônio V. B. Trabalho e qualificação: questões conceituais e desafios postos pelo cenário de reestruturação produtiva. In: BORGES-ANDRADE, Jairo E.; ABBAD, Gardênia da Silva; MOURÃO, Luciana. (Organizadores). Treinamento, desenvolvimento e educação em organizações e trabalho: fundamentos para a gestão de pessoas. Porto Alegre: Artmed, 2006. p. 23-40.

BORGES-ANDRADE, Jairo E. Desenvolvimento de medidas em avaliação de treinamento. Estudos de Psicologia, Natal, RN, v. 7, n. Especial, p. 31-43, 2002.

. Avaliação integrada e somativa em TD\&E. In: BORGES-ANDRADE, Jairo E.; ABBAD, Gardênia da Silva; MOURÃO, Luciana. (Organizadores). Treinamento, 
desenvolvimento e educação em organizações e trabalho: fundamentos para a gestão de pessoas. Porto Alegre: Artmed, 2006a. p. 343-358.

Competência técnica e política do profissional de TD\&E. In: BORGES-

ANDRADE, Jairo E.; ABBAD, Gardênia da Silva; MOURÃO, Luciana.

(Organizadores). Treinamento, desenvolvimento e educação em organizações e trabalho: fundamentos para a gestão de pessoas. Porto Alegre: Artmed, 2006b. p. 177-195.

BRASIL. Governo Federal. Constituição da República Federativa do Brasil: promulgada em 5 de outubro de 1988. Disponível em: <http://www.planalto.gov.br/ccivil_03/Constituicao/Constitui\%C3\%A7ao.htm>. Acesso em 09/05/2010.

CARVALHO, Renata S.; ABBAD, Gardênia. Avaliação de treinamento à distância: reação, suporte à transferência e impactos no trabalho. RAC, Curitiba, v. 10, n. 001, jan./mar. 2006.

FREITAS, Isa Aparecida de. et al. Medidas de impacto de TD\&E no trabalho e nas organizações. In: BORGES-ANDRADE, Jairo E.; ABBAD, Gardênia da Silva; MOURÃO, Luciana. (Organizadores). Treinamento, desenvolvimento e educação em organizações e trabalho: fundamentos para a gestão de pessoas. Porto Alegre: Artmed, 2006. p. 489-504.

GONDIM, Sônia M. G. et al. Práticas inovadoras em gestão de produção e de pessoas e TD\&E. In: BORGES-ANDRADE, Jairo E.; ABBAD, Gardênia da Silva; MOURÃO, Luciana. (Organizadores). Treinamento, desenvolvimento e educação em organizações e trabalho: fundamentos para a gestão de pessoas. Porto Alegre: Artmed, 2006. p. 65-84.

HAMBLIM, Anthony Crandell. Avaliação e controle do treinamento. Tradução Gert Meyer. São Paulo: McGraw-Hill do Brasil, 1978.

LACERDA, Érika R. M.; ABBAD, Gardênia. Impacto do treinamento no trabalho: investigando variáveis motivacionais e organizacionais como suas preditoras. RAC, v. 7, n. 4, p. 77-96, out./dez. 2003.

LACOMBE, Francisco J. M. Dicionário de administração. São Paulo: Saraiva, 2004.

LIMA, Suzana M. V.; BORGES-ANDRADE, Jairo E.; VIEIRA, Solange B. A. Cursos de curta duração e desempenho em instituições de pesquisa agrícola. Revista de Administração, v. 24, n. 2, p. 36-46, abr./jun. 1989. 
MATIAS-PEREIRA, José. Metodologia científica: manual de pesquisa científica. Brasília: ADM/EAD, 2006.

MEISTER, Jeanne C. Educação Corporativa. Tradução Maria Cláudia Santos Ribeiro Ratto. São Paulo: Pearson Makron Books, 1999.

OLIVEIRA-CASTRO, Gardênia Abbad de; PILATI, Ronaldo; BORGES-ANDRADE, Jairo Eduardo. Percepção de suporte organizacional: desenvolvimento e validação de um questionário. RAC, v. 3, n. 2, p. 29-51, mai./ago. 1999.

PANTOJA, Maria J.; LIMA, Suzana M. V.; BORGES-ANDRADE, Jairo E. Avaliação de impacto de treinamento na área de reabilitação: preditores individuais $e$ situacionais. Revista de Administração, São Paulo, v. 36, n. 2, p. 46-56, abr./jun. 2001.

PANTOJA, Maria J. et al. Valores, suporte psicossocial e impacto do treinamento no trabalho. Estudos de Psicologia, São Paulo, 10(2), p. 255-265. 2005.

PASCHOAL, Tatiane; TORRES, Cláudio V.; PORTO, Juliana B. Felicidade no Trabalho: relações com suporte organizacional e suporte social. RAC, v. 14, n. 6, p. 1054-1072, nov./dez. 2010.

PILATI, Ronaldo. História e importância de TD\&E. In: BORGES-ANDRADE, Jairo E.; ABBAD, Gardênia da Silva; MOURÃO, Luciana. (Organizadores). Treinamento, desenvolvimento e educação em organizações e trabalho: fundamentos para a gestão de pessoas. Porto Alegre: Artmed, 2006. p. 159-176.

PILATI, Ronaldo; ABBAD, Gardênia. Análise fatorial confirmatória da escala de impacto do treinamento no trabalho. Psicologia: Teoria e Pesquisa, Brasília, v. 21, n. 1, p. 43-51, jan./abr. 2005.

SALLORENZO, Lúcia $H$. Avaliação de impacto de treinamento no trabalho: analisando e comparando modelos de predição. 2000. Dissertação (Mestrado) Instituto de Psicologia da Universidade de Brasília, Brasília, Distrito Federal, Brasil.

VARGAS, Miramar R. M. Treinamento e desenvolvimento: reflexões sobre sues métodos. Revista de Administração, São Paulo, v. 31, n. 2, p. 126-136, abr./jun. 1996.

VARGAS, Miramar R. M.; ABBAD; Gardênia da S. Bases conceituais em treinamento, desenvolvimente e educação - TD\&E. In: BORGES-ANDRADE, Jairo E.; ABBAD, Gardênia da Silva; MOURẢ̉, Luciana. (Organizadores). Treinamento, 
desenvolvimento e educação em organizações e trabalho: fundamentos para a gestão de pessoas. Porto Alegre: Artmed, 2006. p. 137-158.

VERGARA, Sylvia Constant. Projetos e relatórios de pesquisa em administração. 11 ed. São Paulo: Atlas, 2009.

ZANELLA, L. C. H. Metodologia da pesquisa. Florianópolis: SeaD/UFSC, 2006. 


\section{APÊNDICES}


Apêndice A - Questionário Perfil do Participante da Pesquisa

\section{Dados Pessoais}

Sexo:

( ) Masculino ( ) Feminino

\section{Faixa Etária:}
( ) até 20 anos
( ) de 21 a 30 anos
( ) de 31 a 40 anos
( ) de 41 a 50 ano
( ) de 51 a 60 anos
( ) de 61 a 70 anos

\section{Nível de instrução:}
( ) 1ํo grau completo
( ) especialização
( ) $2^{\circ}$ grau completo
( ) mestrado
( ) superior incompleto
( ) outros. Especifique:
( ) superior completo

\section{Situação Funcional:}

( ) Servidor do Quadro ( ) Servidor Requisitado ( ) Servidor sem Vínculo

Tempo de serviço no órgão:
( ) até 2 anos
( ) de 3 a 5 anos
( ) de 6 a 10 anos
( ) de 11 a 15 anos
( ) mais de 15 anos 


\section{Apêndice B - Resultados Descritivos da Avaliação de Suporte Organizacional - Técnicas de Segurança para Autoridades}

\begin{tabular}{|c|c|c|c|c|c|c|c|}
\hline \multirow{2}{*}{ Item do Questionário } & \multirow{2}{*}{ Média } & \multirow{2}{*}{$\mathbf{D P}$} & \multicolumn{5}{|c|}{ \% Respostas } \\
\hline & & & 1 & 2 & 3 & 4 & 5 \\
\hline $\begin{array}{l}\text { 1. Esta organização raramente fornece todos os recursos } \\
\text { materiais necessários ao bom desempenho das tarefas. }\end{array}$ & 2,85 & 1,14 & 5 & 35 & 5 & 50 & 5 \\
\hline $\begin{array}{l}\text { 2. Nesta organização, são pouco freqüentes as } \\
\text { manifestações de reconhecimento pelo trabalho bem } \\
\text { feito. }\end{array}$ & 3,10 & 0,30 & 20 & 5 & 25 & 45 & 5 \\
\hline $\begin{array}{l}\text { 3. A remuneração oferecida por esta organização permite } \\
\text { que o funcionário desfrute a vida com dignidade. }\end{array}$ & 2,20 & 1,24 & 5 & 15 & 10 & 35 & 35 \\
\hline $\begin{array}{l}\text { 4. Aqui, o funcionário sabe exatamente o que deve fazer } \\
\text { e quais são as metas de desempenho esperadas. }\end{array}$ & 4,40 & 0,75 & & 5 & & 45 & 50 \\
\hline $\begin{array}{l}\text { 5. Esta organização oferece locais de trabalho com } \\
\text { móveis, equipamentos e materiais em quantidade } \\
\text { suficiente. }\end{array}$ & 2,40 & 1,19 & 30 & 20 & 35 & 10 & 5 \\
\hline $\begin{array}{l}\text { 6. Esta organização valoriza novas idéias e propostas } \\
\text { criativas de trabalho feitas pelos funcionários. }\end{array}$ & 3,10 & 1,29 & 15 & 20 & 15 & 40 & 10 \\
\hline $\begin{array}{l}\text { 7. Esta organização, ao julgar o desempenho do } \\
\text { funcionário, leva em conta o esforço que ele despendeu } \\
\text { para atingir os resultados esperados. }\end{array}$ & 3,40 & 1,27 & 15 & 5 & 20 & 45 & 15 \\
\hline $\begin{array}{l}\text { 8. Aqui, o funcionário exemplar tem maiores chances do } \\
\text { que os outros de receber recompensas (como promoções, } \\
\text { elogios certificados de merecimento e/ou similares). }\end{array}$ & 3,35 & 1,23 & 20 & 30 & 20 & 25 & 5 \\
\hline $\begin{array}{l}\text { 9. Aqui, os salários pagos aos funcionários são } \\
\text { compatíveis com os melhores salários pagos no mercado } \\
\text { para os mesmos tipos de ocupação ou cargos. }\end{array}$ & 2,55 & 1,54 & 20 & 5 & 20 & 20 & 35 \\
\hline $\begin{array}{l}\text { 10. Esta organização desconsidera as sugestões de } \\
\text { mudança e modernização de procedimentos de trabalho } \\
\text { feitas até mesmo pelo funcionário mais experiente. }\end{array}$ & 2,74 & 0,30 & 15 & 25 & 40 & 20 & \\
\hline $\begin{array}{l}\text { 11. Esta organização oferece um final de carreira com } \\
\text { salários muito baixos. }\end{array}$ & 2,80 & 1,06 & 5 & 40 & 35 & 10 & 10 \\
\hline $\begin{array}{l}\text { 12. Esta organização procura melhorar constantemente as } \\
\text { condições físicas dos locais de trabalho. }\end{array}$ & 2,60 & 1,23 & 20 & 30 & 30 & 10 & 10 \\
\hline $\begin{array}{l}\text { 13. Esta organização possui um espaço para tomar } \\
\text { conhecimento dos problemas pessoais dos funcionários e } \\
\text { prestar-lhes orientação e aconselhamento. }\end{array}$ & 3,10 & 1,15 & 30 & 10 & 5 & 30 & 25 \\
\hline $\begin{array}{l}\text { 14. Esta organização desconsidera os interesses pessoais } \\
\text { do funcionário, ao tomar decisões administrativas (como } \\
\text { transferências, por exemplo) relativas a ele. }\end{array}$ & 2,90 & 1,07 & 10 & 25 & 35 & 25 & 5 \\
\hline $\begin{array}{l}\text { 15. Esta organização preocupa-se em dinamizar e } \\
\text { modernizar constantemente os processos de trabalho. }\end{array}$ & 3,25 & 1,21 & 5 & 30 & 15 & 35 & 15 \\
\hline $\begin{array}{l}\text { 16. Esta organização prefere contratar pessoal externo } \\
\text { para lidar com máquinas ou equipamentos recém } \\
\text { adquiridos, do que investir em treinamento dos seus } \\
\text { funcionários para manuseá-las. }\end{array}$ & 3,00 & 1,15 & 20 & 15 & 20 & 35 & 10 \\
\hline $\begin{array}{l}\text { 17. Aqui, as oportunidades de promoção e ascensão } \\
\text { funcionais são muito raras. }\end{array}$ & 3,45 & 1,05 & & 20 & 35 & 25 & 20 \\
\hline $\begin{array}{l}\text { 18. Esta organização preocupa-se em proporcionar o } \\
\text { desenvolvimento das capacidades do funcionário, } \\
\text { oferecendo-lhe tarefas desafiadoras. }\end{array}$ & 2,80 & 1,32 & 25 & 15 & 20 & 35 & 5 \\
\hline $\begin{array}{l}\text { 19. Esta organização cumpre as promessas que faz aos } \\
\text { funcionários. }\end{array}$ & 3,65 & 1,51 & 5 & 10 & 20 & 45 & 20 \\
\hline $\begin{array}{l}\text { 20. Esta organização procura conhecer as dificuldades } \\
\text { encontradas pelo funcionário no desempenho de suas } \\
\text { atividades. }\end{array}$ & 2,95 & 1,43 & 25 & 10 & 25 & 25 & 15 \\
\hline $\begin{array}{l}\text { 21. A organização esforça-se para manter os salários em } \\
\text { patamares que permitam ao funcionário sentir menos o } \\
\text { impacto da inflação. }\end{array}$ & 2,90 & 1,29 & 10 & 30 & 15 & 30 & 15 \\
\hline $\begin{array}{l}\text { 22. Esta organização oferece todo o suporte financeiro } \\
\text { extra necessário a execução das tarefas, tais como } \\
\text { chamadas telefônicas de longa distancia, viagens, } \\
\text { contratação de pessoal temporário para auxiliar no }\end{array}$ & 2,35 & 1,53 & 45 & 15 & 15 & 10 & 15 \\
\hline
\end{tabular}




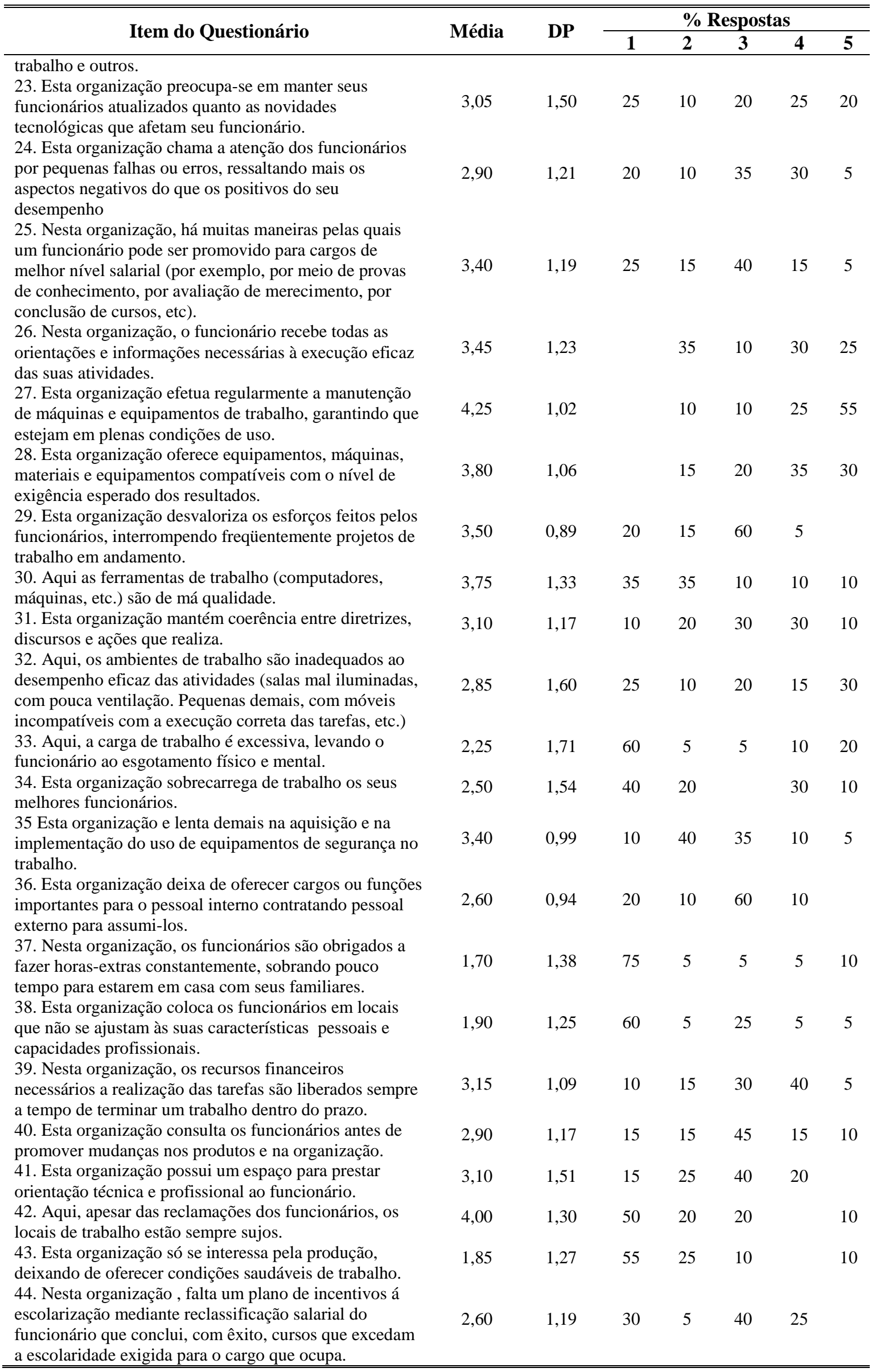




\begin{tabular}{|c|c|c|c|c|c|c|c|}
\hline \multirow{2}{*}{ Item do Questionário } & \multirow{2}{*}{ Média } & \multirow{2}{*}{$\mathbf{D P}$} & \multicolumn{5}{|c|}{ \% Respostas } \\
\hline & & & 1 & 2 & 3 & 4 & 5 \\
\hline $\begin{array}{l}\text { 45. Esta organização suga a energia do funcionário, } \\
\text { obrigando-o a trabalhar um número excessivo de horas, } \\
\text { sem pagar horas-extras ou aumentar o número de } \\
\text { funcionários. }\end{array}$ & 2,05 & 1,61 & 65 & 5 & 5 & 10 & 15 \\
\hline $\begin{array}{l}\text { 46. As oportunidades de promoção e ascensão funcionais } \\
\text { oferecidas por esta organização são compatíveis com as } \\
\text { aspirações pessoais e profissionais dos funcionários. }\end{array}$ & 2,95 & 0,89 & 5 & 15 & 55 & 20 & 5 \\
\hline $\begin{array}{l}\text { 47. Esta organização investe na capacitação e } \\
\text { aprimoramento profissional dos seus funcionários, } \\
\text { oferecendo-lhes constantemente treinamentos específicos } \\
\text { segundo a área de atuação de cada um. }\end{array}$ & 4,15 & 0,81 & & 5 & 10 & 50 & 35 \\
\hline $\begin{array}{l}\text { 48. As recompensas financeiras pagas ao funcionário a } \\
\text { título de promoção têm valor baixo demais. }\end{array}$ & 2,95 & 1,36 & 20 & 15 & 30 & 20 & 15 \\
\hline $\begin{array}{l}\text { 49. Aqui, o funcionário pode opinar decisivamente na } \\
\text { resolução de problemas de trabalho. }\end{array}$ & 2,35 & 1,14 & 30 & 25 & 25 & 20 & \\
\hline $\begin{array}{l}\text { 50. Esta organização determina prazos irrealistas para a } \\
\text { entrega de trabalhos, sem se preocupar se estão } \\
\text { disponíveis os recursos financeiros, materiais e humanos } \\
\text { necessários a sua execução. }\end{array}$ & 2,00 & 1,12 & 45 & 20 & 30 & & 5 \\
\hline $\begin{array}{l}\text { 51. Esta organização toma as providências necessárias } \\
\text { para sanar dificuldades ou remover obstáculos ao } \\
\text { desempenho eficaz. }\end{array}$ & 3,55 & 1,00 & 5 & 5 & 35 & 40 & 15 \\
\hline $\begin{array}{l}\text { 52. Esta organização esforça-se para adquirir } \\
\text { equipamentos modernos de trabalho que agilizam a } \\
\text { execução das tarefas. }\end{array}$ & 3,05 & 1,43 & 25 & 5 & 25 & 30 & 15 \\
\hline
\end{tabular}




\section{Apêndice C - Resultados Descritivos da Avaliação de Suporte Organizacional - Sistemas GPD e G-DOC}

\begin{tabular}{|c|c|c|c|c|c|c|c|}
\hline \multirow{2}{*}{ Item do Questionário } & \multirow{2}{*}{ Média } & \multirow{2}{*}{$\mathbf{D P}$} & \multicolumn{5}{|c|}{ \% Respostas } \\
\hline & & & 1 & 2 & 3 & 4 & 5 \\
\hline $\begin{array}{l}\text { 1. Esta organização raramente fornece todos os recursos } \\
\text { materiais necessários ao bom desempenho das tarefas. }\end{array}$ & 3,46 & 1,43 & 25 & 30,6 & 16,7 & 13,9 & 13,9 \\
\hline $\begin{array}{l}\text { 2. Nesta organização, são pouco frequientes as } \\
\text { manifestações de reconhecimento pelo trabalho bem } \\
\text { feito. }\end{array}$ & 3,27 & 1,45 & 13,5 & 21,6 & 18,9 & 16,2 & 29,7 \\
\hline $\begin{array}{l}\text { 3. A remuneração oferecida por esta organização permite } \\
\text { que o funcionário desfrute a vida com dignidade. }\end{array}$ & 2,14 & 1,18 & 5,4 & 8,1 & 18,9 & 29,7 & 37,8 \\
\hline $\begin{array}{l}\text { 4. Aqui, o funcionário sabe exatamente o que deve fazer } \\
\text { e quais são as metas de desempenho esperadas. }\end{array}$ & 3,57 & 1,34 & 8,1 & 18,9 & 13,5 & 27 & 32,4 \\
\hline $\begin{array}{l}\text { 5. Esta organização oferece locais de trabalho com } \\
\text { móveis, equipamentos e materiais em quantidade } \\
\text { suficiente. }\end{array}$ & 3,95 & 1,15 & 5,4 & 8,1 & 10,8 & 37,8 & 37,8 \\
\hline $\begin{array}{l}\text { 6. Esta organização valoriza novas idéias e propostas } \\
\text { criativas de trabalho feitas pelos funcionários. }\end{array}$ & 3,03 & 1,30 & 13,5 & 24,3 & 24,3 & 21,6 & 16,2 \\
\hline $\begin{array}{l}\text { 7. Esta organização, ao julgar o desempenho do } \\
\text { funcionário, leva em conta o esforço que ele despendeu } \\
\text { para atingir os resultados esperados. }\end{array}$ & 3,00 & 1,25 & 16,2 & 18,9 & 21,6 & 35,1 & 8,1 \\
\hline $\begin{array}{l}\text { 8. Aqui, o funcionário exemplar tem maiores chances do } \\
\text { que os outros de receber recompensas (como promoções, } \\
\text { elogios certificados de merecimento e/ou similares). }\end{array}$ & 3,27 & 1,41 & 27 & 18,9 & 21,6 & 18,9 & 13,5 \\
\hline $\begin{array}{l}\text { 9. Aqui, os salários pagos aos funcionários são } \\
\text { compatíveis com os melhores salários pagos no mercado } \\
\text { para os mesmos tipos de ocupação ou cargos. }\end{array}$ & 3,03 & 1,34 & 16,2 & 24,3 & 21,6 & 21,6 & 16,2 \\
\hline $\begin{array}{l}\text { 10. Esta organização desconsidera as sugestões de } \\
\text { mudança e modernização de procedimentos de trabalho } \\
\text { feitas até mesmo pelo funcionário mais experiente. }\end{array}$ & 2,84 & 1,19 & 16,2 & 21,6 & 32,4 & 21,6 & 8,1 \\
\hline $\begin{array}{l}\text { 11. Esta organização oferece um final de carreira com } \\
\text { salários muito baixos. }\end{array}$ & 2,97 & 1,20 & 13,9 & 19,4 & 27,8 & 30,6 & 8,3 \\
\hline $\begin{array}{l}\text { 12. Esta organização procura melhorar constantemente as } \\
\text { condições físicas dos locais de trabalho. }\end{array}$ & 3,22 & 1,06 & 2,7 & 27 & 27 & 32,4 & 10,8 \\
\hline $\begin{array}{l}\text { 13. Esta organização possui um espaço para tomar } \\
\text { conhecimento dos problemas pessoais dos funcionários e } \\
\text { prestar-lhes orientação e aconselhamento. }\end{array}$ & 2,51 & 1,37 & 35,1 & 13,5 & 24,3 & 18,9 & 8,1 \\
\hline $\begin{array}{l}\text { 14. Esta organização desconsidera os interesses pessoais } \\
\text { do funcionário, ao tomar decisões administrativas (como } \\
\text { transferências, por exemplo) relativas a ele. }\end{array}$ & 2,84 & 1,01 & 10,8 & 18,9 & 54,1 & 8,1 & 8,1 \\
\hline $\begin{array}{l}\text { 15. Esta organização preocupa-se em dinamizar e } \\
\text { modernizar constantemente os processos de trabalho. } \\
\text { 16. Esta organizacão prefere contratar pessoal externo }\end{array}$ & 2,92 & 1,32 & 16,2 & 27 & 18,9 & 24,3 & 13,5 \\
\hline $\begin{array}{l}\text { para lidar com máquinas ou equipamentos recém } \\
\text { adquiridos, do que investir em treinamento dos seus } \\
\text { funcionários para manuseá-las. }\end{array}$ & 3,30 & 1,24 & 13,5 & 5,4 & 37,8 & 24,3 & 18,9 \\
\hline $\begin{array}{l}\text { 17. Aqui, as oportunidades de promoção e ascensão } \\
\text { funcionais são muito raras. }\end{array}$ & 3,49 & 1,28 & 8,1 & 16,2 & 21,6 & 27 & 27 \\
\hline $\begin{array}{l}\text { 18. Esta organização preocupa-se em proporcionar o } \\
\text { desenvolvimento das capacidades do funcionário, } \\
\text { oferecendo-lhe tarefas desafiadoras. }\end{array}$ & 2,62 & 1,11 & 18,9 & 27 & 29,7 & 21,6 & 2,7 \\
\hline $\begin{array}{l}\text { 19. Esta organização cumpre as promessas que faz aos } \\
\text { funcionários. }\end{array}$ & 2,86 & 0,92 & 8,1 & 18,9 & 56,8 & 10,8 & 5,4 \\
\hline $\begin{array}{l}\text { 20. Esta organização procura conhecer as dificuldades } \\
\text { encontradas pelo funcionário no desempenho de suas } \\
\text { atividades. }\end{array}$ & 2,92 & 1,26 & 18,9 & 16,2 & 27 & 29,7 & 8,1 \\
\hline $\begin{array}{l}\text { 21. A organização esforça-se para manter os salários em } \\
\text { patamares que permitam ao funcionário sentir menos o } \\
\text { impacto da inflação. }\end{array}$ & 3,54 & 1,17 & 29,7 & 16,2 & 35,1 & 16,2 & 2,7 \\
\hline $\begin{array}{l}\text { 22. Esta organização oferece todo o suporte financeiro } \\
\text { extra necessário a execução das tarefas, tais como } \\
\text { chamadas telefônicas de longa distancia, viagens, } \\
\text { contratação de pessoal temporário para auxiliar no }\end{array}$ & 3,11 & 1,15 & 8,1 & 21,6 & 35,1 & 21,6 & 13,5 \\
\hline
\end{tabular}




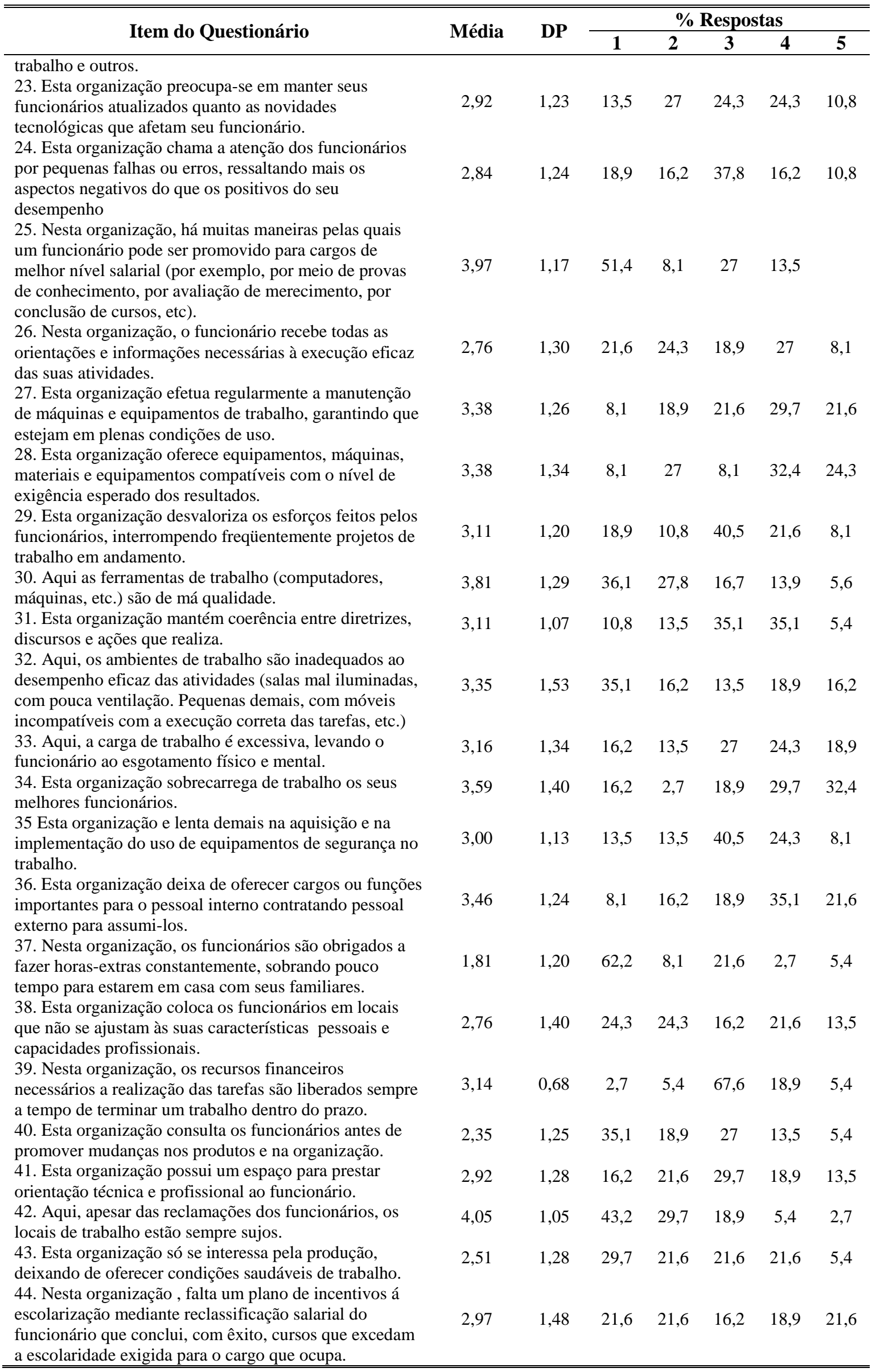




\begin{tabular}{|c|c|c|c|c|c|c|c|}
\hline \multirow{2}{*}{ Item do Questionário } & \multirow{2}{*}{ Média } & \multirow{2}{*}{ DP } & \multicolumn{5}{|c|}{$\%$ Respostas } \\
\hline & & & 1 & 2 & 3 & 4 & 5 \\
\hline $\begin{array}{l}\text { 45. Esta organização suga a energia do funcionário, } \\
\text { obrigando-o a trabalhar um número excessivo de horas, } \\
\text { sem pagar horas-extras ou aumentar o número de } \\
\text { funcionários. }\end{array}$ & 2,76 & 1,48 & 27 & 21,6 & 18,9 & 13,5 & 18,9 \\
\hline $\begin{array}{l}\text { 46. As oportunidades de promoção e ascensão funcionais } \\
\text { oferecidas por esta organização são compatíveis com as } \\
\text { aspirações pessoais e profissionais dos funcionários. }\end{array}$ & 3,62 & 1,04 & 24,3 & 29,7 & 29,7 & 16,2 & \\
\hline $\begin{array}{l}\text { 47. Esta organização investe na capacitação e } \\
\text { aprimoramento profissional dos seus funcionários, } \\
\text { oferecendo-lhes constantemente treinamentos específicos } \\
\text { segundo a área de atuação de cada um. }\end{array}$ & 2,86 & 1,27 & 18,9 & 18,9 & 29,7 & 21,6 & 10,8 \\
\hline $\begin{array}{l}\text { 48. As recompensas financeiras pagas ao funcionário a } \\
\text { título de promoção têm valor baixo demais. }\end{array}$ & 3,11 & 0,94 & 8,1 & 8,1 & 54,1 & 24,3 & 5,4 \\
\hline $\begin{array}{l}\text { 49. Aqui, o funcionário pode opinar decisivamente na } \\
\text { resolução de problemas de trabalho. }\end{array}$ & 2,49 & 1,12 & 13,5 & 24,3 & 24,3 & 21,6 & 16,2 \\
\hline $\begin{array}{l}\text { 50. Esta organização determina prazos irrealistas para a } \\
\text { entrega de trabalhos, sem se preocupar se estão } \\
\text { disponíveis os recursos financeiros, materiais e humanos } \\
\text { necessários a sua execução. }\end{array}$ & 2,78 & 1,40 & 24,3 & 16,2 & 35,1 & 5,4 & 18,9 \\
\hline $\begin{array}{l}\text { 51. Esta organização toma as providências necessárias } \\
\text { para sanar dificuldades ou remover obstáculos ao } \\
\text { desempenho eficaz. }\end{array}$ & 3,03 & 1,04 & 8,1 & 21,6 & 35,1 & 29,7 & 5,4 \\
\hline $\begin{array}{l}\text { 52. Esta organização esforça-se para adquirir } \\
\text { equipamentos modernos de trabalho que agilizam a } \\
\text { execução das tarefas. }\end{array}$ & 3,16 & 1,12 & 8,1 & 18,9 & 32,4 & 29,7 & 10,8 \\
\hline
\end{tabular}


ANEXOS 


\section{Anexo A - Organograma do Órgão}

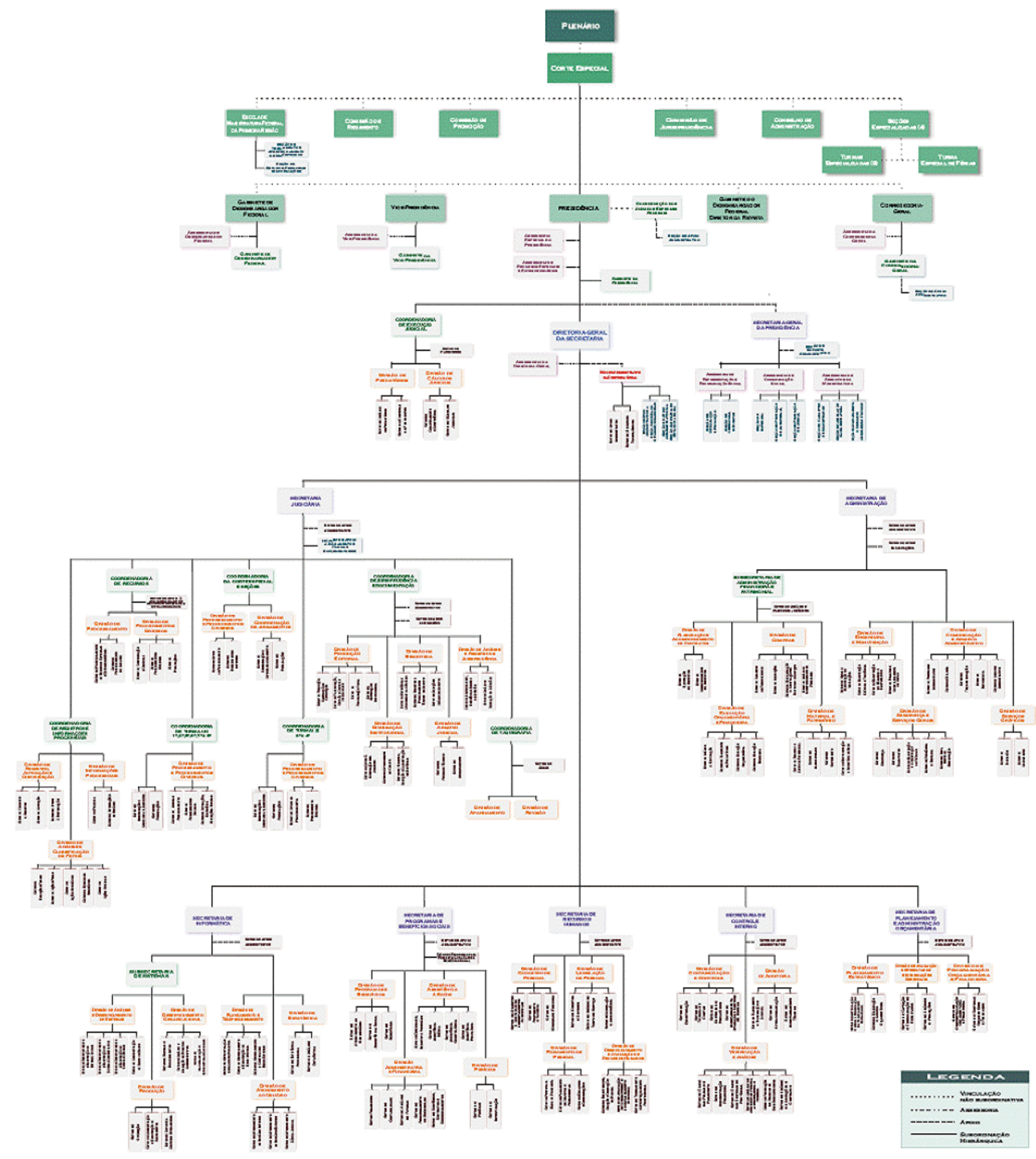


Anexo B - Orientação Geral aos Participantes da Pesquisa

\section{Orientação Geral}

Prezado (a) servidor (a),

Esta é uma pesquisa da Universidade de Brasília sobre Impacto do Treinamento no Trabalho. Para viabilizá-la procuramos a sua organização para realizar esse levantamento. Todos os funcionários que participaram do curso (nome do curso) foram solicitados a participar dessa pesquisa.

Você pode contribuir respondendo o questionário a seguir. Sua colaboração é fundamental para o sucesso deste trabalho. Você levará aproximadamente 15 minutos para responder a pesquisa

O objetivo deste estudo é avaliar o impacto do treinamento no trabalho e coletar a opinião dos treinandos sobre o suporte oferecido pela organização para a aplicação do aprendido no trabalho.

Os participantes não serão identificados e os dados fornecidos serão utilizados apenas para fins de pesquisa. Não escreva seu nome em qualquer lugar do questionário.

Por favor, responda conforme as instruções e não deixe nenhuma questão em branco.

Qualquer dúvida entre em contato com Maria Claudia Oliveira Lima via e-mail claudia.lima.m@gmail.com ou pelos telefones 8111-6201/3314-5989/3879-5491.

Agradecemos desde já a sua colaboração!

Atenciosamente, 


\section{Anexo C - Questionário de Impacto do Treinamento no Trabalho}

Neste questionário você vai encontrar questões relativas ao efeito que o treinamento provocou no seu trabalho. Para dar a sua opinião escreva nos parênteses à esquerda de cada afirmativa o quanto você concorda com ela. Para isso, utilize os seguintes códigos:

\begin{tabular}{|c|c|c|c|c|c|c|}
\hline $\mathbf{1}$ & $\mathbf{2}$ & $\mathbf{3}$ & $\mathbf{4}$ & $\mathbf{5}$ & $\mathbf{6}$ & $\mathbf{7}$ \\
\hline $\begin{array}{c}\text { Discordo } \\
\text { totalmente }\end{array}$ & Discordo & $\begin{array}{c}\text { Discordo um } \\
\text { pouco }\end{array}$ & $\begin{array}{c}\text { Não concordo, } \\
\text { nem discordo }\end{array}$ & $\begin{array}{c}\text { Concordo } \\
\text { um pouco }\end{array}$ & Concordo & $\begin{array}{c}\text { Concordo } \\
\text { totalmente }\end{array}$ \\
\hline
\end{tabular}

\section{Impacto do treinamento no trabalho}

( ) 1. Utilizo, com freqüência, em meu trabalho atual, o que foi ensinado no treinamento.

( ) 2. Aproveito as oportunidades que tenho para colocar em prática o que me foi ensinado no treinamento.

( ) 3. As habilidades que aprendi no treinamento fizeram com que eu cometesse menos erros, em meu trabalho, em atividades relacionadas ao conteúdo do treinamento.

( ) 4. Recordo-me bem dos conteúdos ensinados no treinamento.

( ) 5. Quando aplico o que aprendi no treinamento, executo meu trabalho com maior rapidez.

( ) 6. A qualidade do meu trabalho melhorou nas atividades diretamente relacionadas ao conteúdo do treinamento.

( ) 7. A qualidade do meu trabalho melhorou mesmo naquelas atividades que não pareciam estar relacionadas ao conteúdo do treinamento.

( ) 8. Minha participação no treinamento serviu para aumentar minha motivação para o trabalho.

( ) 9. Minha participação nesse treinamento aumentou minha autoconfiança. (Agora tenho mais confiança na minha capacidade de executar meu trabalho com sucesso).

( ) 10. Após minha participação no treinamento, tenho sugerido, com mais freqüência, mudanças nas rotinas de trabalho.

( ) 11. Esse treinamento que fiz tornou-me mais receptivo a mudanças no trabalho.

( ) 12. O treinamento que fiz beneficiou meus colegas de trabalho, que aprenderam comigo algumas novas habilidades. 
Anexo D - Questionário de Percepção de Suporte Organizacional

A seguir é apresentado um questionário contendo afirmativas que representam possíveis opiniões que um funcionário pode ter em relação à organização onde trabalha.

Leia atentamente o conteúdo dessas afirmativas e avalie o quanto cada uma delas descreve o que você pensa em relação a este seu local de trabalho.

Para responder cada questão, escolha o ponto da escala que melhor descreve a sua opinião conforme a quadro abaixo.

\begin{tabular}{|c|c|c|c|c|}
\hline $\mathbf{1}$ & $\mathbf{2}$ & $\mathbf{3}$ & $\mathbf{4}$ & $\mathbf{5}$ \\
\hline Discordo & $\begin{array}{c}\text { Discordo um } \\
\text { Pouco }\end{array}$ & $\begin{array}{c}\text { Não Concordo, } \\
\text { nem Discordo }\end{array}$ & $\begin{array}{c}\text { Concordo um } \\
\text { Pouco }\end{array}$ & $\begin{array}{c}\text { Concordo } \\
\text { Totalmente }\end{array}$ \\
\hline
\end{tabular}

\section{Faça um circulo em torno do número que melhor indique sua resposta em cada uma das questões.}

\section{Por favor, não deixe questões sem resposta.}

\section{Esta organização raramente fornece todos os recursos materiais necessários ao bom desempenho das tarefas.}

Nesta organização, são pouco freqüentes as manifestações de reconhecimento pelo trabalho bem feito.

$\begin{array}{lllll}1 & 2 & 3 & 4 & 5 \\ 1 & 2 & 3 & 4 & 5\end{array}$
A remuneração oferecida por esta organização permite que o funcionário desfrute a vida com dignidade.

Aqui, o funcionário sabe exatamente o que deve fazer e quais são as metas $\begin{array}{llllll}1 & 2 & 3 & 4 & 5\end{array}$ de desempenho esperadas.

Esta organização oferece locais de trabalho com móveis, equipamentos e $\quad \begin{array}{llllll}1 & 2 & 3 & 4 & 5\end{array}$ materiais em quantidade suficiente.

Esta organização valoriza novas idéias e propostas criativas de trabalho $\begin{array}{llllll}1 & 2 & 3 & 4 & 5\end{array}$ feitas pelos funcionários.

Esta organização, ao julgar o desempenho do funcionário, leva em conta o $\quad \begin{array}{lllll}1 & 2 & 3 & 4 & 5\end{array}$ esforço que ele despendeu para atingir os resultados esperados.

Aqui. O funcionário exemplar tem maiores chances do que os outros de $\quad \begin{array}{llllll}1 & 2 & 3 & 4 & 5\end{array}$ receber recompensas (como promoções, elogios certificados de merecimento e/ou similares).

Aqui, os salários pagos aos funcionários são compatíveis com os melhores $\quad \begin{array}{llllll}1 & 2 & 3 & 4 & 5\end{array}$ salários pagos no mercado para os mesmos tipos de ocupação ou cargos.

Esta organização desconsidera as sugestões de mudança e modernização $\quad \begin{array}{llllll}1 & 2 & 3 & 4 & 5\end{array}$ de procedimentos de trabalho feitas até mesmo pelo funcionário mais experiente.

Esta organização oferece um final de carreira com salários muito baixos. $\quad \begin{array}{llllll}1 & 2 & 3 & 4 & 5\end{array}$

Esta organização procura melhorar constantemente as condições físicas $\quad \begin{array}{lllllll}1 & 2 & 3 & 4 & 5\end{array}$ dos locais de trabalho.

Esta organização possui um espaço para tomar conhecimento dos problemas pessoais dos funcionários e prestar-Ihes orientação e aconselhamento. 


\begin{tabular}{|c|c|c|c|c|}
\hline $\mathbf{1}$ & $\mathbf{2}$ & $\mathbf{3}$ & $\mathbf{4}$ & $\mathbf{5}$ \\
\hline $\begin{array}{c}\text { Discordo } \\
\text { Totalmente }\end{array}$ & $\begin{array}{c}\text { Discordo um } \\
\text { Pouco }\end{array}$ & $\begin{array}{c}\text { Não Concordo, } \\
\text { nem Discordo }\end{array}$ & Concordo um Pouco & $\begin{array}{c}\text { Concordo } \\
\text { Totalmente }\end{array}$ \\
\hline
\end{tabular}

Esta organização desconsidera os interesses pessoais do funcionário, ao $\begin{array}{llllll}1 & 2 & 3 & 4 & 5\end{array}$ tomar decisões administrativas (como transferências. Por exemplo) relativas a ele.

Esta organização preocupa-se em dinamizar e modernizar constantemente $\quad \begin{array}{llllll}1 & 2 & 3 & 4 & 5\end{array}$ os processos de trabalho.

Esta organização prefere contratar pessoal externo para lidar com máquinas $\begin{array}{lllllll}1 & 2 & 3 & 4 & 5\end{array}$ ou equipamentos recém adquiridos, do que investir em treinamento dos seus funcionários para manuseá-las.

Aqui, as oportunidades de promoção e ascensão funcionais são muito raras. $\begin{array}{llllll}1 & 2 & 3 & 4 & 5\end{array}$

Esta organização preocupa-se em proporcionar o desenvolvimento das $\quad \begin{array}{lllllll}1 & 2 & 3 & 4 & 5\end{array}$ capacidades do funcionário, oferecendo-Ihe tarefas desafiadoras.

Esta organização cumpre as promessas que faz aos funcionários. $\begin{array}{lllll}1 & 2 & 3 & 4 & 5\end{array}$

Esta organização procura conhecer as dificuldades encontradas pelo funcionário no desempenho de suas atividades.

A organização esforça-se para manter os salários em patamares que permitam ao funcionário sentir menos o impacto da inflação.

Esta organização oferece todo o suporte financeiro extra necessário a execução das tarefas, tais como chamadas telefônicas de longa distancia, viagens, contratação de pessoal temporário para auxiliar no trabalho e outros.

Esta organização preocupa-se em manter seus funcionários atualizados quanto as novidades tecnológicas que afetam seu funcionário.

Esta organização chama a atenção dos funcionários por pequenas falhas ou $\begin{array}{llllll}1 & 2 & 3 & 4 & 5\end{array}$ erros, ressaltando mais os aspectos negativos do que os positivos do seu desempenho.

Nesta organização, há muitas maneiras pelas quais um funcionário pode ser $\begin{array}{llllll}1 & 2 & 3 & 4 & 5\end{array}$ promovido para cargos de melhor nível salarial (por exemplo por meio de provas de conhecimento, por avaliação de merecimento, por conclusão de cursos, etc).

Nesta organização, o funcionário recebe todas as orientações e informações $\begin{array}{lllllll}1 & 2 & 3 & 4 & 5\end{array}$ necessárias à execução eficaz das suas atividades.

$\begin{array}{llllllll}\text { Esta organização efetua regularmente a manutenção de máquinas e } & & 1 & 2 & 3 & 4 & 5\end{array}$ equipamentos de trabalho, garantindo que estejam em plenas condições de uso.

Esta organização oferece equipamentos, máquinas, materiais e $\begin{array}{lllll}1 & 2 & 3 & 4 & 5\end{array}$ equipamentos compatíveis com o nível de exigência esperado dos resultados.

Esta organização desvaloriza os esforços feitos pelos funcionários, interrompendo freqüentemente projetos de trabalho em andamento.

Aqui as ferramentas de trabalho (computadores, máquinas, etc.) são de má $\begin{array}{llllll}1 & 2 & 3 & 4 & 5\end{array}$ qualidade.

Esta organização mantém coerência entre diretrizes, discursos e ações que $\begin{array}{llllll}1 & 2 & 3 & 4 & 5\end{array}$ realiza. 


\begin{tabular}{|c|c|c|c|c|}
\hline $\mathbf{1}$ & $\mathbf{2}$ & $\mathbf{3}$ & $\mathbf{4}$ & $\mathbf{5}$ \\
\hline $\begin{array}{c}\text { Discordo } \\
\text { Totalmente }\end{array}$ & $\begin{array}{c}\text { Discordo um } \\
\text { Pouco }\end{array}$ & $\begin{array}{c}\text { Não Concordo, } \\
\text { nem Discordo }\end{array}$ & Concordo um Pouco & $\begin{array}{c}\text { Concordo } \\
\text { Totalmente }\end{array}$ \\
\hline
\end{tabular}

Aqui, os ambientes de trabalho são inadequados ao desempenho eficaz das $1 \begin{array}{llllll}1 & 2 & 3 & 4 & 5\end{array}$ atividades (salas mal iluminadas, com pouca ventilação. Pequenas demais, com móveis incompatíveis com a execução correta das tarefas, etc.)

Aqui, a carga de trabalho é excessiva, levando o funcionário ao $\begin{array}{lllll}1 & 2 & 3 & 4 & 5\end{array}$ esgotamento físico e mental.

Esta organização sobrecarrega de trabalho os seus melhores funcionários. $\begin{array}{lllllll}1 & 2 & 3 & 4 & 5\end{array}$

Esta organização e lenta demais na aquisição e na implementação do uso $\quad \begin{array}{llllll}1 & 2 & 3 & 4 & 5\end{array}$ de equipamentos de segurança no trabalho.

$\begin{array}{lllllll}\text { Esta organização deixa de oferecer cargos ou funções importantes para o } & 1 & 2 & 3 & 4 & 5\end{array}$ pessoal interno contratando pessoal externo para assumi-los.

Nesta organização, os funcionários são obrigados a fazer horas-extras constantemente, sobrando pouco tempo para estarem em casa com seus familiares.

Esta organização coloca os funcionários em locais que não se ajustam as $\begin{array}{llllll}1 & 2 & 3 & 4 & 5\end{array}$ suas características pessoais e capacidades profissionais.

Nesta organização, os recursos financeiros necessários a realização das $\begin{array}{llllll}1 & 2 & 3 & 4 & 5\end{array}$ tarefas são liberados sempre a tempo de terminar um trabalho dentro do prazo. $\begin{aligned} & \text { Esta organização consulta os funcionários antes de promover mudanças } \\ & \text { nos produtos e na organização. }\end{aligned} \quad \begin{array}{lllll}1 & 2 & 3 & 4 & 5\end{array}$

Esta organização possui um espaço para prestar orientação técnica e $\quad \begin{array}{llllll}1 & 2 & 3 & 4 & 5\end{array}$ profissional ao funcionário.

Aqui, apesar das reclamações dos funcionários, os locais de trabalho estão $\quad \begin{array}{lllll}1 & 2 & 3 & 4 & 5\end{array}$ sempre sujos.

$\begin{array}{lllllll}\text { Esta organização só se interessa pela produção deixando de oferecer } & 1 & 2 & 3 & 4 & 5\end{array}$ condições saudáveis de trabalho.

Nesta organização, falta um plano de incentivos á escolarização mediante $\begin{array}{llllll}1 & 2 & 3 & 4 & 5\end{array}$ reclassificação salarial do funcionário que conclui. com êxito, cursos que excedam a escolaridade exigida para o cargo que ocupa.

$\begin{array}{lllllll}\text { Esta organização suga a energia do funcionário, obrigando-o a trabalhar um } & 1 & 2 & 3 & 4 & 5\end{array}$ número excessivo de horas sem pagar horas-extras ou aumentar o número de funcionários.

As oportunidades de promoção e ascensão funcionais oferecidas por esta $\quad \begin{array}{llllll}1 & 2 & 3 & 4 & 5\end{array}$ organização são compatíveis com as aspirações pessoais e profissionais dos funcionários.

Esta organização investe na capacitação e aprimoramento profissional dos $\begin{array}{lllllll}1 & 2 & 3 & 4 & 5\end{array}$ seus funcionários, oferecendo-lhes constantemente treinamentos específicos segundo a área de atuação de cada um.

As recompensas financeiras pagas ao funcionário a título de promoção têm $\quad \begin{array}{lllll}1 & 2 & 3 & 4 & 5\end{array}$ valor baixo demais.

Aqui, o funcionário pode opinar decisivamente na resolução de problemas $\begin{array}{llllll}1 & 2 & 3 & 4 & 5\end{array}$ de trabalho. 
Esta organização determina prazos irrealistas para a entrega de trabalhos, sem se preocupar se estão disponíveis os recursos financeiros, materiais e humanos necessários a sua execução.

Esta organização toma as providências necessárias para sanar dificuldades $\begin{array}{llllll}1 & 2 & 3 & 4 & 5\end{array}$ ou remover obstáculos ao desempenho eficaz.

Esta organização esforça-se para adquirir equipamentos modernos de $\begin{array}{lllll}1 & 2 & 3 & 4 & 5\end{array}$ trabalho que agilizam a execução das tarefas. 